\title{
Effects of marine harmful algal blooms on bivalve cellular immunity and infectious diseases: A review
}

\author{
Lassudrie Duchesne Malwenn ${ }^{1,}{ }^{*}$, Hegaret Helene ${ }^{2}$, Wikfors Gary H ${ }^{3}$, Mirella Da Silva Patricia 4
}

1 Ifremer, LER-BO, F- 29900, Concarneau, France

2 CNRS, Univ Brest, IRD, Ifremer, LEMAR, F-29280, Plouzané, France

3 NOAA Fisheries Service, Northeast Fisheries Science Center, Milford, CT, 0640, USA

4 Laboratory of Immunology and Pathology of Invertebrates, Department of Molecular Biology, Federal

University of Paraíba (UFPB), Paraíba, Brazil

* Corresponding author: Malwenn Lassudrie Duchesne, email address : malwenn.lassudrie@ifremer.fr

\begin{abstract}
:
Bivalves were long thought to be "symptomless carriers" of marine microalgal toxins to human seafood consumers. In the past three decades, science has come to recognize that harmful algae and their toxins can be harmful to grazers, including bivalves. Indeed, studies have shown conclusively that some microalgal toxins function as active grazing deterrents. When responding to marine Harmful Algal Bloom (HAB) events, bivalves can reject toxic cells to minimize toxin and bioactive extracellular compound (BEC) exposure, or ingest and digest cells, incorporating nutritional components and toxins.
\end{abstract}

Several studies have reported modulation of bivalve hemocyte variables in response to HAB exposure. Hemocytes are specialized cells involved in many functions in bivalves, particularly in immunological defense mechanisms. Hemocytes protect tissues by engulfing or encapsulating living pathogens and repair tissue damage caused by injury, poisoning, and infections through inflammatory processes. The effects of $\mathrm{HAB}$ exposure observed on bivalve cellular immune variables have raised the question of possible effects on susceptibility to infectious disease. As science has described a previously unrecognized diversity in microalgal bioactive substances, and also found a growing list of infectious diseases in bivalves, episodic reports of interactions between harmful algae and disease in bivalves have been published. Only recently, studies directed to understand the metabolic basis of these interactions have been undertaken. This review compiles evidence from studies of harmful algal effects upon bivalve shellfish that establishes a framework for recent efforts to understand how harmful algae can alter infectious disease, and particularly the fundamental role of cellular immunity, in modulating these interactions.

Experimental studies reviewed here indicate that HABs can modulate bivalve-pathogen interactions in various ways, either by increasing bivalve susceptibility to disease or conversely by lessening infection proliferation or transmission. Alteration of immune defense and global physiological distress caused by $\mathrm{HAB}$ exposure have been the most frequent reasons identified for these effects on disease. Only few studies, however, have addressed these effects so far and a general pattern cannot be established. Other mechanisms are likely involved but are under-studied thus far and will need more attention in the future. In particular, the inhibition of bivalve filtration by HABs and direct interaction between HABs and infectious agents in the seawater likely interfere with pathogen transmission. The study of these interactions in the 
field and at the population level also are needed to establish the ecological and economical significance of the effects of HABs upon bivalve diseases. A more thorough understanding of these interactions will assist in development of more effective management of bivalve shellfisheries and aquaculture in oceans subjected to increasing $\mathrm{HAB}$ and disease pressures.

\section{Graphical abstract}

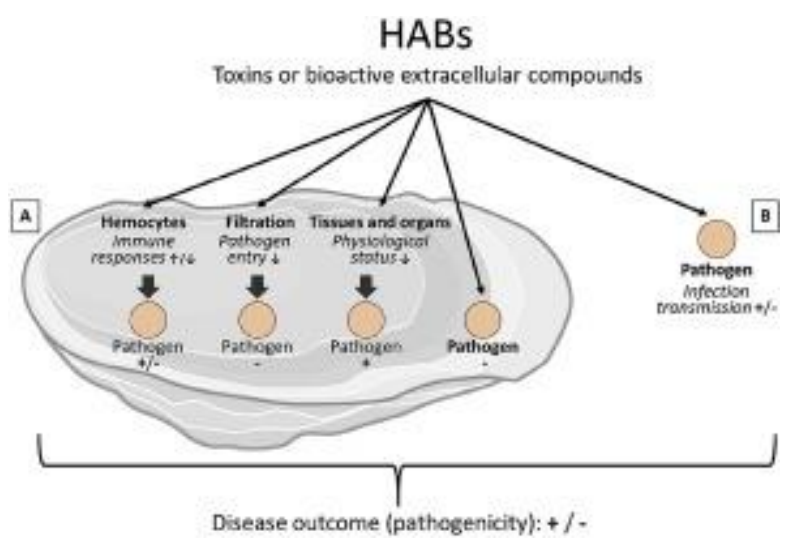

Highlights

- Review of the main studies on effects of marine harmful algae on bivalve immune cells (hemocytes) and on infectious disease. Harmful algae can modulate host-pathogen interactions in bivalves on various way (increase or decrease the infection intensity or prevalence). Some experimental studies have reported the involvement of cellular immunity and global physiological weakness in these modulations. Other mechanisms possibly involved include algal effects on bivalve filtration, and direct interaction of microalgae and their compounds with pathogens. Future research should focus on field studies, at the population level, to establish the ecological and economical significance of the effects of harmful algal blooms on bivalve diseases.

Keywords : Bivalve, Harmful Algal Blooms (HABs), Pathogen, Hemocyte, Disease 


\section{$51 \quad$ List of abbreviations}

52 ASP: amnesic shellfish poisoning

53 AZA: azaspiracids

54 AZP: azaspiracid poisoning

55 BEC: bioactive extracellular compounds

56 BRD: brown ring disease

57 CFP: ciguatera fish poisoning

58 CTX: ciguatoxin

59 DA: domoic acid

60 DHC: differential hemocyte count 
61 DMSP: dimethylsulfoniopropionate

62 DSP: diarrheic shellfish poisoning

63 DTX: dinophysistoxin

64 HAB: harmful algal bloom

65 LC: lytic compounds

66 NSP: neurotoxic shellfish poisoning

67 OA: okadaic acid

68 OIE: World Organisation for Animal Health (historically: Office International des Epizooties)

69 OsHV-1: ostreid herpesvirus-1

70 PAMP: pathogen-associated molecular pattern

71 PbTx: brevetoxin

72 PCR: polymerase chaine reaction

73 PLTX: palytoxin

74 PnTX: pinnatoxins

75 POMS: Pacific oyster mortality syndrome

76 PRP: receptor proteins

77 PSP: paralytic shellfish poisoning

78 PST: paralytic shellfish toxin

79 PTX: pectenotoxin

80 QPX disease: Quahog parasite unknown disease

81 QX disease: Queensland unknown disease

82 RLO: Rickettsia-like organisms

83 RNS: reactive nitrogen species

84 ROS: reactive oxygen species

85 SPX: spirolides

86 STX: saxitoxin

87 THC: total hemocyte count 
YTX: yessotoxin

\section{Introduction}

Bivalve fisheries and aquaculture contribute to the economy of coastal countries worldwide. Mortality from infectious disease is the main threat to this industry, and mortality can be a consequence of interacting biotic and abiotic factors. Some evidence suggests the involvement of marine Harmful Algal Blooms (HABs) in bivalve disease outbreaks, particularly through effects upon bivalve immunity and defense against disease. This contribution reviews the published literature reporting effects of marine HABs upon cellular immunity and how they relate to bivalve infectious diseases, most of which have been studied under experimental conditions. Other mechanisms possibly involved in the effects of HABs on bivalve disease also are explored.

\subsection{Bivalve diseases}

104 Bivalve populations are affected by epizootics that decimate or weaken exploited stocks and therefore limit harvests (Barbosa Solomieu et al., 2015). Commercial trade between different regions of the world contributes to exotic species introduction and, as a consequence, to the spread of infectious diseases (Andrews, 1980; Renault, 1996). Bivalve diseases are caused by

108 a variety of infectious agents (Zannella et al., 2017), mainly viruses (Arzul et al., 2017), bacteria (Travers et al., 2015), or protozoa (Robledo et al., 2014). A brief description of the most pathogenic agents for bivalves, mainly associated with OIE notifiable diseases, as well as occurrences and effects, follows.

112 In France, between 1967 and 1973, "gill disease" associated with an iridovirus, completely 113 decimated populations of Portuguese oysters Crassostrea angulata (Comps, 1988), 114 introduced from Portugal and Spain in 1868 (Marteil, 1976). This loss motivated the 115 introduction in 1971 of the Pacific oyster C. gigas from Canada and Japan (Grizel and Héral, 116 1991); Pacific oyster resistance to this virus helped revive the French oyster industry. 117 Nevertheless, in the early 1990s, Pacific oysters C. gigas were affected by "summer 
mortality" events associated with a complex interaction between temperature, genetics, and physiological status (reproductive period) of the oyster, as well as the presence of opportunistic infectious agents, such as bacteria Vibrio aesturianus and V. splendidus, and the ostreid herpesvirus-1 (OsHV-1) (Samain, 2011). In 2008, this latter virus emerged as a more powerful variant (OsHV-1 $\mu$ Var, Segarra et al., 2010), causing Pacific Oyster Mortality Syndrome (POMS), which strongly affected young C. gigas in France. POMS spread afterwards into many European countries as well as other countries in Oceania (New Zealand and Australia) (Barbosa Solomieu et al., 2015; Gittenberger et al., 2016; Mortensen et al., 2016). The OsHV-1 recently has been detected by PCR in C. gigas cultured in southern Brazil, however without any associated mortality (Mello et al., 2018), suggesting that environmental conditions can play an important role in the development of outbreaks. In Europe and Australia, Pacific oyster mortalities associated with OsHV-1 occur when temperature exceeds $16-18^{\circ} \mathrm{C}$ (de Kantzow et al., 2016; Panel and Health, 2015; Paul-Pont et al., 2014). Disbalance of environmental conditions combined with temperature stress also may contribute to the development of POMS. For example, in Australia, a POMS outbreak was correlated with heavy rainfall, presence of a pathogenic Vibrio sp., and a toxic phytoplankton bloom (Jenkins et al., 2013). In recent years, concerted efforts were made to understand the development of POMS, leading to recognition that OsHV1- $\mu$ Var could weaken oyster defenses, thereby allowing opportunisitic bacteria of the genus Vibrio to infect the host, leading to mortality (de Lorgeril et al., 2018; Petton et al., 2015).

Vibriosis is a major concern for both oyster hatcheries and field production, causing larval and spat damage, depending upon species. Vibriosis can result in impairment of velum structure and function (necrosis and detachment of velar cells) and deterioration of soft tisues, which result in mortalities (Dubert et al., 2017; Travers et al., 2015). The most pathogenic vibrios belong to the Splendidus and Harveyi clades or to the species $V$. aestuarianus, $V$. tubiashii, V. coralliilyticus, and V. tapetis (Travers et al., 2015). Although most Vibrio spp. can affect many bivalve species, $V$. tapetis appears to cause pathology only in Manila clams Ruditapes philippinarum and fishes (Levican et al., 2017; Reid et al., 2003). The resulting disease in clams is called Brown Ring Disease (BRD), because of the brown organic matrix deposit in the inner bivalve shell in responses to vibrio colonization. In advanced infections, $V$. tapetis can invade the circulatory system and lead to death (Paillard, 2004). The disease occurs in Europe, South Korea, and Japan (Travers et al., 2015). 
Two species of protozoan parasite, Marteilia refringens and Bonamia ostrea, have strongly

151 affected flat oyster Ostrea edulis production in France. M. refringens appeared in 1968

152 (Grizel et al., 1974) and B. ostreae in 1979 (Pichot et al., 1980), causing digestive gland and

153 microcell diseases, respectively. Together these parasites caused a sharp decline in flat oyster

154 production in France first, followed by in other countries in Europe (see special edition of the

155 Diseases of Aquatic Organisms journal, vol.110, 2014). Recently, B. ostrea was reported for

156 the first time in New Zealand (Lane et al., 2016). Another member of this genus, Bonamia

157 exitiosa, also caused mortalities in Ostrea chilensis in New Zealand (Hine et al., 2001) and in

158 O. puelchana from wild and cultured populations in Argentina (Oehrens Kissner et al., 2014).

159 The protozoan parasite B. exitiosa also has been reported in European flat oysters and can

160 contribute to disease (Ramilo et al., 2014). In Australia, Winter Mortality disease causes

161 mortalities in 2 and 3 year-old Sydney rock oysters Saccostrea glomerata in winter and early

162 spring (Dove et al., 2013). The disease initially was suspected to be caused exclusively by the

163 protistan parasite Bonamia roughleyi (Hill et al., 2014); however, the disease may actually

164 result from a confluence of factors, including environmental conditions (Spiers et al., 2014).

165 Another disease, called Queensland unknown (QX) disease caused by the haplosporidia 166 parasite Marteillia sydneyi, affects the S. glomerata industry in Australia (Carrasco et al., 167 2015; Perkins and Wolf, 1976). The parasite M. sydneyi enters the host by gill and palp 168 epithelia, with the progression of infection reaching the digestive tubules where parasite 169 sporulation proceeds. This process causes the breakdown of the digestive gland, 170 compromising feeding processes and leading to death (Kleeman et al., 2002).

171 Protozoan parasites from the Perkinsus genus are among the most pathogenic for oyster 172 species worldwide (Villalba et al., 2011). The first outbreak occurred in 1946 in Louisiana 173 (USA) with reported mortalities (up to 100\%) of American oysters C. virginica that resulted 174 in significant economic losses (Goulletquer et al., 1994). The disease is commonly referred to 175 as "Dermo" in reference to the belief that it was a fungus, Dermocystidium (Mackin and 176 Owen, 1950). Prevalence and body burden of Perkinsus marinus in C. virginica populations 177 in the northeastern United States present a seasonal pattern strongly related to temperature, 178 wherein maximum prevalence and intensity are reached in late summer - early automn 179 (Burreson and Ragone-Calvo, 1996). Occurrences of P. marinus in tropical regions, such as 180 Mexico (Cáceres-Martínez et al., 2016) and Brazil (da Silva et al., 2014) were reported 181 without mortalities of the native hosts, oysters $C$. corteziensis and $C$. gasar, respectively, but 182 seasonal patterns of the disease seem to be similar to those in the USA. Intensities are 
183 predominantly light to moderate, without strongly deleterious, histopathological effects

184 (Cáceres-Martínez et al., 2016; Queiroga et al., 2015; Scardua et al., 2017). Immunological 185 functions, however, were impaired in intense infections (Queiroga et al., 2013), and genetic 186 disturbances may occur because of widespread DNA methylation in C. gasar infected with 187 Perkinsus spp. (Farias et al., 2017). Another representative species of this genus is Perkinsus 188 olseni that affects clam Ruditapes descussatus and $R$. philippinarum populations in Europe 189 (Portugal, France, Spain and Italy) and Asia (South Korea and Japan). The intensity of the 190 effect of this parasite is variable, being milder in France, despite the high prevalence (up to 191 100\%) (Dang et al., 2010) and in Spain. Strong effect is observed in Portugal (Ruano et al., 192 2015), South Korea (Choi and Park, 2010) where mortalities were associated with stress of 193 high seawater temperature (Nam et al., 2018), and Japan where high prevalence (100\%) and 194 intensity were associated with declining $R$. philippinarum populations (Waki et al., 2018).

\subsection{Harmful Algal Blooms and co-occurrence with bivalve infectious diseases}

HABs are a natural phenomenon characterized by localized and transient proliferation of some microalgal species favored by certain environmental conditions (Sellner et al., 2003). The frequency of HABs appears to have increased worldwide in recent decades and may be partly related to global change and human activities (Anderson et al., 2008; Glibert, 2017; Gobler et al., 2017; Hallegraeff, 1993; Wells et al., 2015). Toxic blooms in temperate areas tend to be punctual and seasonal phenomena, most often in spring and summer, and can last a few weeks to a few months. In tropical or sub-tropical areas, blooms can last much longer where no strong seasonal environmental changes occur (e.g. blooms of Karenia brevis persisted for over a year in Florida in 2018 (HABSOS, 2019)).

The harmful effect of HABs can either be direct (toxins or damaging algal morphology) or indirect (high concentration of microalgal cells leading to hypoxia). In this paper, we will discuss only $\mathrm{HAB}$ species producing described toxins (intra- or extracellular) and other uncharacterized bioactive extracellular compounds (BEC) with cytotoxic properties, which can affect bivalves. 
212 The best-known microalgal biotoxins are those associated with symptoms in human

213 consumers of contaminated seafood (see review from Berdalet et al., 2015; Gerssen et al.,

214 2010; Lassus et al., 2016) as follows:

215 1) paralytic shellfish poisoning (PSP) is caused by saxitoxins (STXs, also refered to as 216 Paralytic Shellfish Toxins, PSTs), produced by species of Alexandrium, Gymnodinium and 217 Pyrodinium;

218 2) neurotoxic shellfish poisoning (NSP) caused by brevetoxins (PbTXs), mostly produced by 219 Karenia brevis;

220 3) diarrheic shellfish poisoning (DSP) associated with okadaic acid (OA) and 221 dinophysistoxins (DTXs) produced by species of the genera Dinophysis and Prorocentrum;

222 4) amnesic shellfish poisoning (ASP) caused by domoic acid (DA) and analogs produced by 223 species of Pseudo-nitzschia and Nitszchia;

224 5) ciguatera fish poisoning (CFP) caused by ciguatoxins (CTXs), produced by Gambierdiscus 225 species.

226 6) Other microalgal toxins implicated in human toxic symptoms include azaspiracids (AZA), mostly produced by Azadinium and Amphidoma spp. and responsible for azaspiracid poisoning (AZP); palytoxins (PLTXs) and analogues, produced by Ostreopsis spp., are associated with food-borne poisoning as well as irritative symptoms through contact or aerosol inhalation. Other phycotoxins possibly toxic to humans, as suggested by potency in 231 mouse bioassay or in vitro toxicological tests, include: spirolides (SPXs) produced by 232 Alexandrium ostenfeldii and A. peruvianum; yessotoxins (YTXs) produced by species of 233 Protoceratium, Gonyaulax and Lingulodinium; pectenotoxins (PTXs) produced by species of 234 Dinophysis; and pinnatoxins (PnTXs) produced by Vulcanodinium rugosum.

235 Other HABs, not toxic to humans but known for being deleterious to marine fauna, are 236 referred to as ichthyotoxic or fish-killing algae because they are mainly involved in mortality 237 of farmed fishes (although most also affect shellfish and other marine organisms). The 238 harmful mechanism of some of these algae is associated with hypoxia from high bloom 239 density, or through mechanical irritation, but most ichthyotoxic algae produce compounds 240 with cytotoxic and lytic activity. Some ichthyotoxins have been described already (e.g. 241 prymnesins, karlotoxins, karmitoxin), and other compounds such as reactive oxygen species 
(ROS), polyunsaturated fatty acids, and muccopolysaccharides, appear to be involved in ichthyotoxic activity (Binzer et al., 2019; Dorantes-Aranda et al., 2015; Hallegraeff et al., 2017; Rasmussen et al., 2017, 2016). Most of the algal compounds responsible for ichthyotoxic activity, however, remain unknown or not well characterized (Rasmussen et al., 2016). Algae most involved in ichthyotoxic phenomena belong to the genera Margalefidinium (aka. Cochlodinium), Chatonella, Pseudochatonella, Prymnesium, Chrysochromulina, Karenia, Karlodinium, Pfiesteria, Heterocapsa, Heterosigma, and Akashiwo (Hallegraeff et al., 2017; Lassus et al., 2016).

As sessile, filter-feeding organisms, bivalves interact directly with harmful microalgal blooms that occur along coasts worldwide. Bivalves can be in contact with both microalgal extracellular compounds, including BEC, as well as with intracellular toxins that can be released during digestion. Intracellular toxins often accumulate in bivalve tissues, mostly in the digestive gland (e.g. Lassudrie et al., 2014; Medhioub et al., 2012; see review of Landsberg, 2002). BEC have allelopathic, lytic, and oxidative activity reported upon microalgae, protists, or bivalve gametes (Arzul et al., 1999; Castrec et al., 2019; Flores et al., 2012; Le Goïc et al., 2014, 2013; Lelong et al., 2011; Long et al., 2018b; Tillmann and John, 2002). Toxins (intra- and extracellular) as well as BEC produced by HABs can be harmful to bivalves (e.g. Borcier et al., 2017; Castrec et al., 2018). HABs can affect physiological

260 functions and ultimately survival of bivalves, at different life stages, and can result in major socio-economic and ecological problems (Landsberg, 2002; Shumway, 1990).

262 Considering spatial and temporal occurrence of HABs and infectious diseases, the probability 263 for both potential stressors to affect bivalves simultaneously is high, as highlighted by Table 264 1, which lists (non-exhaustively) HABs reported to occur in regions and seasons where and when disease also occur. Only few studies, however, have reported co-occurrence of infectious disease outbreaks with HABs (Abi-Khalil et al., 2016; Jenkins et al., 2013). The

267 low number of published observations probably is attributable more to a lack of reports than a 268 lack of co-occurrence. The observations reported by these two field-studies suggested that 269 Alexandrium spp. (Abi-Khalil et al., 2016; Jenkins et al., 2013) and/or Pseudo-nitzschia spp. 270 (Jenkins et al., 2013) blooms in France and in Australia could increase oyster susceptibility to 271 POMS. As causal relationship is difficult to infer from field observations, some experimental 272 studies have focused on the interactive effects of both HABs and pathogen infection 273 (summarized in Table 2). 
274 The initial physiological status of the bivalve is one of the main conditions that modulates the

275 outcome of a host-pathogen interaction (Samain and McCombie, 2007). Thus, the physio-

276 pathological responses of bivalves exposed to both HABs and pathogens are the results of the

277 interaction between: 1) the initial physiological status of the bivalve, 2) the effect of HABs,

278 and 3) the effect of the pathogen upon the bivalve.

279 Since HABs interfere with bivalve immune cell variables and likely co-occur with disease 280 infection, we review here the effects of HABs on hemocytes, including in bivalves co281 exposed to pathogens, and their relationship with disease modulation. Other mechanisms by 282 which infectious diseases can be modulated by HABs, through alteration of bivalve 283 physiology, and through direct interactions between HABs and pathogens, are also explored.

2. Effects of HABs on bivalve cellular immunity and involvement in disease modulation

Compromised immunological status is a fundamental condition that contributes to disease acquisition and progression. Bivalve immune cells, called hemocytes, are responsive to disease infection, but can also be affected by environmental factors (e.g. temperature, salinity), including HABs. Therefore, the resulting effect on immunity and disease susceptibility has often been questioned.

In this section, after a brief description of the basics of bivalve immunity, we review the reported effects of HABs upon bivalve cellular effectors of immunity, the hemocytes, through the study of dual HAB-bivalve interactions (Table 3) and tripartite HAB-bivalve-pathogen interactions (Table 4).

\subsection{Bivalve immunity and hemocytes}

300 The immune system of bivalves is exclusively innate, lacking an adaptive memory as in 301 vertebrates, although the existence of a form of immune memory in invertebrates is now being discussed, including in bivalves (see for example Lafont et al., 2019, 2017, for C. gigas). The 
immune cells, hemocytes, are implicated in multiple physiological functions in bivalves, including nutrition, shell mineralization and tissue repair and, the most important, immunity. These circulating cells perform defense functions against infectious agents, mainly by phagocytosis or encapsulation of infective agents (Cheng, 1996). The immune systems of bivalves also include soluble molecules in the hemolymph and mucus secretions that act in the recognition and destruction or inactivation of invading organisms (Allam and Raftos, 2015; Song et al., 2010). It is now accepted that the immune system of bivalves is sophisticated and complex, presenting a high diversity of recognition molecules (Guo et al., 2015). Receptor proteins (PRPs) are inducible and secreted or are membrane proteins that recognize evolutionarily conserved pathogen-associated molecular patterns (PAMPs) (Allam and Raftos, 2015; Guo et al., 2015; Song et al., 2010). The ability to destroy microorganisms is associated with several immune molecules, including: hydrolytic enzymes, reactive oxygen and nitrogen species (ROS and RNS), and especially peptides and antimicrobial proteins which are widely studied in C. gigas (Destoumieux-Garzón et al., 2016; Schmitt et al., 2016, 2012b, 2012a). Hemocytes ontogeny, however, remains a mystery (Dyachuk, 2016; Li et al., 2017). Hemocytes circulate through the open circulatory system in the hemolymph and reach bivalve organs. Hemocytes are able to infiltrate tissues in response to infectious agents, such as bacteria and protozoa in a response termed inflammation (Carella et al., 2015; De Vico and

321 Carella, 2012), and even in some cases transiting epithelial barriers and inadvertently bringing 322 pathogens, such as $P$. marinus, inside the body (Lau et al., 2018) or expulsion of $M$. sydneyi 323 (Kleeman et al., 2002). Total (THC) and differential hemocyte counts (DHC, granulocytes and hyalinocytes, aka. agranulocytes, discriminated by cell size and internal complexity), and functional measurements, phagocytosis activity particularly, are good indicators of bivalve immune status (Fournier et al., 2000; Vargas-Albores and Barracco, 2001).

\subsection{Effects of HABs on bivalve hemocyte variables involved in immunity}

In this review we focused on the most studied bivalve hemocyte characteristics modulated by HABs or associated toxins (section 2.2), as well as by combined exposure to HAB and pathogens (section 2.3). As we focused on immunological aspects of bivalves, articles reporting genotoxic effects on hemocytes were not included in this review. The most relevant results presented in 38 articles are summarized in Table 3 and 4. 
THC, DHC, size, complexity, phagocytosis, and ROS production of circulating cells in the hemolymph are the most studied and common variables among the papers. Other hemocyte or plasma variables also were included, such as adhesion/aggregation, agglutination titer, phenoloxidase activity, viability, lysosomal membrane stability (cytotoxicity variables), and apoptosis. Apoptosis was added because programmed cell death may be particularly implicated in the immune defense against oyster intracellular pathogens (Sokolova, 2009), which has been most-thoroughly investigated in the P. marinus $-C$. virginica model (Hughes et al., 2010; Lau et al., 2018c). The studies summarized in Table 3 include the most important commercial bivalve species worldwide, i.e., oysters primarily, followed by mussels, clams, and pectinids. A good representation of HAB species is included in published studies, such as producers of PSP toxins (Alexandrium spp.), DSP toxins (Prorocentrum and Dynophysis spp.), gymnodimin (Karenia selliformis), palytoxin (Ostreopsis ovata), karlotoxins (Karlodinium veneficum), and other toxic compounds still not well characterized from Karenia mikimotoi, Heterosigma akashiwo, and Heterocapsa circularisquama. The effects of purified phycotoxins were evaluated by in vitro incubation with hemocytes (STX, OA and $\mathrm{PbTx}$ ) or by injection into the living bivalve (DA). No studies on hemocyte responses were carried out with algal producers of DA, YTX, CTX, or AZA toxins thus far (Table 3).

Bivalve hemocyte responses to a harmful alga depend upon the physiological state of the bivalve, but also on algal morphology and density, intraspecific variability of algal toxicity, and experimental conditions, which altogether may affect exposure to algal compounds, including through pre-and post-ingestive selection. Therefore, it is sometimes difficult to identify similar hemocyte response patterns, even considering the same alga and bivalve species. Two good examples of diversity of bivalve responses were obtained with the moststudied harmful algae $A$. minutum and $P$. minimum. In one experiment exposing $C$. gigas to $A$. minutum, only an increase in hemocyte phagocytosis was observed (Haberkorn et al., 2014). In contrast, in another study, THC and granulocytes increased and ROS production and phenoloxidase activity were not consistent (Haberkorn et al., 2010a). Regarding P . minimum, in one study, a simulated bloom increased $C$. virginica hemocyte phagocytosis, THC, granulocyte counts and viability, and aggregation decreased, while ROS varied (Hégaret and Wikfors, 2005a); whereas, the other experiment did not promote any hemocyte modulation

364 (Hégaret and Wikfors, 2005b). Difference in hemocyte responses in these studies were attributed to differences between oyster populations and the means of algal exposure, i.e., 
cultured cells or a natural bloom. The latter study was later corroborated by an in vitro assay (Hégaret et al., 2011).

368

The species A.catenella (=A. fundyense as refered to in these studies; see last nomenclature in Fraga et al. 2015; Litaker et al. 2018) caused only mild effects upon hemocytes of adult $C$. virginica and C. gigas (Hégaret et al., 2007b) and M. edulis (Galimany et al., 2008b). In contrast, A. catenella and A. tamarense caused cytotoxic effects in addition to impairment of immune responses in blue mussels M. edulis (Bianchi et al., 2019). Cytotoxic effects, however, were not directly related to PSTs. Indeed, both PST and non-PST strains that produced BEC (also refered to as lytic compounds, LC), caused similar responses (Bianchi et al., 2019). Similarly, a highly-toxic, PST-producing strain of A. catenella (named A. tamarense in the study; see new nomenclature in John et al., 2014; Fraga et al., 2015; Litaker et al., 2018) had no effects upon $R$. philippinarum or $M$. arenaria hemocytes; whereas, a nonPST strain of A. tamarense did have effects, probably caused by bioactive compounds (Ford et al., 2008). Castrec et al. (2018) compared the effects of three A. minutum strains with contrasting PST and BEC characteristics. This study detected clear effects of PST on hemocyte mortality, hypothesized to involve apoptosis. PST effects upon hemocyte apoptosis were reported previously from in vivo (PST injection) and in vitro (PST exposure of hemocytes) assays with lions-paw scallops Nodipecten subnodosus (Estrada et al., 2014), in C. gigas, in vivo (A. pacificum exposure) (Medhioub et al., 2013), and in vitro (PST exposure of hemocytes) (Abi-Khalil et al., 2017). In other work with A. minutum and C. gigas, using in vitro exposures, similar responses, phagocytosis and ROS inhibition, were observed when hemocytes were exposed to PST-producing strains of Alexandrium spp. or directly to PSTs (Hégaret et al., 2011; Mello et al., 2013). The effects of PSTs themselves upon hemocytes seem to be relatively consistent, reducing phagocytosis (Astuya et al., 2015; Cao et al., 2018; Mello et al., 2013) and ROS (Astuya et al., 2015; Mello et al., 2013), regardless of bivalve species and administration mode (direct exposure or injection).

Separating effects of intracellular toxins and BEC has been recognized only recently because of a lack of awareness of the existence of BEC, and for practical reasons (availability of algal strains with different toxin and BEC characteristics). Correlations between hemocyte variables and toxin accumulation in tissues indicated that specific hemocyte responses to PST occur in C. gigas exposed to Alexandrium spp. (Haberkorn et al., 2010a; Lassudrie et al., 2016). This was later confirmed using different A. minutum strains with contrasting PST and BEC characteristics, showing some distinct hemocyte responses to PST vs. BEC (Bianchi et 
al., 2019; Castrec et al., 2018). Results of Lassudrie et al.(2016) with the oyster C. gigas

400

401

402

403

404

405

406

407

408

409

410

411

412

413

414

415

416

417

418

419

420

421

422

423

424

425

426

427

428

429

430

431 exposed to A. pacificum (named A. catenella, in this study; see last nomenclature in John et al. 2014; Fraga et al. 2015; Litaker et al. 2018) indicated a relationship between PST levels and hyalinocyte variables, suggesting a particular role for this hemocyte type in response to PST; whereas, granulocyte modulations may respond to putative BEC. Other studies with $A$. minutum, however, did not support the hypothesis of a specific role of hyalinocytes in PST response (Castrec et al., 2018; Haberkorn et al., 2010a). Further studies are needed to decipher the functional responses of the different hemocyte types to PST vs. other bioactive compounds.

The toxic dinoflagellate $P$. minimum was also reported to have different effects upon $C$. virginica (Hégaret and Wikfors, 2005a, 2005b). Results of some experiments indicated increased phagocytosis and decreased aggregation and mortality (Hégaret and Wikfors, 2005a), other experiments did not detect any alteration in hemocyte variables (Hégaret and Wikfors, 2005b). A decrease of phagocytosis and of apoptosic hemocytes could be observed in clams $R$. philippinarum exposed to P. minumum (Hégaret et al., 2009). However, no effect on hemocyte was observed also in M. edulis exposed to P. minimum, (Galimany et al., 2008c). In contrast, a simulated bloom of $P$. minimum strongly affected all hemocyte variables of scallops A. irradians irradians (Hégaret and Wikfors, 2005b). This could indicate a higher sensivity of scallops to some HABs like $P$. minimum than other bivalves, such as $C$. virginica. More studies are needed to support this hypothesis. The dinoflagellate $P$. lima and associated OA toxin were tested against mussels and clams and were shown to induce hemocyte apoptosis (Prado-Alvarez et al., 2013; Prego-Faraldo et al., 2016, 2015), except in one case of a natural bloom of Prorocentrum sp. and Dinophysis sp., and OA in vitro exposure (PradoAlvarez et al., 2012). Effects of a simulated bloom of $P$. lima upon hemocyte functions were tested recently in the mussel Perna perna, and impaired phagocytosis, induced ROS production, and decreased THC were observed (Neves et al., 2019).

Although simulating a HAB under laboratory conditions may be a good approximation of reality, it is unquestionable that the best way to evaluate $\mathrm{HAB}$ effects upon bivalve cellular immune functions will be during a natural bloom; however, only three studies were conducted under those circumstances (Mello et al., 2010; Prado-Alvarez et al., 2012; Simões et al., 2015). During a natural bloom of Dinophysis acuminata in Santa Catarina state, South Brazil, some immune responses of three bivalve species belonging to different families were studied (Table 3). A reference group, animals collected at same site 30 days after the HAB exposure, 
were used for comparisons. Despite the differences in the concentration of algae during the blooms, it was clear that the bivalve species responded differently, $C$. gigas was the most resilient species; whereas, the mussel $P$. perna was the most affected, suggesting that this mussel may be a good bioindicator species. The sentinel candidature of mussels for environmental change and now for HABs was corroborated in another study with the mussel M. galloprovinciallis exposed to the bentic dinoflagellate Ostreopsis cf. ovata with strong impairment (reduction) in granulocyte counts, phagocytosis activity, and lysosomal membrane stability as cytotoxic effects (Gorbi et al., 2013). In contrast, a study exposing oyster $C$. gigas hemocytes to brevetoxin did not reveal any cytotoxic effect (viability and apoptosis were evaluated) (Mello et al., 2012). Even though no Pseudo-nitzschia or Nitszchia spp. blooms have been evaluated for effects upon immune cellular responses of bivalves, $M$. edulis was exposed to DA by intra-muscular injection (Dizer et al., 2001). The acute effects of DA were seen in THC and phagocytosis, which increased initially, but after 7 days postinjection, variables normalized and hemocyte viability increased in a dose dependent manner during recovery.

\subsection{Involvement of HAB effects on bivalve hemocytes in disease modulation?}

The several effects of HABs upon hemocyte variables documented above led many authors to wonder about $\mathrm{HAB}$ effects upon immune functions and eventually upon disease susceptibility. These effects upon hemocytes have been hypothesized to modify the efficiency of bivalve immune functions, either by causing immunosuppression, particularly when functions such as phagocytosis are affected, or immunostimulation when considering increased THC or viability, for example. Few papers, however, report the combined effects of HABs and infectious agents upon immune functions of bivalves (Table 4). Most studied is the host-parasite model $R$. philippinarum-P. olseni under the secondary effect of HABs $K$. selliformis and K. mikimotoi (da Silva et al., 2008; Hégaret et al., 2007a), P. minimum (Hégaret et al., 2009) and A. ostenfeldii (Lassudrie et al., 2014). Others evaluated the effects of HAB A. catenella (=A. fundyense), on P. marinus and Bucephalus sp. in oysters $C$. virginica (Lassudrie et al., 2015b), on trematodes Gymnophalidae in mussels M. edulis (Galimany et al., 2008b), on BRD caused by $V$. tapetis in clams $R$. philippinarum (Bricelj et al., 2011). The effect of P. minimum on Quahog Parasite Unknown (QPX) disease in clams M. mercenaria also was studied (Hégaret et al., 2010). 
Many of these studies reported a repression of hemocyte responses during the interaction of bivalve - pathogen - HAB, which cannot be explained simply. Indeed, the combination of the two biotic factors causes hemocyte responses that might not correspond to the cumulative effect of each isolated factor, leading to antagonistic or synergistic responses. Additionally, the existence of combined effects of HAB and pathogen can modulate the bivalve response. For example $K$. selliformis, in a short exposure experiment, inhibited $R$. philippinarum hemocyte phagocytosis and increased hemocyte count in clams heavily infected with $P$. olseni; whereas, the parasite itself did not affect the host (Hégaret et al., 2007a). Another toxic dinoflagellate, A. ostenfeldii had a very mild effect itself upon $R$. philippinarum hemocyte variables, but the combination with $P$. olseni infection induced ROS production in lightlyinfected clams comparable with the levels found in the heavily-infected animals unexposed to HAB (Lassudrie et al., 2014). Likely, the interference between hemocyte responses to HAB and to pathogens are related to different functions.

477 It was hypothesized initially that effects of HABs upon hemocyte functionality would induce an immunocompromised state associated with increased susceptibility to disease. Such immunodepression, indicated by immunological changes and inflammatory response, was hypothesized by Galimany et al. (2008c) after observation of increased prevalence of trematodes in mussels exposed to $A$. catenella ( $=A$. fundyense). Increase in parasite $P$. marinus prevalence was detected in the Eastern oysters exposed to A. catenella and concomitantly infected by trematodes Bucephalus sp. (Lassudrie et al., 2015b). This increase

484 in parasite prevalence was associated with repression of hemocyte responses to the trematode 485 infestation (Lassudrie et al., 2015b). The authors concluded that this higher susceptibility to $P$. marinus was likely the result of immunosuppression caused by HAB exposure in oysters already weakened by trematode infestation, as indicated by histological evidence.

488 Other studies reviewed in Table 4 could not link the hemocyte alteration caused by HABs 489 with disease modulation. 
HAB exposure can affect several physiological variables in bivalves. Here, we discuss the variables most likely involved in disease transmission or proliferation that have been reported to be modulated by HABs: feeding activity, and tissue alterations, often associated with inflammatory response.

3.1 Effects of HABs on feeding processes: possible involvement in pathogen transmission?

502 Filtration and ingestion rates could play an important role in the modulation of the tripartite interactions. Indeed, infection process is deeply related to the entry of pathogenic agents into the bivalve body. Thus, it can be speculated that the lower the filtration rate, the lower the level of parasite inside the host.

Bivalves have the ability to adapt filtration and ingestion rates (feeding activity) to plankton composition. Indeed, decreases in clearance and filtration rates of several bivalve species in the presence of toxic microalgae have been widely reported in the literature (e.g. Contreras et al., 2011; Hégaret et al., 2007c; Jauffrais et al., 2012; Lassus et al., 2007, 1999; Shumway, 1990).

511 In oysters, reduction of A. minutum consumption seems to be mostly associated with algal 512 BEC production, rather than to PST (Castrec et al., 2018). BECs irritate gills and, therefore,

513 likely interfere with filtration or sorting functions and induce a protective behavioral response 514 consisting of increased frequency of valve micro-closures (Castrec et al., 2018; Haberkorn et 515 al., 2011; Tran et al., 2010). Conversely, contact with intracellular PSTs occurs mainly in the 516 digestive organs after algal cell lysis. Pousse et al. (2018), however, demonstrated that a PST, 517 non-BEC-producing strain of A. minutum also caused a decrease in feeding activity, thus 518 suggesting the involvement of PST in filtration response. Furthermore, a recent study 519 exposing mussels to Alexandrium spp. strains with different PST and BEC characteristics, 520 also suggested that PSTs cause lower feeding activity (Bianchi et al., 2019). Such differences 
may, indeed, be caused by variability in both BEC and PST quality and quantity exposure in the two studies, or to different sensitivity of mussels and oysters.

523

Reduction in herpesvirus infection, associated with POMS, in juvenile $C$. gigas oysters was hypothesized to be associated with filtration decrease (Lassudrie et al., 2015a). No study to date, however, has investigated the specific links between effects of HABs upon feeding processes and infectious agent transmission and proliferation.

\subsection{Tissue degeneration and inflammatory response caused by HABs: overall physiological weakness favorizing disease susceptibility?}

Despite the ability of bivalves to avoid or reduce ingestion of some HAB species, they show histopathological effects resulting from the HAB exposures.

The most common tissues affected are epithelia from mantle, gills, digestive gland or foot, and the most common alterations found are: vacuolation, oedema, melanization of gills and mantle (putatively associated with oxidative stress), signs of irritation (mucus production), and digestive tubules sloughing and atrophy (Haberkorn et al., 2010b; Hégaret et al., 2012, 2010, 2009; Lassudrie et al., 2014; Medhioub et al., 2012; Neves et al., 2019). Depending upon the organ, effects upon epithelia can be attributed to: (a) the extracellular compounds released by $\mathrm{HABs}$, and (b) the intracellular toxins released after cell lysis at the end of the bloom or after direct contact with gills, or as a consequence of digestion. Indeed, the digestive gland is the organ accumulating most of the algal intracellular toxins (e.g. Lassudrie et al., 2014; Medhioub et al., 2012; see review of Landsberg, 2002).

Additionally, exposure to PST-producing HABs, or to purified toxins, can affect muscle integrity (Estrada et al., 2010; Haberkorn et al., 2010b; Hégaret et al., 2012, 2009), sometimes associated with altered escape response (Hégaret et al., 2012) or paralysis (Estrada et al., 2010).

Inflammatory response, consisting of hemocyte infiltration, often is observed in response to $\mathrm{HAB}$ or associated toxin exposure and likely is involved in repairing damaged tissues (e.g. Estrada et al., 2010; Hégaret et al., 2010; Hermabessiere et al., 2016; Lassudrie et al., 2015b, 2014; Medhioub et al., 2012). Hemocyte diapedesis through the digestive epithelia, and significative presence of hemocytes in the lumen of the intestine or around the gills, 
surrounding algal cells, and in the faeces, also suggest a mechanism comparable to encapsulation to protect the internal tissues from algal toxic compounds (Galimany et al., 2008c; Hégaret et al., 2009). These observations also lead some authors to assume an additional role for hemocytes in detoxification, i.e., transporting toxins or their products outside the tissues (Galimany et al., 2008c, 2008b; Hégaret et al., 2009). Detection of a type of lipohphilic algal toxin, yessotoxins, in the hemocytes of mussels (Franchini et al., 2003), supports this hypothesis.

Degeneration of tissues and inflammatory response caused by HAB exposure are likely to increase susceptibility to pathogens by physiologically weakening bivalves and possibly interfering with hemocyte immune functions by recruiting hemocytes for tissue repair. This mechanism was suggested previously by Hégaret et al. (2012) and Lassudrie et al. (2015a) who observed concomitant tissue alterations and disease modulation under $\mathrm{HAB}$ exposure (Table 2).

\section{Modulation of bivalve disease through direct effect of HABs on}

\section{infectious agents}

Direct interactions between HABs and infectious agents in the environment may affect bivalves indirectly by interfering with infectious agent transmission or proliferation. Two possible types of interactions are considered here: (a) effects of algal toxins and extracellular compounds on bivalve pathogens, which could either be beneficial or deleterious to pathogens, and (b) the possibility of microalgae, including HABs, to act as pathogen carriers.

\subsection{Effects of algal toxins and extracellular compounds to bivalve pathogens}

575 Bivalve pathogens may be in contact with toxic algal cells and associated toxic compounds

576 directly before infecting the host (dissolved toxins or BEC) or during infection, within bivalve 577 tissues (BEC or accumulated toxins).

578 Efforts to characterize the deleterious effects of extracellular compounds from HAB species 579 upon various microorganisms have highlighted cytotoxic activity towards auto- and hetero- 
trophic protists (Adolf et al., 2007; Arzul et al., 1999; Flores et al., 2012; Lelong et al., 2011; Long et al., 2018b, 2018a; Tillmann, 2003; Tillmann et al., 2008; Tillmann and John, 2002). As many species of HABs are mixotrophic, but also serve as prey, such extracellular bioactivity is believed to be related to predation and/or defense (anti-grazing) behavior (e.g. Adolf et al., 2007; Tillmann, 2003; Tillmann et al., 2008). Similarly, many other microalgae, including HAB species, can also feed on bacteria (Burkholder et al., 2008; Mitra et al., 2014).

Effects of HABs specifically upon protists, bacteria, and viruses pathogenic to bivalves have rarely been investigated (Table 2). Reports of decreased infections suggest that HABs could alter viability or virulence of bivalve pathogens (see further examples below, in da Silva et al., 2008; Hégaret et al., 2010; Lassudrie et al., 2015a). Another scenario considered is that HAB compounds could promote growth of pathogenic bacteria, as bacteria can consume organic nutrients excreted by microalgae (Seymour et al., 2017; Zhou et al., 2018). Among compounds excreted by microalgae, dimethylsulfoniopropionate (DMSP) is an organosulfur compound that is a potent chemoattractant to bacteria, which can metabolize it and use it as carbon and sulfur sources (Kiene et al., 2000; Simó, 2001). Not incidentally, harmful algal species are mostly represented by dinoflagellates, which are important DMSP producers among phytoplankton groups (Caruana and Malin, 2014).

Many studies reported the allelopathic, lytic, and oxidative properties of Alexandrium spp. extracellular compounds toward different cells, such as microalgae, protists, or bivalve gametes (Arzul et al., 1999; Castrec et al., 2019; Flores et al., 2012; Le Goïc et al., 2014, 2013; Lelong et al., 2011; Long et al., 2018b; Tillmann and John, 2002). Although PST can be released extracellularly (Lefebvre et al., 2008; Persson et al., 2012), many studies reported the bioactivity of extracellular compounds produced by non-PST Alexandrium strains, demonstrating that these effects are independent from PSTs (Bianchi et al., 2019; Borcier et al., 2017; Castrec et al., 2019, 2020; Ford et al., 2008; Long et al., 2018b; Tillmann et al., 2007; Tillmann and John, 2002). Only a few studies focused on the characterization of these compounds, and their precise nature remains unknown (Flores et al., 2012; Ma et al., 2011, 2009).

Antibacterial compounds produced by microalgae have been widely reported in the literature (see for example Amaro et al., 2011; Kellam and Walker, 1989), including upon bacteria pathogenic to aquacultured species, in particular Vibrio spp. (Kokou et al., 2012). Antibacterial effects of HAB species, however, have rarely been studied. Lauritano et al. 
612 (2016) did not detect any activity of intracellular extracts of Pseudo-nitzschia

613 pseudodelicatissima, Alexandrium tamutum, A. andersonii and A. minutum against different

614 Gram-negative and Gram-positive bacteria infecting humans. PSTs target voltage-gated

615 sodium channel receptors, resulting in modulations of sodium and potassium fluxes in many

616 organisms, such as mammals (Catterall, 2000), bivalves (Boullot et al., 2017), and certain

617 bacteria (Pomati et al., 2003). Such effects were also demonstrated in the bacterium Vibrio

618 fischeri (Pomati et al., 2003). Therefore, it could be hypothesized that PST released by algal

619 cells may interact with certain pathogenic bacteria in situ and result in modulation of infection

620 in bivalves, although no study has demonstrated such effects so far.

621 Extracellular compounds from microalgae, including recognized HAB species, can have 622 antiviral activity (see review by Amaro et al., 2011). For example, extracellular sulphated 623 polysaccharides produced by Gymnodinium impudicum and Margalefidinium polykrikoides 624 were reported to affect viruses pathogenic to human and other mammalian hosts (Hasui et al., 625 1995; Yim et al., 2004). The observation of a decrease in intensity of herpesvirus OsHV$6261 \mu$ Var infection in juvenile oysters $C$. gigas exposed experimentally to A. pacificum led the 627 authors to propose that the dinoflagellate extracellular compounds may also induce deleterious effects in viruses (Lassudrie et al., 2015a). The hypothesis was advanced that ROS produced in extracellular compounds of Alexandrium spp. (as evidenced by Flores et al., 2012) could have altered the OsHV-1 lipidic envelope and thereby infectivity. Despite these hypotheses, no study so far has confirmed the direct effects of HABs upon viruses pathogenic 632 to bivalves.

633 Deleterious effects of other dinoflagellates upon bivalve parasites were reported. An in vitro 634 experiment reported toxicity of a culture of $K$. selliformis to the Manila clam parasite $P$. 635 olseni, as indicated by observation of a higher percentage of dead P. olseni cells and altered 636 morphology (da Silva et al., 2008). These effects were believed to be responsible for 637 decreasing intensity of $P$. olseni infection in clams $R$. philippinarum exposed experimentally 638 to this alga (da Silva et al., 2008). Similarly, Hégaret et al. (2009) reported toxic effects of 639 extracellular compounds from $P$. minimum to $P$. olseni cells during an in vitro experiment. 640 These authors, however, did not observe any modulation of the $P$. olseni infection in Manila 641 clams exposed to this alga, possibly because of the short duration of the exposure (6 days) 642 (Hégaret et al., 2009). 
643 Exposure to HABs were reported to modulate disease infections in bivalve, but only few

644 studies have focused on the direct interaction between HABs and pathogenic agents so far

645 (Table 2). Additional, in vitro exposures of pathogenic microorganisms to toxic microalgae

646 and associated compounds are needed to better understand how microalgal extracellular 647 compounds can alter bivalve infectious agent viability or virulence. Such methods, however, 648 are limited by the inability to cultivate several pathogenic agents without the host 649 (herpesvirus, certain bacteria and parasites). Field studies and developments in environmental 650 DNA analyses may overcome this limitation.

651

$652 \quad 4.2$ Microalgae as vectors of infectious agents?

653 Phytoplankton dynamics may participate in disease transmission in bivalves as infectious 654 agents may be attached to planktonic food particles. For example, viral particles of OsHV-1 655 were reported to attach to particles in situ, including algal food particles, leading the authors 656 to hypothesize that plankton dynamics plays a key role in POMS transmission (Evans et al., 657 2015, 2014; Paul-Pont et al., 2013). Similarly, the acute viral necrobiotic disease virus, 658 pathogen to the scallop Chlamys farreri, was shown to be carried by microalgae (Zhang et al., 659 2010).

660 Toxic dinoflagellates were reported to be vectors of human infectious agents, such as 661 Legionella pneumophila or Vibrio cholerae (see review of Doucette, 1995; Rivera et al., 662 2013). No published study has researched so far the specific ability of toxic dinoflagellates to 663 transport and disseminate bivalve pathogenic agents. The hypothesis of toxic microalgae 664 acting as vectors for bivalve pathogenic agents could be further investigated to explore these 665 phenomena.

\section{Discussion and future research recommendations}

670 This review, mainly based upon experimental studies, highlighted that HABs can modify 671 disease processes in bivalves through several mechanisms (summarized in Figure 1). 672 Modulation of hemocyte immune functions by HABs and associated compounds is one 
673

674

675

676

677

678

679

680

681

682

683

684

685

686

687

688

689

690

691

692

693

694

695

696

697

698

699

700

701

702

703

reported mechanism leading to the effects of HABs on disease in bivalves. HAB exposure can cause immunosuppression that promotes pathogen proliferation. Conversely, HAB exposure could stimulate immune responses. However, other mechanisms are likely involved, but are under-studied thus far, and need more attention in the future. Indeed, HAB exposure can decrease bivalve filtration rate, which may in turn decrease pathogen acquisition. HABs can also cause tissue and organ lesions, increasing bivalve global physiological weakness and decreasing defense against pathogens. Pathogen viability or pathogenicity can be affected directly by $\mathrm{HAB}$ toxins or compounds in the seawater, which suggest they could also be affected in bivalve tissues exposed to HAB compounds. Finally, HABs could act as pathogen carriers and favor pathogen transmission.

Modulation of pathological condition in bivalves exposed to HABs and pathogens is the result of the interaction between the initial physiological status of the bivalve, the effects of the HABs, and the effects of the pathogen. It is challenging, therefore, to identify unique mechanisms applicable to all bivalves, and conclusions should be made for each bivalve population of interest and the specific HAB-pathogen combination. To best address a specific situation, we recommend experimental studies that simulate as close as possible the natural conditions. For example, experiments should be consistent with the seasonality of HABs and pathogen appearance in the field. To better understand the mechanisms involved, and for purposes of comparison with other studies, extensive information should be provided regarding the bivalve initial condition (reproduction stage, age, origin, etc), and the HABs and pathogens (strain information, origin, growing conditions and stage, toxin production, etc) studied.

The ecological and economical significance of the effects of HABs upon bivalve disease are not well established, although experiments have shown clearly that such effects are likely. The study of these interactions in the field, and at the population level, is now needed to answer these questions.

The experimental studies and the field observations reported here only consider the immediate effects of a $\mathrm{HAB}$ exposure upon pathogen infections. Whether these acute effects can durably affect the dynamics of the host-pathogen interaction is a question that remains to be answered. From a selected number of HAB-bivalve-pathogen interaction studies reviewed herein, 
conceptual models of evolution of the host-pathogen dynamics can be proposed (Figure 2). We propose that the effect of a $\mathrm{HAB}$ on bivalve infectious disease would depend upon the temporal dynamics of both the disease and the HAB.

707 In the studies reviewed here, bacterial and viral infections led to rapid and intense consequences, i.e., acute effects (Figure 2A, B). POMS in France induces each year a mortality peak over a few weeks in oyster $C$. gigas spat. This disease is associated with herpesvirus and/or bacteria such as $V$. tasmaniensis. Lassudrie et al. (2015a) showed experimentally that a bloom of A. pacificum starting before herpesvirus exposure could alter transmission or proliferation of the virus. Conversely, Abi-Khalil et al. (2016) experimental results indicated that an A. pacificum bloom starting before injection of $V$. tasmaniensis could increase oyster mortality induced by the infection. These two experimental studies suggest that at the population level, mortality events could be modulated by toxic blooms occuring before the outbreak (Figure 2A, B).

Other papers reviewed here studied the effects of HABs on diseases associated with parasites P. olseni (da Silva et al., 2008; Lassudrie et al., 2014), P. marinus (Lassudrie et al., 2015b) and bacteria RLO (Rickettsia-like organisms; Hégaret et al., 2012). In the bivalve populations studied, these diseases do not induce severe mortality, resulting in long-lasting host-pathogen interactions. In the short-term, a toxic bloom can modulate the development of a bacterial (Hégaret et al., 2012) or parasitic (da Silva et al. 2008; Lassudrie et al., 2015b) infections (Figure 2C, D). Specifically, Lassudrie et al. (2015b) results indicated that an A. catenella (= A. fundyense) bloom could promote $P$. marinus infection in oysters $C$. virginica that were already weakened by trematode infestation. The parasitic levels were not surveyed after the toxic algal exposure, it is therefore questionable wether this HAB would durably disrupt the $P$. marinus - C. virginica interaction, or wether the initial $P$. marinus levels would be quickly restored (Figure 2C). Nevertheless, it does not seem realistic that a short-term HAB exposure could have a long-term consequence. The equilibrium of the host-pathogen interaction would probably recover after exposure, as suggested by the results of da Silva et al. (2008) (Figure 2D). In this study, the intensity of infection by P. olseni in clams R. philippinarum decreased after 2 and 3 weeks of exposure of toxic dinoflagellate $K$. selliformis. Then, after 3 weeks of exposure at a lower K. selliformis concentration, the intensity of infection was restored to its original level (Figure 2D). 
Another point to consider is that HABs are usually recurrent phenomena, whereas most studies assess the effect of a single HAB exposure. Long-term effects of repeated toxic blooms upon host-pathogen interaction dynamics at the population level should therefore be considered. Effects of HABs upon bivalve reproduction and on physiology through parental exposure were reported recently (e.g. Basti et al., 2013; Castrec et al., 2019, 2020; Rolton et al., 2015), and could ultimately alter bivalve population fitness in the case of repeated blooms. Adaptations of bivalve populations to recurrent toxic blooms, reflected by differential physiological responses between populations (Navarro et al., 2014), can lead to the emergence of resistant genotypes (Bricelj et al., 2010, 2005). The use of in situ monitoring and epidemiological models could contribute to understanding of effects of HABs upon the hostpathogen interactions at the population level.

Climate change conditions have been reported experimentally to alter physiology of bivalves and interaction with HABs (Farrell et al., 2015; Turner et al., 2016). Therefore, the HABbivalve-pathogen interaction likely will evolve under future climate conditions.

\section{Conclusion}

Increased disease susceptibility in bivalves caused by HAB exposure has been related to altered immune functions and global physiological distress. This pattern, however, is not always verified, as direct deleterious effects of HABs upon certain pathogenic agents can result in lower pathogen infection. Other processes likely interfere with disease infection under $\mathrm{HAB}$ exposure, such as filtration and direct interactions between pathogens and HABs. More studies are needed to understand the role of these processes in the complex tripartite bivalve-pathogen-HAB interaction. Future research should also focus on field observations to verify experimental results, and to identify the effect of HABs upon disease dynamics at the bivalve population level. Such considerations may provide clues for unexplained mortalities, and eventually improve shellfish management.

\section{Declaration of interest}


Nothing to declare.

\section{Acknowledgments}

770
The authors wish to thank Philippe Soudant and Caroline Fabioux (LEMAR, France) for their contribution to the first document in ML Ph.D. thesis that set the frame years ago for this review, and Raquel A. F. Neves (Universidade Federal do Estado do Rio de Janeiro, Brazil) for her help with listing HAB species from Brazil. Fundings from the PADDLE project (funding by the European Union's Horizon 2020 research and innovation program-grant agreement no. 73427) and from the French National program EC2CO (Ecosphère Continentale et Côtière, LET IT BI project) enabled to collaborate on this manuscript.

\section{References}

Abi-Khalil, C., Finkelstein, D.S., Conejero, G., Du Bois, J., Destoumieux-Garzon, D., Rolland, J.L., 2017. The paralytic shellfish toxin, saxitoxin, enters the cytoplasm and induces apoptosis of oyster immune cells through a caspase-dependent pathway. Aquat. Toxicol. 190, 133-141. https://doi.org/10.1016/j.aquatox.2017.07.001

Abi-Khalil, C., Lopez-Joven, C., Abadie, E., Savar, V., Amzil, Z., Laabir, M., Rolland, J.-L., 2016. Exposure to the Paralytic Shellfish Toxin Producer Alexandrium catenella Increases the Susceptibility of the Oyster Crassostrea gigas to Pathogenic Vibrios. Toxins (Basel). 8, 24. https://doi.org/10.3390/toxins8010024

Adlard, R.D., Wesche, S.J., 2005. Aquatic Animal Health Subprogram: development of a disease zoning policy for Marteilia sydneyi to support sustainable production, health certification and trade in the Sydney rock oyster, in: Fisheries Research and Development Corporation Final Report 2001-214. South Brisbane, Australia: Queensland Museum, Brisbane, p. 46.

Adolf, J.E., Krupatkina, D., Bachvaroff, T., Place, A.R., 2007. Karlotoxin mediates grazing by Oxyrrhis marina on strains of Karlodinium veneficum. Harmful Algae 6, 400-412. https://doi.org/10.1016/j.hal.2006.12.003

Ajani, P., Brett, S., Krogh, M., Scanes, P., Webster, G., Armand, L., 2013. The risk of harmful algal blooms (HABs) in the oyster-growing estuaries of New South Wales, Australia. Environ. Monit. Assess. 185, 5295-5316. https://doi.org/10.1007/s10661-0122946-9 
800

801

802

803

804

805

806

807

808

809

810

811

812

813

814

815

816

817

818

819

820

821

822

823

824

825

826

827

828

829

830

831

832

833

834

835

836

837

838

839

840

Ajani, P., Harwood, D., Murray, S., 2017. Recent Trends in Marine Phycotoxins from Australian Coastal Waters. Mar. Drugs 15, 33. https://doi.org/10.3390/md15020033

Ajani, P.A., Hallegraeff, G.M., Allen, D., Coughlan, A., Richardson, A.J., Armand, L.K., Ingleton, T., Murray, S.A., 2016. Oceanography and Marine Biology, Oceanography and Marine Biology: An Annual Review. CRC Press. https://doi.org/10.1201/9781315368597

Allam, B., Raftos, D., 2015. Immune responses to infectious diseases in bivalves. J. Invertebr. Pathol. 131, 121-136. https://doi.org/10.1016/j.jip.2015.05.005

Amaro, H.M., Guedes, A.C., Malcata, F.X., 2011. Antimicrobial activities of microalgae: an invited review, in: Méndez-Vilas, A. (Ed.), Science against Microbial Pathogens: Communicating Current Research and Technological Advances. pp. 1272-1280.

Anderson, D.M., Burkholder, J.M., Cochlan, W.P., Glibert, P.M., Gobler, C.J., Heil, C.A., Kudela, R.M., Parsons, M.L., Rensel, J.E.J., Townsend, D.W., Trainer, V.L., Vargo, G.A., 2008. Harmful algal blooms and eutrophication: Examining linkages from selected coastal regions of the United States. Harmful Algae 8, 39-53. https://doi.org/10.1016/j.hal.2008.08.017

Andrews, J., 1980. A Review of Introductions of Exotic Oysters and Biological Planning for New Importations. Mar. Fish. Rev. 1-11.

Aquino, E.P., Borges, G.C.P., Honorato-da-Silva, M., Passavante, J.Z.O., Silva-Cunha, M.G.G.S., 2015. Phytoplankton in a tropical estuary, Northeast Brazil: composition and life forms. Check List 11, 1633. https://doi.org/10.15560/11.3.1633

Arzul, G., Seguel, M., Guzman, L., Erard-Le Denn, E., 1999. Comparison of allelopathic properties in three toxic Alexandrium species. J. Exp. Mar. Bio. Ecol. 232, 285-295.

Arzul, I., Carnegie, R.B., 2015. New perspective on the haplosporidian parasites of molluscs. J. Invertebr. Pathol. 131, 32-42. https://doi.org/10.1016/j.jip.2015.07.014

Arzul, I., Corbeil, S., Morga, B., Renault, T., 2017. Viruses infecting marine molluscs. J. Invertebr. Pathol. 147, 118-135. https://doi.org/10.1016/j.jip.2017.01.009

Astuya, A., Carrera, C., Ulloa, V., Aballay, A., Núñez-Acuña, G., Hégaret, H., GallardoEscárate, C., 2015. Saxitoxin modulates immunological parameters and gene transcription in Mytilus chilensis hemocytes. Int. J. Mol. Sci. 16, 15235-15250. https://doi.org/10.3390/ijms160715235

Barbosa Solomieu, V., Renault, T., Travers, M., 2015. Mass mortality in bivalves and the intricate case of the Pacific oyster, Crassostrea gigas. J. Invertebr. Pathol. 131, 2-10. https://doi.org/10.1016/j.jip.2015.07.011

Basti, L., Endo, M., Segawa, S., 2011. Physiological, pathological, and defense alterations in Manila clams (short-neck clams), Ruditapes philippinarum, induced by Heterocapsa circularisquama. J. Shellfish Res. 30, 829-844.

Basti, L., Nagai, K., Tanaka, Y., Segawa, S., 2013. Sensitivity of gametes, fertilization, and embryo development of the Japanese pearl oyster, Pinctada fucata martensii, to the harmful dinoflagellate, Heterocapsa circularisquama. Mar. Biol. 160, 211-219. https://doi.org/10.1007/s00227-012-2079-2 
Berdalet, E., Fleming, L.E., Gowen, R., Davidson, K., Hess, P., Backer, L.C., Moore, S.K., Hoagland, P., Enevoldsen, H., 2015. Marine harmful algal blooms, human health and wellbeing: Challenges and opportunities in the 21st century. J. Mar. Biol. Assoc. United Kingdom. 61-91. https://doi.org/10.1017/S0025315415001733

Berthe, F.C.J., Le Roux, F., Adlard, R., Figueiras, A., Villalba, A., Reece, K.S., Ordás, M.C., Casas, S.M., Figueras, A., 2004. Marteiliosis in Molluscs: a review. Aquat. Living Resour. 17, 433-144. https://doi.org/10.1051/alr

Bianchi, V.A., Langeloh, H., Tillmann, U., Krock, B., Müller, A., Bickmeyer, U., Abele, D., 2019. Separate and combined effects of neurotoxic and lytic compounds of Alexandrium strains on Mytilus edulis feeding activity and hemocyte function. Fish Shellfish Immunol. 84, 414-422. https://doi.org/10.1016/j.fsi.2018.10.024

Binzer, S.B., Svenssen, D.K., Daugbjerg, N., Alves-de-Souza, C., Pinto, E., Hansen, P.J., Larsen, T.O., Varga, E., 2019. A-, B- and C-type prymnesins are clade specific compounds and chemotaxonomic markers in Prymnesium parvum. Harmful Algae 81, 10-17. https://doi.org/10.1016/j.hal.2018.11.010

Borcier, E., Morvezen, R., Boudry, P., Miner, P., Charrier, G., Laroche, J., Hegaret, H., 2017. Effects of bioactive extracellular compounds and paralytic shellfish toxins produced by Alexandrium minutum on growth and behaviour of juvenile great scallops Pecten maximus. Aquat. Toxicol. 184, 142-154. https://doi.org/10.1016/j.aquatox.2017.01.009

Boullot, F., Castrec, J., Bidault, A., Dantas, N., Payton, L., Perrigault, M., Tran, D., Amzil, Z., Boudry, P., Soudant, P., Hégaret, H., Fabioux, C., 2017. Molecular Characterization of Voltage-Gated Sodium Channels and Their Relations with Paralytic Shellfish Toxin Bioaccumulation in the Pacific Oyster Crassostrea gigas. Mar. Drugs 15, 21. https://doi.org/10.3390/md15010021

Branco, S., Almeida, L.L., Alves $\square$ de $\square$ Souza, C., Oliveira, M.M.M., Proença, L.A.O., Menezes, M., 2019. Morphological and genetic characterization of bloom $\square$ forming Raphidophyceae from Brazilian coast. Phycol. Res. pre.12377. https://doi.org/10.1111/pre.12377

Bricelj, V., Ford, S., Lambert, C., Barbou, A., Paillard, C., 2011. Effects of toxic Alexandrium tamarense on behavior, hemocyte responses and development of brown ring disease in Manila clams. Mar. Ecol. Prog. Ser. 430, 35-48. https://doi.org/10.3354/meps09111

Bricelj, V.M., Connell, L., Konoki, K., MacQuarrie, S.P., Scheuer, T., Catterall, W.A., Trainer, V.L., 2005. Sodium channel mutation leading to saxitoxin resistance in clams increases risk of PSP. Nature 434, 763-767.

Bricelj, V.M., MacQuarrie, S.P., Doane, J.A.E., Connell, L.B., 2010. Evidence of selection for resistance to paralytic shellfish toxins during the early life history of soft-shell clam (Mya arenaria) populations. Limnol. Oceanogr. 55, 2463-3590.

Burkholder, J.M., Glibert, P.M., Skelton, H.M., 2008. Mixotrophy, a major mode of nutrition for harmful algal species in eutrophic waters. Harmful Algae 8, 77-93. https://doi.org/10.1016/j.hal.2008.08.010

Burreson, E.M., Ragone-Calvo, L.M., 1996. Epizootiology of Perkinsus marinus disease of oysters in Chesapeake Bay, with emphasis on data since 1985. J. Shellfish Res. 15, 17- 
884

885

886

887

888

889

890

891

892

893

894

895

896

897

898

899

900

901

902

903

904

905

906

907

908

909

910

911

912

913

914

915

916

917

918

919

920

921

922

923

924

Cáceres-Martínez, J., Madero-López, L.H., Padilla-Lardizábal, G., Vásquez-Yeomans, R., 2016. Epizootiology of Perkinsus marinus, parasite of the pleasure oyster Crassostrea corteziensis, in the Pacific coast of Mexico. J. Invertebr. Pathol. 139, 12-18. https://doi.org/10.1016/j.jip.2016.07.003

Cao, R., Wang, D., Wei, Q., Wang, Q., Yang, D., Liu, H., Dong, Z., Zhang, X., Zhang, Q., Zhao, J., 2018. Integrative Biomarker Assessment of the Influence of Saxitoxin on Marine Bivalves: A Comparative Study of the Two Bivalve Species Oysters, Crassostrea gigas, and Scallops, Chlamys farreri. Front. Physiol. 9, 1-14. https://doi.org/10.3389/fphys.2018.01173

Carella, F., Feist, S.W., Bignell, J.P., De Vico, G., 2015. Comparative pathology in bivalves: Aetiological agents and disease processes. J. Invertebr. Pathol. 131, 107-120. https://doi.org/10.1016/j.jip.2015.07.012

Carrasco, N., Green, T., Itoh, N., 2015. Marteilia spp. parasites in bivalves: A revision of recent studies. J. Invertebr. Pathol. 131, 43-57. https://doi.org/10.1016/j.jip.2015.07.016

Caruana, A.M.N., Malin, G., 2014. The variability in DMSP content and DMSP lyase activity in marine dinoflagellates. Prog. Oceanogr. 120, 410-424. https://doi.org/10.1016/j.pocean.2013.10.014

Castrec, J., Hégaret, H., Alunno-Bruscia, M., Picard, M., Soudant, P., Petton, B., Boulais, M., Suquet, M., Quéau, I., Ratiskol, D., Foulon, V., Le Goïc, N., Fabioux, C., 2019. The dinoflagellate Alexandrium minutum affects development of the oyster Crassostrea gigas, through parental or direct exposure. Environ. Pollut. 246, 827-836. https://doi.org/10.1016/j.envpol.2018.11.084

Castrec, J., Hégaret, H., Huber, M., Le Grand, J., Huvet, A., Tallec, K., Boulais, M., Soudant, P., Fabioux, C., 2020. The toxic dinoflagellate Alexandrium minutum impaired oyster free living stages, embryos and larvae. Harmful Algae (in press).

Castrec, J., Soudant, P., Payton, L., Tran, D., Miner, P., Lambert, C., Le Goïc, N., Huvet, A., Quillien, V., Boullot, F., Amzil, Z., Hégaret, H., Fabioux, C., 2018. Bioactive extracellular compounds produced by the dinoflagellate Alexandrium minutum are highly detrimental for oysters. Aquat. Toxicol. 199, 188-198. https://doi.org/10.1016/j.aquatox.2018.03.034

Catterall, 2000. From Ionic Currents to Molecular Review Mechanisms: The Structure and Function of Voltage-Gated Sodium Channels. Neuron 26, 13-25.

Cheng, T.C., 1996. Haemocytes: Forms and functions, in: Kennedy, V., Newell, R., Eble, A. (Eds.), The Eastern Oyster Crassostrea virginica. College Park: Maryland Sea Grant, pp. 299-333.

Choi, K.S., Park, K.I., 2010. Review on the Protozoan parasite Perkinsus olseni (Lester and Davis 1981) infection in asian waters, in: Ishimatsu, A., Lier, H.-J. (Eds.), Coastal Environmental and Ecosystem Issues of the East China Sea. TERRABUP; Nagasaki university, pp. 269-281.

Comps, M., 1988. Epizootic diseases of oysters associated with viral infections. Am. Fish. Soc. Spec. Publ. 18, 23-37. 
Contreras, A.M., Marsden, I.D., Munro, M.H.G., 2011. Effects of short-term exposure to paralytic shellfish toxins on clearance rates and toxin uptake in five species of New Zealand bivalve. Mar. Freshw. Res. 63, 166-174. https://doi.org/http://dx.doi.org/10.1071/MF11173

Cuellar-Martinez, T., Ruiz-Fernández, A.C., Alonso-Hernández, C., Amaya-Monterrosa, O., Quintanilla, R., Carrillo-Ovalle, H.L., Arbeláez M, N., Díaz-Asencio, L., Méndez, S.M., Vargas, M., Chow-Wong, N.F., Valerio-Gonzalez, L.R., Enevoldsen, H., Dechraoui Bottein, M.-Y., 2018. Addressing the Problem of Harmful Algal Blooms in Latin America and the Caribbean- A Regional Network for Early Warning and Response. Front. Mar. Sci. 5, 1-7. https://doi.org/10.3389/fmars.2018.00409

da Silva, P.M., Scardua, M.P., Vianna, R.T., Mendonça, R.C., Vieira, C.B., Dungan, C.F., Scott, G.P., Reece, K.S., 2014. Two Perkinsus spp. infect Crassostrea gasar oysters from cultured and wild populations of the Rio São Francisco estuary, Sergipe, northeastern Brazil. J. Invertebr. Pathol. 119, 62-71. https://doi.org/10.1016/j.jip.2014.04.005

da Silva, P.P.M., Hégaret, H., Lambert, C., Wikfors, G.H., Le Goïc, N., Shumway, S.E., Soudant, P., 2008. Immunological responses of the Manila clam (Ruditapes philippinarum) with varying parasite (Perkinsus olseni) burden, during a long-term exposure to the harmful alga, Karenia selliformis, and possible interactions. Toxicon 51, 563-573. https://doi.org/10.1016/j.toxicon.2007.11.006

Dang, C., de Montaudouin, X., Caill-Milly, N., Trumbic, Z., 2010. Spatio-temporal patterns of perkinsosis in the Manila clam Ruditapes philippinarum from Arcachon Bay (SW France). Dis. Aquat. Organ. 91, 151-159.

De Carli, G., 2014. Distribuição e abundância de dinoflagelados epi-bentônicos na costa Nordeste do Brasil. Dissertação de Mestrado, Universidade Federal do Estado do Rio de Janeiro.

de Kantzow, M., Hick, P., Becker, J., Whittington, R., 2016. Effect of water temperature on mortality of Pacific oysters Crassostrea gigas associated with microvariant ostreid herpesvirus 1 (OsHV-1 $\mu$ Var). Aquac. Environ. Interact. 8, 419-428. https://doi.org/10.3354/aei00186

de Lorgeril, J., Lucasson, A., Petton, B., Toulza, E., Montagnani, C., Clerissi, C., VidalDupiol, J., Chaparro, C., Galinier, R., Escoubas, J.-M., Haffner, P., Dégremont, L., Charrière, G.M., Lafont, M., Delort, A., Vergnes, A., Chiarello, M., Faury, N., Rubio, T., Leroy, M.A., Pérignon, A., Régler, D., Morga, B., Alunno-Bruscia, M., Boudry, P., Le Roux, F., Destoumieux-Garzón, D., Gueguen, Y., Mitta, G., 2018. Immune-suppression by OsHV-1 viral infection causes fatal bacteraemia in Pacific oysters. Nat. Commun. 9, 4215. https://doi.org/10.1038/s41467-018-06659-3

De Rijcke, M., Van Acker, E., Nevejan, N., De Schamphelaere, K.A.C., Janssen, C.R., 2016. Toxic dinoflagellates and Vibrio spp. act independently in bivalve larvae. Fish Shellfish Immunol. 57, 236-242. https://doi.org/10.1016/j.fsi.2016.08.027

De Vico, G., Carella, F., 2012. Morphological features of the inflammatory response in molluscs. Res. Vet. Sci. 93, 1109-1115. https://doi.org/10.1016/j.rvsc.2012.03.014

Destoumieux-Garzón, D., Rosa, R.D., Schmitt, P., Barreto, C., Vidal-Dupiol, J., Mitta, G., 
Gueguen, Y., Bachère, E., 2016. Antimicrobial peptides in marine invertebrate health and disease: Table 1. Philos. Trans. R. Soc. B Biol. Sci. 371, 20150300. https://doi.org/10.1098/rstb.2015.0300

Dizer, H., Fischer, B., Harabawy, A.S.., Hennion, M.-C., Hansen, P.-D., 2001. Toxicity of domoic acid in the marine mussel Mytilus edulis. Aquat. Toxicol. 55, 149-156. https://doi.org/10.1016/S0166-445X(01)00178-3

Dorantes-Aranda, J.J., Seger, A., Mardones, J.I., Nichols, P.D., Hallegraeff, G.M., 2015. Progress in Understanding Algal Bloom-Mediated Fish Kills: The Role of Superoxide Radicals, Phycotoxins and Fatty Acids. PLoS One 10, e0133549. https://doi.org/10.1371/journal.pone.0133549

Doucette, G.J., 1995. Interactions between bacteria and harmful algae: a review. Nat. Toxins $3,65-74$.

Dove, M., Nell, J.A., Mcorrie, S., O'connor, W.A., 2013. Assessment of Qx and Winter Mortality Disease Resistance of Mass Selected Sydney Rock Oysters, Saccostrea glomerata (Gould, 1850), in the Hawkesbury River and Merimbula Lake, NSW Australia. J. Shellfish Res. 32, 681-687. https://doi.org/10.2983/035.032.0309

Dubert, J., Barja, J.L., Romalde, J.L., 2017. New Insights into Pathogenic Vibrios Affecting Bivalves in Hatcheries: Present and Future Prospects. Front. Microbiol. 8, 1-16. https://doi.org/10.3389/fmicb.2017.00762

Dyachuk, V.A., 2016. Hematopoiesis in Bivalvia larvae: Cellular origin, differentiation of hemocytes, and neoplasia. Dev. Comp. Immunol. 65, 253-257. https://doi.org/10.1016/j.dci.2016.07.019

Enríquez-Espinoza, T., Grijalva-Chon, J., Castro-Longoria, R., Ramos-Paredes, J., 2010. Perkinsus marinus in Crassostrea gigas in the Gulf of California. Dis. Aquat. Organ. 89, 269-273. https://doi.org/10.3354/dao02199

Estrada, N., Ascencio, F., Shoshani, L., Contreras, R.G., 2014. Apoptosis of hemocytes from lions-paw scallop Nodipecten subnodosus induced with paralyzing shellfish poison from Gymnodinium catenatum. Immunobiology 219, 964-974. https://doi.org/10.1016/j.imbio.2014.07.006

Estrada, N., Rodríguez-Jaramillo, C., Contreras, G., Ascencio, F., 2010. Effects of induced paralysis on hemocytes and tissues of the giant lions-paw scallop by paralyzing shellfish poison. Mar. Biol. 157, 1401-1415. https://doi.org/10.1007/s00227-010-1418-4

Evans, O., Hick, P., Dhand, N., Whittington, R., 2015. Transmission of Ostreid herpesvirus-1 in Crassostrea gigas by cohabitation: effects of food and number of infected donor oysters. Aquac. Environ. Interact. 7, 281-295. https://doi.org/10.3354/aei00160

Evans, O., Paul-Pont, I., Hick, P., Whittington, R.J., 2014. A simple centrifugation method for improving the detection of Ostreid herpesvirus-1 (OsHV-1) in natural seawater samples with an assessment of the potential for particulate attachment. J. Virol. Methods 210, 5966. https://doi.org/10.1016/j.jviromet.2014.09.023

Farias, N.D., de Oliveira, N.F.P., da Silva, P.M., 2017. Perkinsus infection is associated with alterations in the level of global DNA methylation of gills and gastrointestinal tract of the oyster Crassostrea gasar. J. Invertebr. Pathol. 149, 76-81. 
Farley, C., Wolf, P., Elston, R., 1988. A long-term study of 'microcell' disease in oysters with a description of a new genus, Mikrocytos (g. n.), and two new species, Mikrocytos mackini (sp. n.) and Mikrocytos roughleyi (sp. n.). Fish. Bull. 86, 581-593.

1014

1015

1016

1017

1018

1019

1020

1021

1022

1023

1024

1025

1026

1027

1028

1029

1030

1031

1032

1033

1034

1035

1036

1037

1038

1039

1040

1041

1042

1043

1044

1045

1046

1047

1048

1049

1050

Farrell, H., Seebacher, F., O'Connor, W., Zammit, A., Harwood, D.T., Murray, S., 2015. Warm temperature acclimation impacts metabolism of paralytic shellfish toxins from Alexandrium minutum in commercial oysters. Glob. Chang. Biol. 21, 3402-3413. https://doi.org/10.1111/gcb.12952

Flores, H.S., Wikfors, G.H., Dam, H.G., 2012. Reactive oxygen species are linked to the toxicity of the dinoflagellate Alexandrium spp. to protists. Aquat. Microb. Ecol. 66, 199209.

Ford, S.E., Bricelj, V.M., Lambert, C., Paillard, C., 2008. Deleterious effects of a nonPST bioactive compound(s) from Alexandrium tamarense on bivalve hemocytes. Mar. Biol. 154, 241-253. https://doi.org/10.1007/s00227-008-0917-z

Ford, S.E., Smolowitz, R., 2007. Infection dynamics of an oyster parasite in its newly expanded range. Mar. Biol. 151, 119-133. https://doi.org/10.1007/s00227-006-0454-6

Fournier, M., Cyr, D., Blakley, B., Boermans, H., Brousseau, P., 2000. Phagocytosis as a biomarker of immunotoxicity in wildlife species exposed to environmental xenobiotics. Am. Zool. 40, 412-420.

Fraga, S., Sampedro, N., Larsen, J., Moestrup, Ø, Calado, A., 2015. Arguments against the proposal 2302 by John \& al. to reject the name Gonyaulax catenella (Alexandrium catenella).Taxon 64(3), 634-635. http://dx.doi.org/10.12705/643.15

Franchini, A., Milandri, A., Poletti, R., Ottaviani, E., 2003. Immunolocalization of yessotoxins in the mussel Mytilus galloprovincialis. Toxicon 41, 967-970. https://doi.org/10.1016/S0041-0101(03)00039-4

Galimany, E., Place, A.R., Jutson, M., Pipe, R.K., 2008a. The effects of feeding Karlodinium veneficum (PLY \# 103; Gymnodinium veneficum Ballantine) to the blue mussel Mytilus edulis 7, 91-98. https://doi.org/10.1016/j.hal.2007.05.004

Galimany, E., Sunila, I., Hégaret, H., Ramón, M., Wikfors, G.H., 2008b. Experimental exposure of the blue mussel (Mytilus edulis, L.) to the toxic dinoflagellate Alexandrium fundyense: Histopathology, immune responses, and recovery. Harmful Algae 7, 702711. https://doi.org/10.1016/j.hal.2008.02.006

Galimany, E., Sunila, I., Hégaret, H., Ramón, M., Wikfors, G.H., 2008c. Pathology and immune response of the blue mussel (Mytilus edulis L.) after an exposure to the harmful dinoflagellate Prorocentrum minimum. Harmful Algae 7, 630-638. https://doi.org/10.1016/j.hal.2008.01.001

Gerssen, A., Pol-Hofstad, I.E., Poelman, M., Mulder, P.P.J., Van den Top, H.J., De Boer, J., 2010. Marine Toxins: Chemistry, Toxicity, Occurrence and Detection, with Special Reference to the Dutch Situation. Toxins (Basel). 2, 878-904. https://doi.org/10.3390/toxins2040878

Gittenberger, A., Voorbergen-Laarman, M.A., Engelsma, M.Y., 2016. Ostreid herpesvirus 
OsHV-1 $\mu$ Var in Pacific oysters Crassostrea gigas (Thunberg 1793) of the Wadden Sea, a UNESCO world heritage site. J. Fish Dis. 39, 105-109. https://doi.org/10.1111/jfd.12332

1054

1055

1056

1057

1058

1059

1060

1061

1062

1063

1064

1065

1066

1067

1068

1069

1070

1071

1072

1073

1074

1075

1076

1077

1078

1079

1080

1081

1082

1083

1084

1085

1086

1087

1088

1089

1090

1091

1092

Glibert, P.M., 2017. Eutrophication, harmful algae and biodiversity - Challenging paradigms in a world of complex nutrient changes. Mar. Pollut. Bull. 124, 591-606. https://doi.org/10.1016/j.marpolbul.2017.04.027

Gobler, C.J., Doherty, O.M., Hattenrath-Lehmann, T.K., Griffith, A.W., Kang, Y., Litaker, R.W., 2017. Ocean warming since 1982 has expanded the niche of toxic algal blooms in the North Atlantic and North Pacific oceans. Proc. Natl. Acad. Sci. 114, 4975-4980. https://doi.org/10.1073/pnas.1619575114

Gorbi, S., Avio, G.C., Benedetti, M., Totti, C., Accoroni, S., Pichierri, S., Bacchiocchi, S., Orletti, R., Graziosi, T., Regoli, F., 2013. Effects of harmful dinoflagellate Ostreopsis $c f$. ovata exposure on immunological, histological and oxidative responses of mussels Mytilus galloprovincialis. Fish Shellfish Immunol. 35, 941-950. https://doi.org/10.1016/j.fsi.2013.07.003

Goulletquer, P., Héral, M., Rothschild, B.J., 1994. Causes of decline of oyster production (Crassostrea virginica) in the Maryland portion of the Chesapeake Bay: A literature study. Haliotis 23, 87-112.

Green, T.J., Raftos, D., O’Connor, W., Adlard, R.D., Barnes, A.C., 2011. Disease Prevention Strategies for QX Disease (Marteilia sydneyi) of Sydney Rock Oysters (Saccostrea glomerata). J. Shellfish Res. 30, 47-53. https://doi.org/10.2983/035.030.0108

Grizel, H., Comps, M., Bonami, J.R., Cousserans, F., Duthoit, J.L., Pennec, M., 1974. Epizooty of the common oyster Ostrea edulis, Part 1. Study of the agent of digestive gland disease in Ostrea edulis Linne. Sci. Pêche 240-241, 1-30.

Grizel, H., Héral, M., 1991. Introduction into France of the Japanese oyster (Crassostrea gigas). J. du Cons. Int. pour l' Explot. la Mer 399-403.

Guo, X., He, Y., Zhang, L., Lelong, C., Jouaux, A., 2015. Immune and stress responses in oysters with insights on adaptation. Fish Shellfish Immunol. 46, 107-119. https://doi.org/10.1016/j.fsi.2015.05.018

Haberkorn, H., Lambert, C., Le Goïc, N., Guéguen, M., Moal, J., Palacios, E., Lassus, P., Soudant, P., 2010a. Effects of Alexandrium minutum exposure upon physiological and hematological variables of diploid and triploid oysters, Crassostrea gigas. Aquat. Toxicol. 97, 96-108. https://doi.org/10.1016/j.aquatox.2009.12.006

Haberkorn, H., Lambert, C., Le Goïc, N., Moal, J., Suquet, M., Guéguen, M., Sunila, I., Soudant, P., 2010b. Effects of Alexandrium minutum exposure on nutrition-related processes and reproductive output in oysters Crassostrea gigas. Harmful Algae 9, 427439. https://doi.org/10.1016/j.hal.2010.01.003

Haberkorn, H., Lambert, C., Le Goïc, N., Quéré, C., Bruneau, A., Riso, R., Auffret, M., Soudant, P., 2014. Cellular and biochemical responses of the oyster Crassostrea gigas to controlled exposures to metals and Alexandrium minutum. Aquat. Toxicol. 147, 158167. https://doi.org/10.1016/j.aquatox.2013.12.012

Haberkorn, H., Tran, D., Massabuau, J.-C., Ciret, P., Soudant, P., 2011. Relationship between 
1093

1094

1095

1096

1097

1098

1099

1100

1101

1102

1103

1104

1105

1106

1107

1108

1109

1110

1111

1112

1113

1114

1115

1116

1117

1118

1119

1120

1121

1122

1123

1124

1125

1126

1127

1128

1129

1130

1131

1132

1133

1134

valve activity, microalgae concentration in the water and toxin accumulation in the digestive gland of the Pacific oyster Crassostrea gigas exposed to Alexandrium minutum. Mar. Pollut. Bull. 62, 1191-1197.

HABSOS, 2019. Karenia brevis [WWW Document]. Harmful Algal Bloom Obs. Syst. URL https://service.ncddc.noaa.gov/website/AGSViewers/HABSOS/maps.htm (accessed 7.18.19).

Hallegraeff, G., Dorantes-Aranda, J.J., Mardones, J., Seger, A., 2017. Review of progress in our understanding of fish-killing microalgae: implications for management and mitigation. In: Proença, L. A. O. and Hallegraeff , G.M. (eds). Marine and Fresh-Water Harmful Algae. Proceedings of the $17^{\text {th }}$ International Conference on Harmful Algae. International Society for the Study of Harmful Algae and Intergovernmental Oceanographic Commission of UNESCO 2017.

Hallegraeff, G.M., 1993. A review of harmful algal blooms and their apparent global increase. Phycologia 32, 79-99. https://doi.org/10.2216/i0031-8884-32-2-79.1

Hasui, M., Matsuda, M., Okutani, K., Shigeta, S., 1995. In vitro antiviral activities of sulfated polysaccharides from a marine microalga (Cochlodinium polykrikoides) against human immunodeficiency virus and other enveloped viruses. Int. J. Biol. Macromol. 17, 293 297. https://doi.org/10.1016/0141-8130(95)98157-T

Hégaret, H., Brokordt, K.B., Gaymer, C.F., Lohrmann, K.B., García, C., Varela, D., 2012. Effects of the toxic dinoflagellate Alexandrium catenella on histopathogical and escape responses of the Northern scallop Argopecten purpuratus. Harmful Algae 18, 74-83. https://doi.org/10.1016/j.hal.2012.04.006

Hégaret, H., da Silva, P., Wikfors, G., Lambert, C., Debettignies, T., Shumway, S., Soudant, P., 2007a. Hemocyte responses of Manila clams, Ruditapes philippinarum, with varying parasite, Perkinsus olseni, severity to toxic-algal exposures. Aquat. Toxicol. 84, 469479. https://doi.org/10.1016/j.aquatox.2007.07.007

Hégaret, H., da Silva, P.M., Sunila, I., Shumway, S.E., Dixon, M.S., Alix, J., Wikfors, G.H., Soudant, P., 2009. Perkinsosis in the Manila clam Ruditapes philippinarum affects responses to the harmful-alga, Prorocentrum minimum. J. Exp. Mar. Bio. Ecol. 371, 112-120. https://doi.org/10.1016/j.jembe.2009.01.016

Hégaret, H., da Silva, P.M., Wikfors, G.H., Haberkorn, H., Shumway, S.E., Soudant, P., 2011. In vitro interactions between several species of harmful algae and haemocytes of bivalve molluscs. Cell Biol. Toxicol. 27, 249-266.

Hégaret, H., Smolowitz, R.M., Sunila, I., Shumway, S.E., Alix, J., Dixon, M., Wikfors, G.H., 2010. Combined effects of a parasite, QPX, and the harmful-alga, Prorocentrum minimum on northern quahogs, Mercenaria mercenaria. Mar. Environ. Res. 69, 337344. https://doi.org/10.1016/j.marenvres.2009.12.008

Hégaret, H., Wikfors, G., Soudant, P., Lambert, C., Shumway, S.E., Bérard, J.B., Lassus, P., 2007b. Toxic dinoflagellates (Alexandrium fundyense and A. catenella) have minimal apparent effects on oyster hemocytes. Mar. Biol. 152, 441-447. https://doi.org/10.1007/s00227-007-0703-3

Hégaret, H., Wikfors, G.H., 2005a. Effects of natural and field-simulated blooms of the 
1135

1136

1137

1138

1139

1140

1141

1142

1143

1144

1145

1146

1147

1148

1149

1150

1151

1152

1153

1154

1155

1156

1157

1158

1159

1160

1161

1162

1163

1164

1165

1166

1167

1168

1169

1170

1171

1172

1173

1174

1175

1176

dinoflagellate Prorocentrum minimum upon hemocytes of eastern oysters, Crassostrea virginica, from two different populations. Harmful Algae 4, 201-209. https://doi.org/10.1016/j.hal.2003.12.005

Hégaret, H., Wikfors, G.H., 2005b. Time-dependent changes in hemocytes of eastern oysters, Crassostrea virginica, and northern bay scallops, Argopecten irradians irradians, exposed to a cultured strain of Prorocentrum minimum. Harmful Algae 4, 187-199. https://doi.org/10.1016/j.hal.2003.12.004

Hégaret, H., Wikfors, G.H., Shumway, S.E., 2007c. Diverse Feeding Responses of Five Species of Bivalve Mollusc When Exposed To Three Species of Harmful Algae. J. Shellfish Res. 26, 549-559. https://doi.org/10.2983/07308000(2007)26[549:dfrofs]2.0.co;2

Hermabessiere, L., Fabioux, C., Lassudrie, M., Boullot, F., Long, M., Lambert, C., Le Goïc, N., Gouriou, J., Le Gac, M., Chapelle, A., Soudant, P., Hégaret, H., 2016. Influence of gametogenesis pattern and sex on paralytic shellfish toxin levels in triploid Pacific oyster Crassostrea gigas exposed to a natural bloom of Alexandrium minutum. Aquaculture. https://doi.org/10.1016/j.aquaculture.2016.01.001

Hill, K., Stokes, N., Webb, S., Hine, P., Kroeck, M., Moore, J., Morley, M., Reece, K., Burreson, E., Carnegie, R., 2014. Phylogenetics of Bonamia parasites based on small subunit and internal transcribed spacer region ribosomal DNA sequence data. Dis. Aquat. Organ. 110, 33-54. https://doi.org/10.3354/dao02738

Hine, P., Cochennec-Laureau, N., Berthe, F., 2001. Bonamia exitiosus n.sp. (Haplosporidia) infecting flat oysters Ostrea chilensis in New Zealand. Dis. Aquat. Organ. 47, 63-72. https://doi.org/10.3354/dao047063

Hughes, F.M., Foster, B., Grewal, S., Sokolova, I.M., 2010. Apoptosis as a host defense mechanism in Crassostrea virginica and its modulation by Perkinsus marinus. Fish Shellfish Immunol. 29, 247-257. https://doi.org/10.1016/j.fsi.2010.03.003

Jales, M.C., Antônio, F., Koening, M.L., 2013. The reef ecosystem of Serrambi (Pernambuco State, Brazil): phytoplankton composition. Arq. Ciências do Mar 46, 27-39.

Jauffrais, T., Contreras, A., Herrenknecht, C., Truquet, P., Séchet, V., Tillmann, U., Hess, P., 2012. Effect of Azadinium spinosum on the feeding behaviour and azaspiracid accumulation of Mytilus edulis. Aquat. Toxicol. 124-125, 179-187. https://doi.org/10.1016/j.aquatox.2012.08.016

Jenkins, C., Hick, P., Gabor, M., Spiers, Z., Fell, S., Gu, X., Read, A., Go, J., Dove, M., O'Connor, W., Kirkland, P., Frances, J., 2013. Identification and characterisation of an ostreid herpesvirus-1 microvariant (OsHV-1 $\mu$-var) in Crassostrea gigas (Pacific oysters) in Australia. Dis. Aquat. Organ. 105, 109-126. https://doi.org/10.3354/dao02623

John U., Litaker R.W., Montresor M., Murray S., Brosnahan M.L., Anderson, D.M. 2014. Formal revision of the Alexandrium tamarense species complex (Dinophyceae) taxonomy: the introduction of five species with emphasis on molecular-based (rDNA) classification. Protist 165, 779-804. https://doi.org/10.1016/j.protis.2014.10.001

Kellam, S.J., Walker, J.M., 1989. Antibacterial activity from marine microalgae in laboratory 
culture. Br. Phycol. J. 24, 191-194. https://doi.org/10.1080/00071618900650181

1178

1179

1180

1181

1182

1183

1184

1185

1186

1187

1188

1189

1190

1191

1192

1193

1194

1195

1196

1197

1198

1199

1200

1201

1202

1203

1204

1205

1206

1207

1208

1209

1210

1211

1212

1213

1214

1215

1216

1217

1218

Kiene, R.P., Linn, L.J., Bruton, J.A., 2000. New and important roles for DMSP in marine microbial communities. J. Sea Res. 43, 209-224. https://doi.org/10.1016/S13851101(00)00023-X

Kleeman, S.., Adlard, R.., Lester, R.J.., 2002. Detection of the initial infective stages of the protozoan parasite Marteilia sydneyi in Saccostrea glomerata and their development through to sporogenesis. Int. J. Parasitol. 32, 767-784. https://doi.org/10.1016/S00207519(02)00025-5

Kokou, F., Makridis, P., Kentouri, M., Divanach, P., 2012. Antibacterial activity in microalgae cultures. Aquac. Res. 43, 1520-1527. https://doi.org/10.1111/j.13652109.2011.02955.x

Lafont, M., Goncalves, P., Guo, X., Montagnani, C., Raftos, D., Green, T., 2019. Transgenerational plasticity and antiviral immunity in the Pacific oyster (Crassostrea gigas) against Ostreid herpesvirus 1 (OsHV-1). Dev. Comp. Immunol. 91, 17-25. https://doi.org/10.1016/j.dci.2018.09.022

Lafont, M., Petton, B., Vergnes, A., Pauletto, M., Segarra, A., Gourbal, B., Montagnani, C., 2017. Long-lasting antiviral innate immune priming in the Lophotrochozoan Pacific oyster, Crassostrea gigas. Sci. Rep. 7, 13143. https://doi.org/10.1038/s41598-01713564-0

Landsberg, J.H.J.H., 2002. The Effects of Harmful Algal Blooms on Aquatic Organisms. Rev. Fish. Sci. 10, 113-390. https://doi.org/10.1080/20026491051695

Lane, H., Webb, S., Duncan, J., 2016. Bonamia ostreae in the New Zealand oyster Ostrea chilensis: a new host and geographic record for this haplosporidian parasite. Dis. Aquat. Organ. 118, 55-63. https://doi.org/10.3354/dao02960

Lassudrie, M., Soudant, P., Nicolas, J.-L., Fabioux, C., Lambert, C., Miner, P., Le Grand, J., Petton, B., Hégaret, H., 2015a. Interaction between toxic dinoflagellate Alexandrium catenella exposure and disease associated with herpesvirus OsHV-1 $\mu$ Var in Pacific oyster spat Crassostrea gigas. Harmful Algae 45, 53-61. https://doi.org/10.1016/j.hal.2015.04.007

Lassudrie, M., Soudant, P., Nicolas, J.-L., Miner, P., Le Grand, J., Lambert, C., Le Goïc, N., Hégaret, H., Fabioux, C., 2016. Exposure to the toxic dinoflagellate Alexandrium catenella modulates juvenile oyster Crassostrea gigas hemocyte variables subjected to different biotic conditions. Fish Shellfish Immunol. 51, 104-115. https://doi.org/10.1016/j.fsi.2016.02.017

Lassudrie, M., Soudant, P., Richard, G., Henry, N., Medhioub, W., da Silva, P.M., Donval, A., Bunel, M., Le Goïc, N., Lambert, C., de Montaudouin, X., Fabioux, C., Hégaret, H., 2014. Physiological responses of Manila clams Venerupis (=Ruditapes) philippinarum with varying parasite Perkinsus olseni burden to toxic algal Alexandrium ostenfeldii exposure. Aquat. Toxicol. 154, 27-38. https://doi.org/10.1016/j.aquatox.2014.05.002

Lassudrie, M., Wikfors, G.H., Sunila, I., Alix, J.H., Dixon, M.S., Combot, D., Soudant, P., Fabioux, C., Hégaret, H., 2015b. Physiological and pathological changes in the eastern oyster Crassostrea virginica infested with the trematode Bucephalus sp. and exposed to 
the toxic dinoflagellate Alexandrium fundyense. J. Invertebr. Pathol. 126, 51-63. https://doi.org/10.1016/j.jip.2015.01.011

1221

1222

1223

1224

1225

1226

1227

1228

1229

1230

1231

1232

1233

1234

1235

1236

1237

1238

1239

1240

1241

1242

1243

1244

1245

1246

1247

1248

1249

1250

1251

1252

1253

1254

1255

1256

1257

1258

1259

1260

Lassus, P., Amzil, Z., Baron, R., Séchet, V., Barillé, L., Abadie, E., Bardouil, M., Sibat, M., Truquet, P., Bérard, J., Gueguen, M., 2007. Modelling the accumulation of PSP toxins in Thau Lagoon oysters (Crassostrea gigas) from trials using mixed cultures of Alexandrium catenella and Thalassiosira weissflogii. Aquat. Living Resour. 67, 59-67.

Lassus, P., Bardouil, M., Beliaeff, B., Masselin, P., Naviner, M., Truquet, P., 1999. Effect of continuous supply of the toxic dinoflagellate Alexandrium minutum Halim on the feeding behaviour of the Pacific oyster (Crassostrea gigas Thunberg). J. Shellfish Res. 18, $211-$ 216.

Lassus, P., Chomérat, N., Hess, P., Nézan, E., 2016. Toxic and harmful microalgae of the World Ocean. Denmark, International Society for the Study of Harmful Alge / Intergovernmental Oceanographic Comission of UNESCO. IOC Manuals and Guides, 68.

Lau, Y.-T., Gambino, L., Santos, B., Pales Espinosa, E., Allam, B., 2018a. Transepithelial migration of mucosal hemocytes in Crassostrea virginica and potential role in Perkinsus marinus pathogenesis. J. Invertebr. Pathol. 153, 122-129. https://doi.org/10.1016/j.jip.2018.03.004

Lau, Y.-T., Gambino, L., Santos, B., Pales Espinosa, E., Allam, B., 2018b. Regulation of oyster (Crassostrea virginica) hemocyte motility by the intracellular parasite Perkinsus marinus: A possible mechanism for host infection. Fish Shellfish Immunol. 78, 18-25. https://doi.org/10.1016/j.fsi.2018.04.019

Lau, Y.-T., Santos, B., Barbosa, M., Pales Espinosa, E., Allam, B., 2018c. Regulation of apoptosis-related genes during interactions between oyster hemocytes and the alveolate parasite Perkinsus marinus. Fish Shellfish Immunol. 83, 180-189. https://doi.org/10.1016/j.fsi.2018.09.006

Lauritano, C., Andersen, J.H., Hansen, E., Albrigtsen, M., Escalera, L., Esposito, F., Helland, K., Hanssen, K.Ø., Romano, G., Ianora, A., 2016. Bioactivity Screening of Microalgae for Antioxidant, Anti-Inflammatory, Anticancer, Anti-Diabetes, and Antibacterial Activities. Front. Mar. Sci. 3, 1-12. https://doi.org/10.3389/fmars.2016.00068

Le Goïc, N., Hégaret, H., Boulais, M., Béguel, J.-P.P., Lambert, C., Fabioux, C., Soudant, P., 2014. Flow cytometric assessment of morphology, viability, and production of reactive oxygen species of Crassostrea gigas oocytes. Application to Toxic dinoflagellate (Alexandrium minutum) exposure. Cytom. Part A 85, 1049-1056. https://doi.org/10.1002/cyto.a.22577

Le Goïc, N., Hégaret, H., Fabioux, C., Miner, P., Suquet, M., Lambert, C., Soudant, 2013. Impact of the toxic dinoflagellate Alexandrium catenella on Pacific oyster reproductive output: application of flow cytometry assays on spermatozoa. Aquat. Living Ressources 26, 221-228.

Lee, C.-K., Park, T.-G., Park, Y.-T., Lim, W.-A., 2013. Monitoring and trends in harmful algal blooms and red tides in Korean coastal waters, with emphasis on Cochlodinium polykrikoides. Harmful Algae 30, S3-S14. https://doi.org/10.1016/j.hal.2013.10.002 
Lefebvre, K. a, Bill, B.D., Erickson, A., Baugh, K. a, O’Rourke, L., Costa, P.R., Nance, S., Trainer, V.L., 2008. Characterization of intracellular and extracellular saxitoxin levels in both field and cultured Alexandrium spp. samples from Sequim Bay, Washington. Mar. Drugs 6, 103-116. https://doi.org/10.3390/md20080006

Lelong, A., Haberkorn, H., Le Goïc, N., Hégaret, H., Soudant, P., 2011. A new insight into allelopathic effects of Alexandrium minutum on photosynthesis and respiration of the diatom Chaetoceros neogracile revealed by photosynthetic-performance analysis and flow cytometry. Microb. Ecol. 62, 919-930. https://doi.org/10.1007/s00248-011-9889-5

Levican, A., Lasa, A., Irgang, R., Romalde, J.L., Poblete-Morales, M., Avendaño-Herrera, R., 2017. Isolation of Vibrio tapetis from two native fish species (Genypterus chilensis and Paralichthys adspersus) reared in Chile and description of Vibrio tapetis subsp. quintayensis subsp. nov. Int. J. Syst. Evol. Microbiol. 67, 716-723. https://doi.org/10.1099/ijsem.0.001705

Li, Y., Song, X., Wang, W., Wang, L., Yi, Q., Jiang, S., Jia, Z., Du, X., Qiu, L., Song, L., 2017. The hematopoiesis in gill and its role in the immune response of Pacific oyster Crassostrea gigas against secondary challenge with Vibrio splendidus. Dev. Comp. Immunol. 71, 59-69. https://doi.org/10.1016/j.dci.2017.01.024

Litaker, W.; Sampedro, N., Calado, A., 2018. A practical guide to new nomenclature for species within the "Alexandrium tamarense species complex", Harmful algae news 61: $13-15$

Long, M., Tallec, K., Soudant, P., Lambert, C., Le Grand, F., Sarthou, G., Jolley, D., Hégaret, H., 2018a. A rapid quantitative fluorescence-based bioassay to study allelochemical interactions from Alexandrium minutum. Environ. Pollut. 242, 1598-1605. https://doi.org/10.1016/j.envpol.2018.07.119

Long, M., Tallec, K., Soudant, P., Le Grand, F., Donval, A., Lambert, C., Sarthou, G., Jolley, D.F., Hégaret, H., 2018b. Allelochemicals from Alexandrium minutum induce rapid inhibition of metabolism and modify the membranes from Chaetoceros muelleri. Algal Res. 35, 508-518. https://doi.org/10.1016/j.algal.2018.09.023

Ma, H., Krock, B., Tillmann, U., Cembella, A., 2009. Preliminary Characterization of Extracellular Allelochemicals of the Toxic Marine Dinoflagellate Alexandrium tamarense Using a Rhodomonas salina Bioassay. Mar. Drugs 7, 497-522. https://doi.org/10.3390/md7040497

Ma, H., Krock, B., Tillmann, U., Muck, A., Wielsch, N., Svatoš, A., Cembella, A., 2011. Isolation of activity and partial characterization of large non-proteinaceous lytic allelochemicals produced by the marine dinoflagellate Alexandrium tamarense. Harmful Algae 11, 65-72. https://doi.org/10.1016/j.hal.2011.07.004

Machado, R.C.A., Feitosa, F.A.N., Koening, M.L., Flores Montes, M.J., 2018. Spatial and seasonal variation of the phytoplankton community structure in a reef ecosystem in North-eastern Brazil. J. Mar. Biol. Assoc. United Kingdom 98, 557-566. https://doi.org/10.1017/S0025315416001600

Mackin, J.G., Owen, H.M., 1950. Preliminary note on the occurrence of a new protistan parasite, Dermocystidium marinum. J. Perinat. Med. 111, 328-329. https://doi.org/10.1515/jpme.1982.10.5.249 
Mafra, L.L., Fernandes, L.F., Proença, L.A.O., 2006. Harmful algae and toxis in Paranaguá bay, Brazil: bases for monitoring. Brazilian J. Oceanogr. 54, 107-121. https://doi.org/10.1590/S1679-87592006000200002

Mafra, L.L., Ribas, T., Alves, T.P., Proença, L.A.O., Schramm, M.A., Uchida, H., Suzuki, T., 2015. Differential okadaic acid accumulation and detoxification by oysters and mussels during natural and simulated Dinophysis blooms. Fish. Sci. 81, 749-762. https://doi.org/10.1007/s12562-015-0882-7

Marteil, L., 1976. La conchyliculture francaise. 2eme partie. Biologie de l'huître et de la moule. Rev. des Trav. l'Institut des Pêches Marit. 40, 149-346.

Medhioub, W., Lassus, P., Truquet, P., Bardouil, M., Amzil, Z., Sechet, V., Sibat, M., Soudant, P., 2012. Spirolide uptake and detoxification by Crassostrea gigas exposed to the toxic dinoflagellate Alexandrium ostenfeldii. Aquaculture 358-359, 108-115. https://doi.org/10.1016/j.aquaculture.2012.06.023

Medhioub, W., Ramondenc, S., Vanhove, A.S., Vergnes, A., Masseret, E., Savar, V., Amzil, Z., Laabir, M., Rolland, J.L., 2013. Exposure to the neurotoxic dinoflagellate, Alexandrium catenella, induces apoptosis of the hemocytes of the oyster, Crassostrea gigas. Mar. Drugs 11, 4799-4814. https://doi.org/10.3390/md11124799

Mello, D.F., da Silva, P.M., Barracco, M.A., Soudant, P., Hégaret, H., 2013. Effects of the dinoflagellate Alexandrium minutum and its toxin (saxitoxin) on the functional activity and gene expression of Crassostrea gigas hemocytes. Harmful Algae 26, 45-51. https://doi.org/10.1016/j.hal.2013.03.003

Mello, D.F., Danielli, N.M., Curbani, F., Pontinha, V.A., Suhnel, S., Castro, M.A.M., Medeiros, S.C., Wendt, N.C., Trevisan, R., Magalhães, A.R.M., Dafre, A.L., 2018. First evidence of viral and bacterial oyster pathogens in the Brazilian coast. J. Fish Dis. 41, 559-563. https://doi.org/10.1111/jfd.12755

Mello, D.F., de Oliveira, E.S., Vieira, R.C., Simoes, E., Trevisan, R., Dafre, A.L., Barracco, M.A., 2012. Cellular and Transcriptional Responses of Crassostrea gigas Hemocytes Exposed in Vitro to Brevetoxin (PbTx-2). Mar. Drugs 10, 583-597. https://doi.org/10.3390/md10030583

Mello, D.F., Proença, L.A. de O., Barracco, M.A., 2010. Comparative Study of Various Immune Parameters in Three Bivalve Species during a Natural Bloom of Dinophysis acuminata in Santa Catarina Island, Brazil. Toxins (Basel). 2, 1166-1178. https://doi.org/10.3390/toxins2051166

Menezes, M., Branco, S., Miotto, M.C., Alves-de-Souza, C., 2018. The Genus Alexandrium (Dinophyceae, Dinophyta) in Brazilian Coastal Waters. Front. Mar. Sci. 5, 1-13. https://doi.org/10.3389/fmars.2018.00421

Mitra, A., Flynn, K.J., Burkholder, J.M., Berge, T., Calbet, A., Raven, J.A., Granéli, E., Glibert, P.M., Hansen, P.J., Stoecker, D.K., Thingstad, F., Tillmann, U., Våge, S., Wilken, S., Zubkov, M. V., 2014. The role of mixotrophic protists in the biological carbon pump. Biogeosciences 11, 995-1005. https://doi.org/10.5194/bg-11-995-2014

Moreira-González, A.R., Fernandes, L.F., Uchida, H., Uesugi, A., Suzuki, T., Chomérat, N., Bilien, G., Mafra, L.L., 2019. Variations in morphology, growth, and toxicity among 
strains of the Prorocentrum lima species complex isolated from Cuba and Brazil. J. Appl. Phycol. 31, 519-532. https://doi.org/10.1007/s10811-018-1587-y

1348

1349

1350

1351

1352

1353

1354

1355

1356

1357

1358

1359

1360

1361

1362

1363

1364

1365

1366

1367

1368

1369

1370

1371

1372

1373

1374

1375

1376

1377

1378

1379

1380

1381

1382

1383

1384

1385

1386

1387

Mortensen, S., Strand, Å., Bodvin, T., Alfjorden, A., Skår, C., Jelmert, A., Aspán, A., Sælemyr, L., Naustvoll, L., Albretsen, J., 2016. Summer mortalities and detection of ostreid herpesvirus microvariant in Pacific oyster Crassostrea gigas in Sweden and Norway. Dis. Aquat. Organ. 117, 171-176. https://doi.org/10.3354/dao02944

Nam, K.-W., Jeung, H.-D., Song, J.-H., Park, K.-H., Choi, K.-S., Park, K.-I., 2018. High parasite burden increases the surfacing and mortality of the Manila clam (Ruditapes philippinarum) in intertidal sandy mudflats on the west coast of Korea during hot summer. Parasit. Vectors 11, 42. https://doi.org/10.1186/s13071-018-2620-3

Nascimento, S.M., Corrêa, E. V., Menezes, M., Varela, D., Paredes, J., Morris, S., 2012. Growth and toxin profile of Ostreopsis cf. ovata (Dinophyta) from Rio de Janeiro, Brazil. Harmful Algae 13, 1-9. https://doi.org/10.1016/j.hal.2011.09.008

Navarro, J.M., González, K., Cisternas, B., López, J. a, Chaparro, O.R., Segura, C.J., Córdova, M., Suárez-Isla, B., Fernandez-Reiriz, M.J., Labarta, U., 2014. Contrasting physiological responses of two populations of the razor clam Tagelus dombeii with different histories of exposure to Paralytic Shellfish Poisoning (PSP). PLoS One 9, e105794. https://doi.org/10.1371/journal.pone.0105794

Nell, J., 2001. The history of oyster farming in Australia. Mar. Fish. Rev. 63, 14-25.

Neves, R.A.F., Santiago, T.C., Carvalho, W.F., Silva, E. dos S., da Silva, P.M., Nascimento, S.M., 2019. Impacts of the toxic benthic dinoflagellate Prorocentrum lima on the brown mussel Perna perna: Shell-valve closure response, immunology, and histopathology. Mar. Environ. Res. 146, 35-45. https://doi.org/10.1016/j.marenvres.2019.03.006

Núñez-Vázquez, E.J., Gárate-Lizarraga, I., Band-Schmidt, C.J., Cordero-Tapia, A., LopezCortes, D.J., Sandoval, F.E.H., Heredia-Tapia, A., Bustillos-Guzman, J.J., 2011. Impact of Harmful Algal Blooms on wild and cultured animals in the Gulf of California. J. Environ. Biol. 32, 413-423.

Oehrens Kissner, E., Doldan, M., Zaidman, P., Morsan, E., Kroeck, M., 2014. Bonamiosis status in natural Ostrea puelchana beds in San Matías Gulf (Patagonia, Argentina), 14 years after an epizootic. Dis. Aquat. Organ. 110, 135-142. https://doi.org/10.3354/dao02707

Paillard, C., 2004. A short-review of brown ring disease, a vibriosis affecting clams, Ruditapes philippinarum and Ruditapes decussatus. Aquat. Living Resour. 17, 467-475. https://doi.org/10.1051/alr:2004053

Panel, E., Health, A., 2015. Oyster mortality. EFSA J. 13, 4122. https://doi.org/10.2903/j.efsa.2015.4122

Park, K.-I., Paillard, C., Le Chevalier, P., Choi, K.-S., 2006. Report on the occurrence of brown ring disease (BRD) in Manila clam, Ruditapes philippinarum, on the west coast of Korea. Aquaculture 255, 610-613. https://doi.org/10.1016/j.aquaculture.2005.12.011

Park, K.-I., Tsutsumi, H., Hong, J.-S., Choi, K.-S., 2008. Pathology survey of the short-neck clam Ruditapes philippinarum occurring on sandy tidal flats along the coast of Ariake Bay, Kyushu, Japan. J. Invertebr. Pathol. 99, 212-219. 
https://doi.org/10.1016/j.jip.2008.06.004

1389

1390

1391

1392

1393

1394

1395

1396

1397

1398

1399

1400

1401

1402

1403

1404

1405

1406

1407

1408

1409

1410

1411

1412

1413

1414

1415

1416

1417

1418

1419

1420

1421

1422

1423

1424

1425

1426

1427

1428

1429

Paul-Pont, I., Dhand, N.K., Whittington, R.J., 2013. Spatial distribution of mortality in Pacific oysters Crassostrea gigas: reflection on mechanisms of OsHV-1 transmission. Dis. Aquat. Organ. 105, 127-138. https://doi.org/10.3354/dao02615

Paul-Pont, I., Evans, O., Dhand, N.K., Rubio, A., Coad, P., Whittington, R.J., 2014. Descriptive epidemiology of mass mortality due to Ostreid herpesvirus-1 (OsHV-1) in commercially farmed Pacific oysters (Crassostrea gigas) in the Hawkesbury River estuary, Australia. Aquaculture 422-423, 146-159. https://doi.org/10.1016/j.aquaculture.2013.12.009

Perkins, F.O., Wolf, P.H., 1976. Fine structure of Marteilia sydneyi sp. n.- haplosporidan pathogen of Australian oysters. J. Parasitol. 62, 528-538.

Persson, A., Smith, B.C., Alix, J.H., Senft-Batoh, C., Wikfors, G.H., 2012. Toxin content differs between life stages of Alexandrium fundyense (Dinophyceae). Harmful Algae 19, 101-107. https://doi.org/10.1016/j.hal.2012.06.006

Petton, B., Bruto, M., James, A., Labreuche, Y., Alunno-Bruscia, M., Le Roux, F., 2015. Crassostrea gigas mortality in France: the usual suspect, a herpes virus, may not be the killer in this polymicrobial opportunistic disease. Front. Microbiol. 6, 1-10. https://doi.org/10.3389/fmicb.2015.00686

Pichot, Y., Comps, M., Tige, G., Grizel, H., Rabouin, M., 1980. Recherches sur Bonamia ostreae, gen. n. sp. n., parasite nouveau de l'huître plate Ostrea edulis L. Rev. des Trav. l'Institut des Pêches Marit. 43, 131-140.

Pomati, F., Rossetti, C., Calamari, D., Neilan, B.A., 2003. Effects of Saxitoxin (STX) and Veratridine on bacterial Na+- K+ fluxes: a Prokaryote-based STX bioassay. Appl. Environ. Microbiol. 69, 7371-7376. https://doi.org/10.1128/AEM.69.12.7371

Pousse, É., Flye-Sainte-Marie, J., Alunno-Bruscia, M., Hégaret, H., Jean, F., 2018. Sources of paralytic shellfish toxin accumulation variability in the Pacific oyster Crassostrea gigas. Toxicon 144, 14-22. https://doi.org/10.1016/j.toxicon.2017.12.050

Prado-Alvarez, M., Flórez-Barrós, F., Méndez, J., Fernandez-Tajes, J., 2013. Effect of okadaic acid on carpet shell clam (Ruditapes decussatus) haemocytes by in vitro exposure and harmful algal bloom simulation assays. Cell Biol. Toxicol. 29, 189-197. https://doi.org/10.1007/s10565-013-9246-1

Prado-Alvarez, M., Flórez-Barrós, F., Sexto-Iglesias, A., Méndez, J., Fernandez-Tajes, J., 2012. Effects of okadaic acid on haemocytes from Mytilus galloprovincialis: A comparison between field and laboratory studies. Mar. Environ. Res. 81, 90-93. https://doi.org/10.1016/j.marenvres.2012.08.011

Prego-Faraldo, M., Valdiglesias, V., Laffon, B., Mendez, J., Eirin-Lopez, J., 2016. Early Genotoxic and Cytotoxic Effects of the Toxic Dinoflagellate Prorocentrum lima in the Mussel Mytilus galloprovincialis. Toxins (Basel). 8, 159. https://doi.org/10.3390/toxins8060159

Prego-Faraldo, M.V., Valdiglesias, V., Laffon, B., Eirín-López, J.M., Méndez, J., 2015. In Vitro Analysis of Early Genotoxic and Cytotoxic Effects of Okadaic Acid in Different Cell Types of the Mussel Mytilus galloprovincialis. J. Toxicol. Environ. Heal. Part A 78, 
1431

1432

1433

1434

1435

1436

1437

1438

1439

1440

1441

1442

1443

1444

1445

1446

1447

1448

1449

1450

1451

1452

1453

1454

1455

1456

1457

1458

1459

1460

1461

1462

1463

1464

1465

1466

1467

1468

1469

1470

Proença, L., Tamanaha, M., Souza, N., 2001. The toxic dinoflagellate Gymnodinium catenatum Graham in southern Brazilian waters: Occurrence, pigments and toxins. Atlântica 23, 59-65.

Proença, L.A.O., Schramm, M.A., M.S.Tamanaha, Alves, T.P., 2007. Diarrhoetic shellfish poisoning (DSP) outbreak in Subtropical Southwest Atlantic. Harmful Algae News 1920.

Queiroga, F.R., Marques-Santos, L.F., Hégaret, H., Soudant, P., Farias, N.D., Schlindwein, A.D., da Silva, P.M., 2013. Immunological responses of the mangrove oysters Crassostrea gasar naturally infected by Perkinsus sp. in the Mamanguape Estuary, Paraíba state (Northeastern, Brazil). Fish Shellfish Immunol. 35, 319-327. https://doi.org/10.1016/j.fsi.2013.04.034

Queiroga, F.R., Vianna, R.T., Vieira, C.B., Farias, N.D., Da Silva, P.M., 2015. Parasites infecting the cultured oyster Crassostrea gasar (Adanson, 1757) in Northeast Brazil. Parasitology 142, 756-766. https://doi.org/10.1017/S0031182014001863

Ramilo, A., González, M., Carballal, M., Darriba, S., Abollo, E., Villalba, A., 2014. Oyster parasites Bonamia ostreae and B. exitiosa co-occur in Galicia (NW Spain): spatial distribution and infection dynamics. Dis. Aquat. Organ. 110, 123-133. https://doi.org/10.3354/dao02673

Rasmussen, S.A., Andersen, A.J.C., Andersen, N.G., Nielsen, K.F., Hansen, P.J., Larsen, T.O., 2016. Chemical Diversity, Origin, and Analysis of Phycotoxins. J. Nat. Prod. 79, 662-673. https://doi.org/10.1021/acs.jnatprod.5b01066

Rasmussen, S.A., Binzer, S.B., Hoeck, C., Meier, S., de Medeiros, L.S., Andersen, N.G., Place, A., Nielsen, K.F., Hansen, P.J., Larsen, T.O., 2017. Karmitoxin: An AmineContaining Polyhydroxy-Polyene Toxin from the Marine Dinoflagellate Karlodinium armiger. J. Nat. Prod. 80, 1287-1293. https://doi.org/10.1021/acs.jnatprod.6b00860

Reid, H.I., Duncan, H.L., Laidler, L.A., Hunter, D., Birkbeck, T.H., 2003. Isolation of Vibrio tapetis from cultivated Atlantic halibut (Hippoglossus hippoglossus L.). Aquaculture 221, 65-74. https://doi.org/10.1016/S0044-8486(03)00060-7

Renault, T., 1996. Appearance and spread of diseases among bivalve molluscs in the northern hemisphere in relation to international trade. Rev. Sci. Tech. l'Office Int. des Epizoot. $15,551-561$.

Rhodes, L., Smith, K.F., 2019. A checklist of the benthic and epiphytic marine dinoflagellates of New Zealand, including Rangitāhua/Kermadec Islands. New Zeal. J. Mar. Freshw. Res. 53, 258-277. https://doi.org/10.1080/00288330.2018.1492425

Rhodes, L.L., Smith, K.F., MacKenzie, L., Moisan, C., 2019. Checklist of the planktonic marine dinoflagellates of New Zealand. New Zeal. J. Mar. Freshw. Res. 0, 1-16. https://doi.org/10.1080/00288330.2019.1626746

Rivera, I.N.G., Souza, K.M.C., Souza, C.P., Lopes, R.M., 2013. Free-Living and PlanktonAssociated Vibrios: Assessment in Ballast Water, Harbor Areas, and Coastal Ecosystems in Brazil. Front. Microbiol. 3, 1-8. https://doi.org/10.3389/fmicb.2012.00443 
Robledo, J.A.F., Vasta, G.R., Record, N.R., 2014. Protozoan Parasites of Bivalve Molluscs: Literature Follows Culture. PLoS One 9, e100872. https://doi.org/10.1371/journal.pone.0100872

Rolton, A., Soudant, P., Vignier, J., Pierce, R., Henry, M., Shumway, S.E., Bricelj, V.M., Volety, A.K., 2015. Susceptibility of gametes and embryos of the eastern oyster, Crassostrea virginica, to Karenia brevis and its toxins. Toxicon 99, 6-15. https://doi.org/10.1016/j.toxicon.2015.03.002

Ruano, F., Batista, F.M., Arcangeli, G., 2015. Perkinsosis in the clams Ruditapes decussatus and $R$. philippinarum in the Northeastern Atlantic and Mediterranean Sea: A review. J. Invertebr. Pathol. 131, 58-67. https://doi.org/10.1016/j.jip.2015.07.015

Samain, J., 2011. Review and perspectives of physiological mechanisms underlying genetically-based resistance of the Pacific oyster Crassostrea gigas to summer mortality. Aquat. Living Resour. 24, 227-236. https://doi.org/10.1051/alr/2011144

Samain, J.F., McCombie, H., 2007. Mortalités estivales de l'huitre creuse Crassostrea gigas: Défi Morest, Editions Q. ed.

Santiago, M.F., Silva-Cunha, M. da G.G. da, Neumann-Leitão, S., Costa, K.M.P. da, Palmeira, G.C.B., Porto Neto, F. de F., Nunes, F.S., 2010. Phytoplankton dynamics in a highly eutrophic estuary in tropical Brazil. Brazilian J. Oceanogr. 58, 189-205. https://doi.org/10.1590/S1679-87592010000300002

Scardua, M., Vianna, R., Duarte, S., Farias, N., Correia, M., dos Santos, H., da Silva, P., 2017. Growth, mortality and susceptibility of oyster Crassostrea spp. to Perkinsus spp. infection during on-growing in northeast Brazil. Rev. Bras. Parasitol. Veterinária 26, 401-410. https://doi.org/10.1590/s1984-29612017061

Schmitt, P., Lorgeril, J. de, Gueguen, Y., Destoumieux-Garzón, D., Bachère, E., 2012a. Expression, tissue localization and synergy of antimicrobial peptides and proteins in the immune response of the oyster Crassostrea gigas. Dev. Comp. Immunol. 37, 363-370. https://doi.org/10.1016/j.dci.2012.01.004

Schmitt, P., Rosa, R.D., Destoumieux-Garzón, D., 2016. An intimate link between antimicrobial peptide sequence diversity and binding to essential components of bacterial membranes. Biochim. Biophys. Acta - Biomembr. 1858, 958-970. https://doi.org/10.1016/j.bbamem.2015.10.011

Schmitt, P., Rosa, R.D., Duperthuy, M., de Lorgeril, J., Bachère, E., Destoumieux-Garzón, D., 2012b. The antimicrobial defense of the Pacific oyster, Crassostrea gigas. How diversity may compensate for scarcity in the regulation of resident/pathogenic microflora. Front. Microbiol. 3, 1-17. https://doi.org/10.3389/fmicb.2012.00160

Segarra, A., Pépin, J.F., Arzul, I., Morga, B., Faury, N., Renault, T., 2010. Detection and description of a particular Ostreid herpesvirus 1 genotype associated with massive mortality outbreaks of Pacific oysters, Crassostrea gigas, in France in 2008. Virus Res. 153, 92-99.

Sellner, K.G., Doucette, G.J., Kirkpatrick, G.J., 2003. Harmful algal blooms: causes, impacts and detection. J. Ind. Microbiol. Biotechnol. 30, 383-406. https://doi.org/10.1007/s10295-003-0074-9 
Seymour, J.R., Amin, S.A., Raina, J.-B., Stocker, R., 2017. Zooming in on the phycosphere: the ecological interface for phytoplankton-bacteria relationships. Nat. Microbiol. 2, 17065. https://doi.org/10.1038/nmicrobiol.2017.65

Shumway, S.E., 1990. A review of the effects of algal blooms on shellfish and aquaculture. J. World Aquac. Soc. 21, 65-104.

Simó, R., 2001. Production of atmospheric sulfur by oceanic plankton: biogeochemical, ecological and evolutionary links. Trends Ecol. Evol. 16, 287-294. https://doi.org/10.1016/S0169-5347(01)02152-8

Simões, E., Vieira, R.C., Schramm, M.A., Mello, D.F., De Almeida Pontinha, V., da Silva, P.M., Barracco, M.A., 2015. Impact of harmful algal blooms (Dinophysis acuminata) on the immune system of oysters and mussels from Santa Catarina, Brazil. J. Mar. Biol. Assoc. United Kingdom 95, 773-781. https://doi.org/10.1017/S0025315414001702

Sokolova, I.M., 2009. Apoptosis in molluscan immune defense. Invertebr. Surviv. J. 6, 49-58.

Song, L., Wang, L., Qiu, L., Zhang, H., 2010. Bivalve Immunity, in: Söderhäll, K. (Ed.), Invertebrate Immunity. Springer Science+Business Media, LLC. Landes Bioscience, USA, NY, USA, pp. 44-65.

Spiers, Z., Gabor, M., Fell, S., Carnegie, R., Dove, M., O’Connor, W., Frances, J., Go, J., Marsh, I., Jenkins, C., 2014. Longitudinal study of winter mortality disease in Sydney rock oysters Saccostrea glomerata. Dis. Aquat. Organ. 110, 151-164. https://doi.org/10.3354/dao02629

Tavares, J., Proença, L.A.O., Odebrecht, C., 2009. Assessing the harmful microalgae occurrence and temporal variation in a coastal aquaculture area, southern Brazil. Harmful Microalgae A Mar. Aquac. Area 31, 129-144.

Tibiriçá, C.E.J. de A., Fernandes, L.F., Mafra Junior, L.L., 2015. Seasonal and spatial patterns of toxigenic species of Dinophysis and Pseudo-nitzschia in a subtropical Brazilian estuary. Brazilian J. Oceanogr. 63, 17-32. https://doi.org/10.1590/S167987592015071906301

Tillmann, U., 2003. Kill and eat your predator: a winning strategy of the planktonic flagellate Prymnesium parvum. Aquat. Microb. Ecol. 32, 73-84. https://doi.org/10.3354/ame032073

Tillmann, U., Alpermann, T., John, U., Cembella, A., 2008. Allelochemical interactions and short-term effects of the dinoflagellate Alexandrium on selected photoautotrophic and heterotrophic protists. Harmful Algae 7, 52-64. https://doi.org/10.1016/j.hal.2007.05.009

Tillmann, U., John, U., 2002. Toxic effects of Alexandrium spp. on heterotrophic dinoflagellates: an allelochemical defence mechanism independent of PSP-toxin content. Mar. Ecol. Prog. Ser. 230, 47-58. https://doi.org/10.3354/meps230047

Tillmann, U., John, U., Cembella, A., 2007. On the allelochemical potency of the marine dinoflagellate Alexandrium ostenfeldii against heterotrophic and autotrophic protists. J. Plankton Res. 29, 527-543. https://doi.org/10.1093/plankt/fbm034

Travers, M.-A., Boettcher Miller, K., Roque, A., Friedman, C.S., 2015. Bacterial diseases in marine bivalves. J. Invertebr. Pathol. 131, 11-31. 
https://doi.org/10.1016/j.jip.2015.07.010

1555

1556

1557

1558

1559

1560

1561

1562

1563

1564

1565

1566

1567

1568

1569

1570

1571

1572

1573

1574

1575

1576

1577

1578

1579

1580

1581

1582

1583

1584

1585

1586

1587

1588

Tran, D., Haberkorn, H., Soudant, P., Ciret, P., Massabuau, J.-C., 2010. Behavioral responses of Crassostrea gigas exposed to the harmful algae Alexandrium minutum. Aquaculture 298, 338-345. https://doi.org/10.1016/j.aquaculture.2009.10.030

Turner, L.M., Alsterberg, C., Turner, A.D., Girisha, S.K., Rai, A., Havenhand, J.N., Venugopal, M.N., Karunasagar, I., Godhe, A., 2016. Pathogenic marine microbes influence the effects of climate change on a commercially important tropical bivalve. Sci. Rep. 6, 32413. https://doi.org/10.1038/srep32413

Vargas-Albores, F., Barracco, M.A., 2001. Defense mechanisms in bivalve mollusks, with emphasis in pectinids, in: Maeda-Martínez, A. (Ed.), Los Moluscos Pectínidos de Iberoamérica: Ciencia y Acuicultura. pp. 127-146.

Villalba, A., Gestal, C., Casas, S.S.M., Figueras, A., 2011. Perkinsosis en moluscos, in: Figueras, A., Novoa, B. (Eds.), Enfermidades de Moluscos Bivalves de Interés En Acuicutura. Publicaciones Científicas y Tecnológicas de la Fundación Observatorio Español de Acuicultura, Madrid, pp. 183-242.

Waki, T., Takahashi, M., Eki, T., Hiasa, M., Umeda, K., Karakawa, N., Yoshinaga, T., 2018. Impact of Perkinsus olseni infection on a wild population of Manila clam Ruditapes philippinarum in Ariake Bay, Japan. J. Invertebr. Pathol. 153, 134-144. https://doi.org/10.1016/j.jip.2018.03.001

Wells, M.L., Trainer, V.L., Smayda, T.J., Karlson, B.S.O., Trick, C.G., Kudela, R.M., Ishikawa, A., Bernard, S., Wulff, A., Anderson, D.M., Cochlan, W.P., 2015. Harmful algal blooms and climate change: Learning from the past and present to forecast the future. Harmful Algae 49, 68-93. https://doi.org/10.1016/j.hal.2015.07.009

Yim, J.H., Kim, S.J., Ahn, S.H., Lee, C.K., Rhie, K.T., Lee, H.K., 2004. Antiviral Effects of Sulfated Exopolysaccharide from the Marine Microalga Gyrodinium impudicum Strain KG03. Mar. Biotechnol. 6, 17-25. https://doi.org/10.1007/s10126-003-0002-z

Zannella, C., Mosca, F., Mariani, F., Franci, G., Folliero, V., Galdiero, Marilena, Tiscar, P.G., Galdiero, Massimiliano, 2017. Microbial Diseases of Bivalve Mollusks: Infections, Immunology and Antimicrobial Defense. Mar. Drugs 15, 182. https://doi.org/10.3390/md15060182

Zhang, J., Li, Y., Ren, W., Cai, Y., 2010. Studies on phytoplanktons carrying and spreading AVNV. J. Fish. Chine 34, 1254-1259.

Zhou, J., Richlen, M.L., Sehein, T.R., Kulis, D.M., Anderson, D.M., Cai, Z., 2018. Microbial Community Structure and Associations During a Marine Dinoflagellate Bloom. Front. Microbiol. 9, 1-21. https://doi.org/10.3389/fmicb.2018.01201 


\section{Figure captions}

Figure 1. Summary of the different mechanisms reported or supposed to be involved in the effects of harmful algal blooms (HABs) upon bivalve diseases, according to the literature. Arrows indicate increase or decrease of the adjoining process, + and - indicate positive and negative effect, respectively, on the pathogen transmission or proliferation. A. When reaching bivalves, HABs and compounds produced can affect hemocyte functions, either by inhibiting them $(\downarrow)$ causing immunosuppression and favor pathogen proliferation (+), or, conversely, stimulate immune responses $(\uparrow)$, which could inhibit pathogen proliferation (-). HABs can decrease filtration rates $(\downarrow)$ that may in turn decrease pathogens entry and reduce its transmission (-). HABs can cause tissue and organs lesions, altering physiological status $(\downarrow)$ and therefore decreasing defense against pathogens, that can proliferate $(+)$. Pathogen in bivalve tissues could also be affected by HAB compounds directly, altering its viability or pathogenicity (-). B. HABs and compounds produced can also interact directly with pathogens in the seawater, altering pathogen integrity or putatively acting as pathogen carrier, therefore preventing (-) or favouring (+) pathogen transmission.

Figure 2. Hypothetical scenarios of the long-term effect of HABs on disease dynamics in bivalves, proposed based on short-term experimental studies. The evolution of the HAB (red), and of the pathogen infection or the mortality rate (without the effect of HAB: solid blue line; with the effect of $\mathrm{HAB}$ : interrupted blue line) are represented on the y-axis, according to a temporal scale, represented on the x-axis. A. Proposed effect of Alexandrium catenella bloom on herpesvirus OsHV-1 infection in oyster Crassostrea gigas spat (from Lassudrie et al., 2015a). B. Proposed effect of A. catenella on mortality associated with bacterium Vibrio tasmaniensis infection in oyster C. gigas spat (from Abi-Khalil et al., 2016). C. Proposed effect of A.fundyense on protozoan parasite Perkinsus marinus infection in oyster C. virginica also infested with trematodes (from Lassudrie et al., 2015b). D. Proposed effect of Karenia selliformis on protozoan parasite P. olseni infection in clam Ruditapes philippinarum (from da Silva et al., 2008). 
Table 1: Main bivalve diseases (mainly OIE notifiable diseases), associated pathogen, distribution and temporal dynamics, main marine HAB genera hypothetically co-occurring with disease (HABs reported to occur in regions and seasons where and when disease also occur, suggesting that both HABs and disease co-occur), and marine HAB species reported to co-occur with disease outbreaks in the field.

\begin{tabular}{|c|c|c|c|c|c|c|c|c|}
\hline $\begin{array}{l}\text { Bivalve } \\
\text { species }\end{array}$ & Disease & Pathogen & Effect & Distribution & Seasonal dynamic & $\begin{array}{l}\text { Reference for } \\
\text { disease reports }\end{array}$ & $\begin{array}{l}\text { Hypothetical co-occurrence of main HAB } \\
\text { genera* }\end{array}$ & $\begin{array}{l}\text { Reported } \\
\text { co- } \\
\text { occurrence } \\
\text { of HABs } \\
\text { with disease } \\
\text { outbreak }\end{array}$ \\
\hline $\begin{array}{l}\text { Crassostrea } \\
\text { gigas } \\
\text { (juvenile-spat) }\end{array}$ & $\begin{array}{l}\text { Pacific } \\
\text { Oyster } \\
\text { Mortality } \\
\text { Syndrome } \\
\text { (POMS) }\end{array}$ & $\begin{array}{l}\text { OsHV-1 } \\
\text { microvariants } \\
\text { (virus) and } \\
\text { Vibrio spp. } \\
\text { (bacteria) }\end{array}$ & Lethal & $\begin{array}{l}\text { Southern } \\
\text { and Western } \\
\text { Europe }\end{array}$ & Summer to fall & $\begin{array}{l}\text { (Barbosa } \\
\text { Solomieu et al., } \\
\text { 2015) }\end{array}$ & $\begin{array}{l}\text { Alexandrium, Pseudo-nitzschia, Dinophysis, } \\
\text { Ostreopsis, Azadinium, Vulcanodinium, } \\
\text { Protoceratium, Lingulodinium, Gonyaulax, } \\
\text { Karlodinium }\end{array}$ & $\begin{array}{l}\text { Alexandrium } \\
\text { spp. (Abi- } \\
\text { Khalil et al., } \\
\text { 2016) }\end{array}$ \\
\hline $\begin{array}{l}\text { Crassostrea } \\
\text { gigas } \\
\text { (juvenile-spat) }\end{array}$ & $\begin{array}{l}\text { Pacific } \\
\text { Oyster } \\
\text { Mortality } \\
\text { Syndrome } \\
\text { (POMS) }\end{array}$ & $\begin{array}{l}\text { OsHV-1 } \\
\text { microvariants } \\
\text { (virus) and } \\
\text { Vibrio spp. } \\
\text { (bacteria) }\end{array}$ & Non-lethal & $\begin{array}{l}\text { Brazil } \\
\text { (South } \\
\text { coast) }\end{array}$ & Unknown & $\begin{array}{l}\text { (Mello et al., } \\
\text { 2018) }\end{array}$ & $\begin{array}{l}\text { Dinophysis spp., Gymnodinium, Pseudo- } \\
\text { nitzschia, Alexandrium, Prorocentrum, } \\
\text { Chatonella, Heterosigma, Fibrocapsa (Branco } \\
\text { et al., 2019; Cuellar-Martinez et al., 2018; } \\
\text { Mafra et al., 2015, 2006; Menezes et al., 2018; } \\
\text { Moreira-González et al., 2019; Proença et al., } \\
\text { 2001, 2007; Simões et al., 2015; Tavares et } \\
\text { al., 2009; Tibiriçá et al., 2015) }\end{array}$ & NA \\
\hline $\begin{array}{l}\text { Crassostrea } \\
\text { gigas }\end{array}$ & Perkinsosis & $\begin{array}{l}\text { Perkinsus } \\
\text { marinus } \\
\text { (protozoan } \\
\text { parasite) }\end{array}$ & Lethal & $\begin{array}{l}\text { Mexico } \\
\text { (Gulf of } \\
\text { California) }\end{array}$ & Unknown & $\begin{array}{l}\text { (Enríquez- } \\
\text { Espinoza et al., } \\
2010)\end{array}$ & $\begin{array}{l}\text { Margalefidinium, Pseudo-nitzschia, } \\
\text { Prorocentrum, Gymnodinium, Chatonella } \\
\text { Akashiwo, Heterosigma (Núñez-Vázquez et } \\
\text { al., 2011) }\end{array}$ & NA \\
\hline $\begin{array}{l}\text { Crassostrea } \\
\text { virginica }\end{array}$ & $\begin{array}{l}\text { Dermo / } \\
\text { Perkinsosis }\end{array}$ & $\begin{array}{l}\text { Perkinsus } \\
\text { marinus } \\
\text { (protozoan } \\
\text { parasite) }\end{array}$ & Lethal & $\begin{array}{l}\text { USA (East } \\
\text { coast) }\end{array}$ & $\begin{array}{l}\text { Maximum in summer } \\
\text { and autumn }\end{array}$ & $\begin{array}{l}\text { (Burreson and } \\
\text { Ragone-Calvo, } \\
\text { 1996; Ford and } \\
\text { Smolowitz, } \\
\text { 2007) }\end{array}$ & $\begin{array}{l}\text { Alexandrium, Karenia, Margalefidinium } \\
\text { Karlodinium, Pseudo-nitzschia, } \\
\text { Prorocentrum, Prymnesium, Dinophysis }\end{array}$ & NA \\
\hline $\begin{array}{l}\text { Crassostrea } \\
\text { corteziensis }\end{array}$ & Perkinsosis & $\begin{array}{l}\text { Perkinsus } \\
\text { marinus } \\
\text { (protozoan } \\
\text { parasite) }\end{array}$ & Non-lethal & $\begin{array}{l}\text { Mexico } \\
\text { (Pacific } \\
\text { coast) }\end{array}$ & Maximum in summer & $\begin{array}{l}\text { (Cáceres- } \\
\text { Martínez et al., } \\
\text { 2016) }\end{array}$ & $\begin{array}{l}\text { Margalefidinium Pseudo-nitzschia, } \\
\text { Prorocentrum, Pyrodinium, } \\
\text { Dinophysis, Gambierdiscus }\end{array}$ & NA \\
\hline
\end{tabular}




\begin{tabular}{|c|c|c|c|c|c|c|c|c|}
\hline $\begin{array}{l}\text { Crassostrea } \\
\text { gasar }\end{array}$ & Perkinsosis & $\begin{array}{l}\text { Perkinsus } \\
\text { marinus and } \\
\text { P. beihaiensis } \\
\text { (protozoan } \\
\text { parasites) }\end{array}$ & Sub-lethal & $\begin{array}{l}\text { Brazil } \\
\text { (Northeast } \\
\text { coast) }\end{array}$ & $\begin{array}{l}\text { Sergipe State: } \\
\text { Maximum in summer } \\
\text { and autumn } \\
\text { Other States: no } \\
\text { seasonal pattern }\end{array}$ & $\begin{array}{l}\text { (da Silva et al., } \\
\text { 2014; Queiroga } \\
\text { et al., 2015, } \\
\text { 2013) }\end{array}$ & $\begin{array}{l}\text { Nitzschia, Dinophysis, Alexandrium, } \\
\text { Ostreopsis, Prorocentrum, Gambierdiscus } \\
\text { (Aquino et al., 2015; De Carli, 2014; Jales et } \\
\text { al., 2013; Machado et al., 2018; Menezes et } \\
\text { al., 2018; Nascimento et al., 2012; Santiago et } \\
\text { al., 2010) ** }\end{array}$ & NA \\
\hline Ostrea edulis & $\begin{array}{l}\text { Digestive } \\
\text { gland } \\
\text { disease }\end{array}$ & $\begin{array}{l}\text { Marteilia } \\
\text { refringens } \\
\text { (protozoan } \\
\text { parasite) }\end{array}$ & Lethal & Europe & $\begin{array}{l}\text { Maximum in summer } \\
\left(>17^{\circ} \mathrm{C}\right) \text {. Winter and } \\
\text { early spring: absence or } \\
\text { few parasites. }\end{array}$ & $\begin{array}{l}\text { (Berthe et al., } \\
\text { 2004; Carrasco } \\
\text { et al., 2015) }\end{array}$ & $\begin{array}{l}\text { Alexandrium., Pseudo-nitzschia., Dinophysis, } \\
\text { Ostreopsis, Azadinium, Vulcanodinium, } \\
\text { Protoceratium, Lingulodinium, Gonyaulax, } \\
\text { Karlodinium }\end{array}$ & NA \\
\hline Ostrea edulis & $\begin{array}{l}\text { Microcell } \\
\text { disease }\end{array}$ & $\begin{array}{l}\text { Bonamia } \\
\text { ostrea } \\
\text { (protozoan } \\
\text { parasite) }\end{array}$ & Lethal & Europe & $\begin{array}{l}\text { Unclear. } \\
\text { Maximum prevalence } \\
\text { in winter. }\end{array}$ & $\begin{array}{l}\text { (Arzul and } \\
\text { Carnegie, 2015) }\end{array}$ & $\begin{array}{l}\text { Alexandrium., Pseudo-nitzschia., Dinophysis, } \\
\text { Ostreopsis, Azadinium, Vulcanodinium, } \\
\text { Protoceratium, Lingulodinium, Gonyaulax, } \\
\text { Karlodinium }\end{array}$ & $\overline{\mathrm{NA}}$ \\
\hline $\begin{array}{l}\text { Saccostrea } \\
\text { glomeraa }\end{array}$ & $\begin{array}{l}\text { Winter } \\
\text { mortality } \\
\text { disease }\end{array}$ & $\begin{array}{l}\text { Bonamia } \\
\text { roughleyi } \\
\text { (protozoan } \\
\text { parasite) }\end{array}$ & Lethal & $\begin{array}{l}\text { Australia } \\
\text { (East coast) }\end{array}$ & Winter and early spring & $\begin{array}{l}\text { (Dove et al., } \\
\text { 2013; Farley et } \\
\text { al., 1988; Spiers } \\
\text { et al., 2014) }\end{array}$ & $\begin{array}{l}\text { Alexandrium, Pseudo-nitzschia, Ostreopsis, } \\
\text { Gambierdiscus, Karlodinium, Prorocentrum, } \\
\text { Dinophysis, Amphidinium (Ajani et al., 2017, } \\
\text { 2013) }\end{array}$ & NA \\
\hline $\begin{array}{l}\text { Saccostrea } \\
\text { glomeraa }\end{array}$ & $\begin{array}{l}\text { Queensland } \\
\text { unknown } \\
\text { (QX) disease }\end{array}$ & $\begin{array}{l}\text { Marteillia } \\
\text { sydneyi } \\
\text { (protozoan } \\
\text { parasite) }\end{array}$ & Lethal & $\begin{array}{l}\text { Australia } \\
\text { (East coast) }\end{array}$ & Unclear & $\begin{array}{l}\text { (Adlard and } \\
\text { Wesche, 2005; } \\
\text { Green et al., } \\
\text { 2011; Nell, } \\
\text { 2001; Perkins } \\
\text { and Wolf, 1976) }\end{array}$ & $\begin{array}{l}\text { Alexandrium, Pseudo-nitzschia, Ostreopsis, } \\
\text { Gambierdiscus, Karlodinium, Prorocentrum, } \\
\text { Dinophysis, Amphidinium (Ajani et al., 2017, } \\
\text { 2013) }\end{array}$ & NA \\
\hline $\begin{array}{l}\text { Ruditapes } \\
\text { philippinarum }\end{array}$ & Perkinsosis & $\begin{array}{l}\text { Perkinsus } \\
\text { olseni } \\
\text { (protozoan } \\
\text { parasite) }\end{array}$ & $\begin{array}{l}\text { Lethal } \\
\text { (Portugal) } \\
\text { and sub- } \\
\text { lethal }\end{array}$ & $\begin{array}{l}\text { Europe } \\
\text { (Western } \\
\text { and South) }\end{array}$ & $\begin{array}{l}\text { Spain, and Portugal: } \\
\text { Maximum in spring } \\
\text { and summer. } \\
\text { France: no seasonality. }\end{array}$ & $\begin{array}{l}\text { (Ruano et al., } \\
\text { 2015; Villalba } \\
\text { et al., 2011) }\end{array}$ & $\begin{array}{l}\text { Alexandrium., Pseudo-nitzschia., Dinophysis, } \\
\text { Ostreopsis, Azadinium, Protoceratium, } \\
\text { Lingulodinium, Gonyaulax, Karlodinium }\end{array}$ & NA \\
\hline $\begin{array}{l}\text { Ruditapes } \\
\text { philippinarum }\end{array}$ & Perkinsosis & $\begin{array}{l}\text { Perkinsus } \\
\text { olseni } \\
\text { (protozoan } \\
\text { parasite) }\end{array}$ & Lethal & $\begin{array}{l}\text { East Asia } \\
\text { (Korea, } \\
\text { Japan, } \\
\text { China) }\end{array}$ & $\begin{array}{l}\text { South Korea: } \\
\text { Maximum late } \\
\text { summer; } \\
\text { Japan: Maximum in } \\
\text { summer and autumn }\end{array}$ & $\begin{array}{l}\text { (Choi and Park, } \\
\text { 2010; Waki et } \\
\text { al., 2018) }\end{array}$ & $\begin{array}{l}\text { Margalefidinium, Chatonella, Karenia, } \\
\text { Heterocapsa, } \\
\text { Gymnodinium, Heterosigma, Alexandrium, } \\
\text { Dinophysis, Prorocentrum, Gambierdiscus, } \\
\text { (Lee et al., 2013) }\end{array}$ & NA \\
\hline $\begin{array}{l}\text { Ruditapes } \\
\text { philippinarum }\end{array}$ & $\begin{array}{l}\text { Brown Ring } \\
\text { Disease } \\
\text { (BRD) }\end{array}$ & $\begin{array}{l}\text { Vibrio tapetis } \\
\text { (bacterium) }\end{array}$ & Lethal & $\begin{array}{l}\text { Korea and } \\
\text { Japan }\end{array}$ & Undertemined & $\begin{array}{l}\text { (Park et al., } \\
\text { 2008, 2006) }\end{array}$ & $\begin{array}{l}\text { Margalefidinium, Chatonella, Heterosigma, } \\
\text { Prorocentrum, Alexandrium, Akashiwo } \\
\text { (Lee et al., 2013) }\end{array}$ & NA \\
\hline $\begin{array}{l}\text { Ruditapes } \\
\text { philippinarum }\end{array}$ & $\begin{array}{l}\text { Brown Ring } \\
\text { Disease } \\
\text { (BRD) }\end{array}$ & $\begin{array}{l}\text { Vibrio tapetis } \\
\text { (bacterium) }\end{array}$ & Lethal & $\begin{array}{l}\text { France, } \\
\text { Spain }\end{array}$ & $\begin{array}{l}\text { Winter and spring: high } \\
\text { prevalence and } \\
\text { mortality }\end{array}$ & (Paillard, 2004) & $\begin{array}{l}\text { Alexandrium., Pseudo-nitzschia, Dinophysis, } \\
\text { Ostreopsis, Azadinium, Protoceratium, } \\
\text { Lingulodinium, Gonyaulax, Karlodinium }\end{array}$ & $\mathrm{NA}$ \\
\hline Most bivalves & Vibriosis & $\begin{array}{l}\text { Vibrio spp. } \\
\text { (bacteria) }\end{array}$ & $\begin{array}{l}\text { Lethal - } \\
\text { sub-lethal }\end{array}$ & Worldwide & $\begin{array}{l}\text { Variable and } \\
\text { undetermined }\end{array}$ & $\begin{array}{l}\text { (Travers et al., } \\
\text { 2015) }\end{array}$ & Potentially all HABs & NA \\
\hline
\end{tabular}

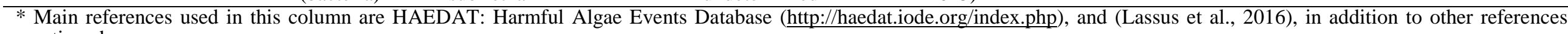

mentioned.

NA: Not available 
Table 2. Literature survey of the main studies reporting the effects of marine harmful algal blooms (HABs) on bivalve infectious diseases or pathogens. This table summarizes HAB effects on pathogen infection in bivalves, effects of direct HAB exposure to pathogens, effects of HABs and their combination with pathogens on bivalve physiological variables, and mechanisms identified to induce disease modulation. Individual effects of pathogens on bivalves are not listed here. Detailed hemocyte responses are listed in Table 4.

\begin{tabular}{|c|c|c|c|c|c|c|c|c|}
\hline $\begin{array}{l}\text { Bivalve } \\
\text { species; stage }\end{array}$ & $\begin{array}{l}\text { Pathogen } \\
\text { (infection } \\
\text { type; } \\
\text { conditions } \\
\text { compared) }\end{array}$ & $\begin{array}{l}\text { HAB species } \\
\text { Exposure type }\end{array}$ & $\begin{array}{l}\text { Effects of HAB } \\
\text { on pathogen } \\
\text { infection }\end{array}$ & $\begin{array}{l}\text { Direct } \\
\text { effects of } \\
\text { HAB on } \\
\text { pathogen }\end{array}$ & $\begin{array}{l}\text { Bivalve variables } \\
\text { studied }\end{array}$ & $\begin{array}{l}\text { Main effects of HAB and } \\
\text { combination with pathogen on } \\
\text { physiology of bivalves }\end{array}$ & $\begin{array}{l}\text { Identified reason } \\
\text { for disease } \\
\text { modulation }\end{array}$ & Reference \\
\hline $\begin{array}{l}\text { Crassostrea } \\
\text { virginica; } \\
\text { adult }\end{array}$ & $\begin{array}{l}\text { Perkinsus } \\
\text { marinus } \\
(\text { P.m.) } \\
\text { (natural; non } \\
\text { infected vs. } \\
\text { infected); } \\
\text { Bucephalus } \\
\text { sp. }(\text { B.) } \\
\text { (natural; non } \\
\text { infected vs. } \\
\text { infected) }\end{array}$ & $\begin{array}{l}\text { Alexandrium catenella } \\
(=A \text {. fundyense as } \\
\text { refered to in this } \\
\text { study })^{*} \\
\text { Simulated bloom } \\
2 \times 10^{3} \text { cells } \mathrm{mL}^{-1} 4 \\
\text { times a day } ; 3 \text { weeks }\end{array}$ & $\begin{array}{l}\text { Effect of HAB } \\
\text { alone: } \\
\text { Prevalence \& } \\
\text { intensity }(=, \\
P . m . \& B .) \\
\text { Combined effect } \\
\text { HAB-B: } \\
\text { Prevalence of } P . \\
m .(\uparrow) \text { in } B .- \\
\text { infected oysters, } \\
\text { Intensity }(=) .\end{array}$ & NA & $\begin{array}{l}\text { Viability; Condition } \\
\text { index; Circulating } \\
\text { hem.; } \\
\text { Histopathology; } \\
\text { Expression of } \\
\text { targeted immune- } \\
\text { related genes in } \\
\text { gills; Toxin } \\
\text { accumulation; } \\
\text { Pathogen infection }\end{array}$ & $\begin{array}{l}\text { Effect of HAB in } B \text {.-uninfected } \\
\text { bivalves } \\
\text { - Hem. infiltration (kidney) } \\
\text { Combined effect HAB - B.-infected } \\
\text { bivalves: } \\
\text { - Antagonistic: Suppression of hem. } \\
\text { inflammatory response to } B \text {. by } \\
\text { HAB (circulating hem. and } \\
\text { infiltration in tissues) } \\
\text { - Synergistic: Tissue degeneration } \\
\text { in adductor muscle }\end{array}$ & $\begin{array}{l}\text { Immunosuppression } \\
\text { caused by HAB } \\
\text { exposure combined } \\
\text { to physiological } \\
\text { weakness caused by } \\
B \text {. infection }\end{array}$ & $\begin{array}{l}\text { (Lassudrie } \\
\text { et al., } \\
2015 \text { b) }\end{array}$ \\
\hline $\begin{array}{l}\text { Crassostrea } \\
\text { gigas; juvenile }\end{array}$ & $\begin{array}{l}\text { Herpesvirus } \\
\text { OsHV-1 } \mu \text { Var } \\
\text { (experimentall } \\
\text { y by } \\
\text { cohabitation } \\
\text { (Exp.) or } \\
\text { naturally } \\
\text { (Nat.); non } \\
\text { infected } v s . \\
\text { infected) }\end{array}$ & $\begin{array}{l}\text { Alexandrium pacificum } \\
\text { (named A. catenella in } \\
\text { this study)* } \\
\text { Simulated bloom ;- } \\
3.5 \times 10^{2} \text { cells } \mathrm{mL}^{-1} \\
\text { continuously } ; 4 \text { days }\end{array}$ & $\begin{array}{l}\text { Exp.: } \\
\text { Prevalence }(\downarrow), \\
\text { Intensity }(=) ; \\
\text { Nat.: Prevalence } \\
(=), \text { Intensity }(\downarrow)\end{array}$ & NA & $\begin{array}{l}\text { Viability; Toxin } \\
\text { accumulation; } \\
\text { Pathogen infection }\end{array}$ & $\begin{array}{l}\text { Combined effect HAB-pathogen: } \\
\text { Toxin accumulation }(\downarrow)\end{array}$ & NA & $\begin{array}{l}\text { (Lassudrie } \\
\text { et al., } \\
\text { 2015a) }\end{array}$ \\
\hline $\begin{array}{l}\text { Crassostrea } \\
\text { gigas; juvenile }\end{array}$ & $\begin{array}{l}\text { Vibrio } \\
\text { tasmaniensis } \\
\text { LGP32. } \\
\text { (experimental } \\
\text { by injection; } \\
\text { infected } v s . \\
\text { non infected) }\end{array}$ & $\begin{array}{l}\text { Alexandrium pacificum } \\
\text { (named A. catenella in } \\
\text { this study)*, (A.p., PST } \\
\text { strain) } \\
\text { Alexandrium } \\
\text { tamarense*, (A.t., non- } \\
\text { PST strain) } \\
\text { Simulated bloom; } 1- \\
3 \times 10^{3} \text { cells } \mathrm{mL}^{-1}\end{array}$ & NA & NA & $\begin{array}{l}\text { Viability; Toxin } \\
\text { accumulation }\end{array}$ & $\begin{array}{l}\text { Effect of HAB for all infection } \\
\text { status: none } \\
\text { Combined effect HAB-pathogen: } \\
\text { Viability }(\downarrow \text { A.p.; }=\text { A.t. })\end{array}$ & NA & $\begin{array}{l}\text { (Abi- } \\
\text { Khalil et } \\
\text { al., 2016) }\end{array}$ \\
\hline
\end{tabular}




\begin{tabular}{|c|c|c|c|c|c|c|c|}
\hline $\begin{array}{l}\text { Mytilus edulis; } \\
\text { larva }\end{array}$ & $\begin{array}{l}\text { Vibrio } \\
\text { splendidus } \\
\text { (V.s.); Vibrio } \\
\text { coralliilyticus } \\
\text { (V.c.) } \\
\text { (experimentall } \\
\text { y by } \\
\text { incubation; } \\
\text { infected } v s \\
\text { non infected) }\end{array}$ & $\begin{array}{l}\text { Prorocentrum lima } \\
(\text { P.l. }) ; \text { Prorocentrum } \\
\text { micans }(\text { P.m. }) ; \\
\text { Alexandrium } \\
\text { ostenfeldii }(\text { A.o. }) ; \\
\text { Alexandrium minutum } \\
(\text { A.m. }) ; \text { Karenia } \\
\text { mikimotoi }(\text { K.m. }) ; \\
\text { Protoceratium } \\
\text { reticulatum }(P . r .) ; \\
\text { Prorocentrum } \\
\text { cordatum }(P . c .) \\
\text { Simulated bloom } ; 10^{2}, \\
5 \times 10^{2}, 2.5 \times 10^{3} \& \\
1.2 \times 10^{4} \text { cells } \mathrm{mL}^{-1} \text { once } \\
; 5 \text { days }\end{array}$ & NA & $\begin{array}{l}\text { Viability; Larval } \\
\text { development; } \\
\text { Phenoloxydase } \\
\text { activity (except for } \\
\text { A.m, A.o, P.r, with } \\
\text { V.s. and V.c., and } \\
\text { for P.m., K.m. with } \\
\text { V.s.) }\end{array}$ & $\begin{array}{l}\text { Effect of HAB (at highest } \\
\text { concentrations) for all infection } \\
\text { status: } \\
\text { - Larval viability and development } \\
\text { rate } \downarrow \text { (except } P . c . \text { ) } \\
\text { - Immune function: modulation of } \\
\text { phenoloxydase activity depending } \\
\text { on algal species ( } \uparrow P . c . \text { and P.m., } \downarrow \\
K . m . \text { and } P . l . \text { ) } \\
\text { Combined effect of HAB-pathogen: } \\
\text { none }\end{array}$ & NA & $\begin{array}{l}\text { (De Rijcke } \\
\text { et al., } \\
2016)\end{array}$ \\
\hline $\begin{array}{l}\text { Mytilus edulis; } \\
\text { adult }\end{array}$ & $\begin{array}{l}\text { Gymnophallid } \\
\text { ae trematodes } \\
\text { (natural; not } \\
\text { considered as } \\
\text { a factor) }\end{array}$ & $\begin{array}{l}\text { Alexandrium catenella } \\
\text { (=A. fundyense as } \\
\text { refered to in this } \\
\text { study }{ }^{*} \\
\text { Simulated bloom; } \\
3 \times 10^{3} \text { cells } \mathrm{mL}^{-1} \text { every } \\
90 \mathrm{~min} ; 9 \text { days. }\end{array}$ & Prevalence $(\uparrow)$ & $\begin{array}{l}\text { Viability; } \\
\text { Histopathology; } \\
\text { Circulating hem.; } \\
\text { Toxin } \\
\text { accumulation; } \\
\text { Pathogen infection }\end{array}$ & $\begin{array}{l}\text { Effect of HAB for all infection } \\
\text { status: } \\
\text { - Inflammatory response: hem. } \\
\text { infiltration in gonad, and stomach } \\
\text { and intestine lumen, circulating } \\
\text { hem. modulations. } \\
\text { - Mucus secretory cells in gills } \\
\text { - Oxidative stress: ceroidosis in } \\
\text { tissues }\end{array}$ & $\begin{array}{l}\text { Immunosuppression } \\
\text { caused by HAB } \\
\text { exposure }\end{array}$ & $\begin{array}{l}\text { (Galimany } \\
\text { et al., } \\
\text { 2008b) }\end{array}$ \\
\hline $\begin{array}{l}\text { Perna perna; } \\
\text { adults }\end{array}$ & $\begin{array}{l}\text { RLO, } \\
\text { copepods } \\
\text { (Cop.), } \\
\text { Nematopsis } \\
\text { sp. (Nem.), } \\
\text { Trematodes } \\
\text { (Trem.), } \\
\text { Tylocephalum } \\
\text { sp. (Tyl.); } \\
\text { (natural; not } \\
\text { considered as } \\
\text { a factor) }\end{array}$ & $\begin{array}{l}\text { Prorocentrum lima } \\
\text { Simulated bloom; } \\
9 \times 10^{2} \text { cells } \mathrm{mL}^{-1} \text { once a } \\
\text { day; } 1,2 \& 4 \text { days. }\end{array}$ & $\begin{array}{l}\text { RLO, Cop.: } \\
\text { Prevalence }(\downarrow) \\
\text { Others: } \\
\text { Prevalence (=) }\end{array}$ & $\begin{array}{l}\text { Survival; Shell- } \\
\text { valve closure } \\
\text { response; } \\
\text { Circulating hem.; } \\
\text { Histopathology } \\
\text { (incl. pathogen } \\
\text { infection) }\end{array}$ & $\begin{array}{l}\text { Effect of HAB for all infection } \\
\text { status: } \\
\text { - Alteration of shell valve-closure } \\
\text { response } \\
\text { - Circulating hem. modulations } \\
\text { - In digestive gland, alteration } \\
\text { (atrophy of digestive tubules) and } \\
\text { inflammatory response (hem. } \\
\text { infiltrations) }\end{array}$ & NA & $\begin{array}{l}\text { (Neves et } \\
\text { al., 2019) }\end{array}$ \\
\hline
\end{tabular}




\begin{tabular}{|c|c|c|c|c|c|c|c|c|}
\hline $\begin{array}{l}\text { Ruditapes } \\
\text { philippinarum; } \\
\text { adult }\end{array}$ & $\begin{array}{l}\text { Perkinsus } \\
\text { olseni } \\
\text { (natural; } 2 \\
\text { classes of } \\
\text { infection: very } \\
\text { light-light } v s . \\
\text { moderate- } \\
\text { heavy) }\end{array}$ & $\begin{array}{l}\text { Alexandrium } \\
\text { ostenfeldii } \\
\text { Simulated bloom } ; 10^{3} \\
\text { cells mL } \mathrm{m}^{-1} \\
\text { continuously; } 7 \text { days }\end{array}$ & $\begin{array}{l}\text { Prevalence }(=) \text {; } \\
\text { Intensity (NS } \\
\text { trend } \downarrow \text { ) }\end{array}$ & NA & $\begin{array}{l}\text { Viability; Condition } \\
\text { index; Circulating } \\
\text { hem. and plasma; } \\
\text { Histopathology; } \\
\text { Activity of } \\
\text { antioxidant and } \\
\text { digestive enzymes; } \\
\text { Toxin } \\
\text { accumulation; } \\
\text { Pathogen infection }\end{array}$ & $\begin{array}{l}\text { Effect of HAB for all infection } \\
\text { status: } \\
\text { - Tissue alterations in digestive } \\
\text { gland, gills and mantle } \\
\text { - Inflammatory response: hem. } \\
\text { infiltration in gills and digestive } \\
\text { gland, hem. diapedesis in digestive } \\
\text { gland epithelia, circulating hem. } \\
\text { modulations } \\
\text { - Metabolic and oxidative } \\
\text { processes: modulation of } \\
\text { antioxidant enzyme activity in gills } \\
\text { and hem. modulations } \\
\text { - Combined effect HAB - highest } \\
\text { infection class: } \\
\text { Antagonistic: Suppression of } \\
\text { anti/pro-oxidative responses to } \\
\text { highest parasite burden (CAT } \\
\text { activity in gills, ROS in hem.) }\end{array}$ & NA & $\begin{array}{l}\text { (Lassudrie } \\
\text { et al., } \\
2014)\end{array}$ \\
\hline $\begin{array}{l}\text { Ruditapes } \\
\text { philippinarum; } \\
\text { adults }\end{array}$ & $\begin{array}{l}\text { Perkinsus } \\
\text { olseni } \\
\text { (natural; } 2 \\
\text { classes of } \\
\text { infection: null- } \\
\text { light vs. } \\
\text { moderate- } \\
\text { heavy) }\end{array}$ & $\begin{array}{l}\text { Karenia selliformis } \\
\text { Bivalve exposure: } \\
\text { simulated bloom; } 10^{2} \text { - } \\
10^{3} \text { cells mL } \\
\text { continuously; } 6 \text { weeks. } \\
\text { Pathogen exposure: in } \\
\text { vitro, HAB whole } \\
\text { culture or exudates, cell } \\
\text { ratio } 1: 250 \\
\text { (HAB:pathogen); } 30 \\
\text { min, } 1 \text { h30, } 3 \text { h30. }\end{array}$ & $\begin{array}{l}\text { Prevalence and } \\
\text { intensity }(\downarrow) \\
\text { after } 2 \text { and } 3 \\
\text { weeks, and } \\
\text { recovery after } \\
\text { decrease of } \\
\text { HAB } \\
\text { concentration }\end{array}$ & $\begin{array}{l}\text { Mortality } \\
\text { (whole } \\
\text { culture; } \\
\text { exudates), } \\
\text { altered } \\
\text { morphology } \\
\text { (whole } \\
\text { culture) }\end{array}$ & $\begin{array}{l}\text { Viability; Condition } \\
\text { index; Circulating } \\
\text { hem. and plasma; } \\
\text { Pathogen infection }\end{array}$ & $\begin{array}{l}\text { Effect of HAB for all infection } \\
\text { Status } \\
\text { Circulating hem. modulations } \\
\text { Combined effect HAB-pathogen: } \\
\text { none }\end{array}$ & $\begin{array}{l}\text { Direct toxicity of } \\
\text { HAB to pathogen }\end{array}$ & $\begin{array}{l}\text { (da Silva et } \\
\text { al., 2008) }\end{array}$ \\
\hline $\begin{array}{l}\text { Ruditapes } \\
\text { philippinarum; } \\
\text { adults }\end{array}$ & $\begin{array}{l}\text { Perkinsus } \\
\text { olseni } \\
\text { (natural; } 2 \\
\text { classes of } \\
\text { infection: null- } \\
\text { light vs. } \\
\text { moderate- } \\
\text { heavy) }\end{array}$ & $\begin{array}{l}\text { Prorocentrum } \\
\text { minimum } \\
\text { Bivalve exposure: } \\
\text { simulated bloom; } 10^{5} \\
\text { cells } \mathrm{mL}^{-1} \\
\text { continuously; } 6 \text { days. } \\
\text { Pathogen exposure: in } \\
\text { vitro, HAB whole } \\
\text { culture or exudates, cell } \\
\text { ratio 1:50 } \\
\text { (HAB:pathogen); } 30 \\
\text { min }\end{array}$ & $\begin{array}{l}\text { Prevalence and } \\
\text { intensity }(=)\end{array}$ & $\begin{array}{l}\text { Mortality } \\
\text { and altered } \\
\text { morphology } \\
\text { (whole } \\
\text { culture; } \\
\text { exudates) }\end{array}$ & $\begin{array}{l}\text { Viability; Condition } \\
\text { index; Circulating } \\
\text { hem. and plasma; } \\
\text { Histopathology; } \\
\text { Apoptosis; } \\
\text { Pathogen infection }\end{array}$ & $\begin{array}{l}\text { Effect of HAB for all infection } \\
\text { status } \\
\text { - Condition index }(\downarrow) \\
\text { - Circulating hem. modulations } \\
\text { - Tissue alterations (adductor and } \\
\text { foot muscles, digestive gland, ova); } \\
\text { hem. infiltration in gonad; bacteria } \\
\text { and hem. (viable and apoptotic) in } \\
\text { intestine lumen. } \\
\text { Combined effect HAB-pathogen: } \\
\text { - Synergistic: Tissue degeneration } \\
\text { in gonad }\end{array}$ & NA & $\begin{array}{l}\text { (Hégaret et } \\
\text { al., 2009) }\end{array}$ \\
\hline
\end{tabular}




\begin{tabular}{|c|c|c|c|c|c|c|c|c|}
\hline $\begin{array}{l}\text { Ruditapes } \\
\text { philippinarum, } \\
\text { adults }\end{array}$ & $\begin{array}{l}\text { Perkinsus } \\
\text { olseni, } \\
\text { (natural, } 2 \\
\text { classes of } \\
\text { infection: null- } \\
\text { light } v \text { s. } \\
\text { moderate- } \\
\text { heavy) }\end{array}$ & $\begin{array}{l}\text { Karenia mikimotoi } \\
\text { (K.m.); Karenia } \\
\text { selliformis (K.s.) } \\
\text { Simulated bloom; K.m.: } \\
10^{3} \text { cells } \mathrm{mL}^{-1} ; \text { K.s.: } 5 \mathrm{x} \\
10^{2} \text { cells } \mathrm{mL}^{-1} ; \\
\text { continuously: } 3 \& 6 \\
\text { days }\end{array}$ & $\begin{array}{l}\text { Prevalence and } \\
\text { intensity (=) }\end{array}$ & $\mathrm{NA}$ & $\begin{array}{l}\text { Condition index; } \\
\text { Circulating hem.; } \\
\text { Plasma; Pathogen } \\
\text { infection; }\end{array}$ & $\begin{array}{l}\text { Effect of HAB for all infection } \\
\text { status: } \\
\text { Circulating hem. modulations, } \\
\text { stronger for K.s. than K.m. } \\
\text { Combined effect HAB-pathogen: } \\
\text { Synergistic effects: circulating hem. } \\
\text { modulations for K.s. after } 3 \text { days }\end{array}$ & NA & $\begin{array}{l}\text { (Hégaret et } \\
\text { al., 2007a) }\end{array}$ \\
\hline $\begin{array}{l}\text { Ruditapes } \\
\text { philippinarum; } \\
\text { juveniles } \\
(J u v .) ; \text { adults } \\
(\text { Ad. })\end{array}$ & $\begin{array}{l}\text { Vibrio tapetis } \\
\text { (Juv.: } \\
\text { experimental } \\
\text { by injection; } \\
\text { Ad.: natural, } 4 \\
\text { stages) }\end{array}$ & $\begin{array}{l}\text { Alexandrium catenella } \\
\text { (named } A \text {. tamarense in } \\
\text { this study)* } \\
\text { Simulated bloom. Juv.: } \\
5 \times 10^{1} \text { cells } \mathrm{mL}^{-1} \\
\text { continuously; } 3 \text { days. } \\
\text { Ad.: } 10^{2} \text { cells } \mathrm{mL}^{-1} \\
\text { continuously; } 16 \mathrm{~h} .\end{array}$ & $\begin{array}{l}\text { Juv.: Apparent } \\
\text { prevalence and } \\
\text { intensity }(\downarrow) \\
\text { (assessed by } \\
\text { shell mark } \\
\text { symptoms). } \\
\text { Ad.: None }\end{array}$ & NA & $\begin{array}{l}J u v . \& \text { Ad.: } \\
\text { Viability; } \\
\text { Burrowing; Toxin } \\
\text { accumulation; } \\
\text { Disease stage } \\
\text { (based on shell- } \\
\text { mark symptoms); } \\
\text { Juv.: Growth; Ad.: } \\
\text { Condition index, } \\
\text { Circulating hem. }\end{array}$ & $\begin{array}{l}\text { Effect of HAB., all infection status: } \\
J u v: \text { Viability }(\downarrow) \text {; Burrowing } \\
\text { incapacitation; Growth }(\downarrow) \text {; } \\
\text { Ad.: Burrowing incapacitation; } \\
\text { Circulating hem. modulations } \\
\text { Combined effect HAB-pathogen: } \\
\text { Juv.: Cumulative: Higher mortality }\end{array}$ & $\begin{array}{l}J u v .: \text { Unclear if } \\
\text { apparent decrease } \\
\text { of disease severity } \\
\text { traduces host- } \\
\text { pathogen } \\
\text { modulation, or a } \\
\text { decrease of defense } \\
\text { mechanisms } \\
\text { (possibly related to } \\
\text { shell mark } \\
\text { symptoms) }\end{array}$ & $\begin{array}{l}\text { (Bricelj et } \\
\text { al., 2011) }\end{array}$ \\
\hline $\begin{array}{l}\text { Mercenaria } \\
\text { mercenaria; } \\
\text { adults }\end{array}$ & $\begin{array}{l}\text { QPX (natural; } \\
\text { infected } v s \text {. } \\
\text { non infected) }\end{array}$ & $\begin{array}{l}\text { Prorocentrum } \\
\text { minimum } \\
\text { Simulated bloom; } \\
2 \times 10^{4} \text { cells } \mathrm{mL}^{-1} \\
\text { continuously; } 5 \text { days. }\end{array}$ & NA & NA & $\begin{array}{l}\text { Viability; } \\
\text { Circulating hem. } \\
\text { and plasma; } \\
\text { Histopathology; } \\
\text { Pathogen infection }\end{array}$ & $\begin{array}{l}\text { Effect of HAB in non-infected } \\
\text { bivalves: } \\
\text { - Circulating hem. modulations } \\
\text { - Tissue alteration and } \\
\text { inflammatory response (hem. } \\
\text { infiltrations) in gills, hemocytic } \\
\text { aggregates in all organs } \\
\text { Effect of HAB in infected bivalves: } \\
\text { - Circulating hem.: morphology } \\
\text { - Hem. infiltrations in tissues }\end{array}$ & NA & $\begin{array}{l}\text { (Hégaret et } \\
\text { al., 2010) }\end{array}$ \\
\hline $\begin{array}{l}\text { Argopecten } \\
\text { purpuratus, } \\
\text { adults }\end{array}$ & $\begin{array}{l}\text { RLO, (natural; } \\
\text { not considered } \\
\text { as a factor) }\end{array}$ & $\begin{array}{l}\text { Alexandrium } \\
\text { catenella* } \\
\text { Simulated bloom; } \\
5 \times 10^{3} \text { cells } \mathrm{mL}^{-1} \\
\text { continuously; } 6 \text { days }\end{array}$ & Prevalence $(\uparrow)$ & NA & $\begin{array}{l}\text { Survival; Escape } \\
\text { response, Heat- } \\
\text { shock protein } \\
\text { (hsp70); } \\
\text { Histopathology } \\
\text { (incl. pathogen } \\
\text { infection); Toxin } \\
\text { accumulation }\end{array}$ & $\begin{array}{l}\text { Effect of HAB for all infection } \\
\text { status: } \\
\text { - Altered escape response to } \\
\text { predator } \\
\text { - Tissue alteration in muscle } \\
\text { - Melanization of epithelia }\end{array}$ & $\begin{array}{l}\text { Physiological } \\
\text { weakness and } \\
\text { decreased defense } \\
\text { associated to } \\
\text { pathologies caused } \\
\text { by HAB }\end{array}$ & $\begin{array}{l}\text { (Hégaret et } \\
\text { al., 2012) }\end{array}$ \\
\hline
\end{tabular}

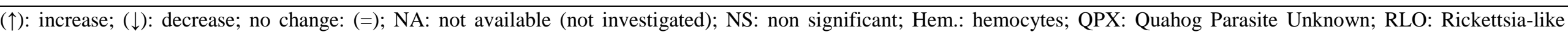

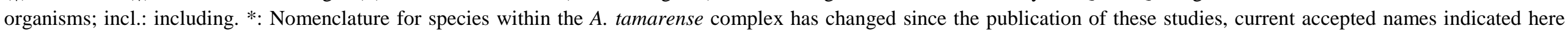
were deduced from John et al. (2014); Fraga et al. (2015); Litaker et al. (2018), where A. catenella corresponds to group I, A. tamarense to group III, A. pacificum to group IV). 
Table 4. Literature survey of most recently reported effects of marine harmful algae blooms (HABs) combined with pathogen infection on bivalve hemocyte variables involved in cellular immunity.

\begin{tabular}{|c|c|c|c|c|c|c|}
\hline $\begin{array}{l}\text { Bivalve } \\
\text { species }\end{array}$ & Pathogen & HAB species & Experiment type & Effects of HABs and pathogens on hemocytes & $\begin{array}{l}\text { Effect of HAB on pathogen } \\
\text { infection }(\mathrm{h}: \text { considered to } \\
\text { be related to hemocytes })\end{array}$ & Reference \\
\hline $\begin{array}{l}\text { Ruditapes } \\
\text { philippinarum }\end{array}$ & $\begin{array}{l}\text { Perkinsus } \\
\text { olseni }\end{array}$ & $\begin{array}{l}\text { Karenia } \\
\text { mikimotoi } \\
(\text { K.m. }) \\
\text { Karenia } \\
\text { selliformis } \\
(\text { K.s. })\end{array}$ & $\begin{array}{l}\text { Simulated bloom } \\
\text { K.m.: } 10^{3} \text { cells } \mathrm{mL}^{-1} \\
K . s .: 5 \times 10^{2} \text { cells } \mathrm{mL}^{-1} \\
\text { for } 3 \text { and } 6 \text { days. }\end{array}$ & $\begin{array}{l}\text { Effect of HAB: viability }(\uparrow, K . s ., K . m .), \text { size and complexity }(\downarrow, \\
\text { K.s. }) \text {, phagocytosis }(=) \text {, ROS }(=) \text {, agglutination titer }(=) . \\
\text { Effect of parasite: all parameters }(=) \text {. } \\
\frac{\text { Combined effect: }}{\text { (after } 3 \text { days). }}\end{array}$ & Prevalence (=), intensity $(=)$. & $\begin{array}{l}\text { (Hégaret } \\
\text { et al., } \\
\text { 2007a) }\end{array}$ \\
\hline $\begin{array}{l}\text { Ruditapes } \\
\text { philippinarum }\end{array}$ & $\begin{array}{l}\text { Perkinsus } \\
\text { olseni }\end{array}$ & $\begin{array}{l}\text { Prorocentrum } \\
\text { minimum }\end{array}$ & $\begin{array}{l}\text { Simulated bloom } \\
10^{3} \text { cells } \mathrm{mL}^{-1} \text {, for } 6 \\
\text { days. } \\
\text { In vitro } \\
\text { P. minimum - P. olseni } \\
-(1: 500)\end{array}$ & $\begin{array}{l}\text { Effect of HAB: THC }(=) \text {, size }(\downarrow) \text {, complexity }(=) \text {, viability }(=) \text {, } \\
\text { phagocytosis }(\downarrow), \text { ROS }(=) \text {, agglutination titter }(=) \text {. } \\
\text { Effect of parasite: all parameters }(=) \text {. } \\
\text { Combined effect: none }\end{array}$ & Prevalence (=), intensity (=). & $\begin{array}{l}\text { (Hégaret } \\
\text { et al., } \\
2009)\end{array}$ \\
\hline $\begin{array}{l}\text { Ruditapes } \\
\text { philippinarum }\end{array}$ & $\begin{array}{l}\text { Perkinsus } \\
\text { olseni }\end{array}$ & $\begin{array}{l}\text { Alexandrium } \\
\text { ostenfeldii }\end{array}$ & $\begin{array}{l}\text { Simulated bloom } \\
10^{3} \text { cells } \mathrm{mL}^{-1} \text {, for } 7 \\
\text { days. }\end{array}$ & 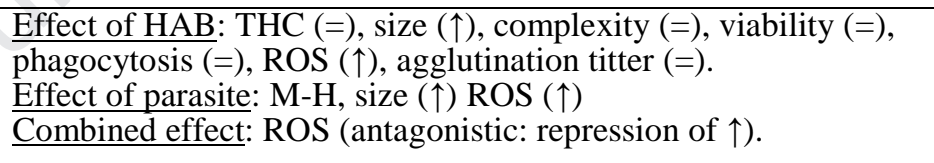 & $\begin{array}{l}\text { Intensity of infection ( } \downarrow \text { non- } \\
\text { significant) }\end{array}$ & $\begin{array}{l}\text { (Lassudrie } \\
\text { et al., } \\
2014)\end{array}$ \\
\hline $\begin{array}{l}\text { Crassostrea } \\
\text { virginica }\end{array}$ & $\begin{array}{l}\text { Perkinsus } \\
\text { marinus } \\
(\text { P.m. }) \\
\text { Bucephalus } \\
\text { sp. (B.) }\end{array}$ & $\begin{array}{l}\text { Alexandrium } \\
\text { catenella }(=A \text {. } \\
\text { fundyense as } \\
\text { refered to in } \\
\text { this study)* }\end{array}$ & $\begin{array}{l}\text { Simulated bloom } \\
1-2 \times 10^{3} \text { cells } \mathrm{mL}^{-1} \\
\text { for } 3 \text { weeks. }\end{array}$ & $\begin{array}{l}\text { Effect of HAB: THC }(=) \text {, size }(=) \text { and complexity }(=), \text { ROS }(=) \text {. } \\
\text { Effect of } B .: \text { THC }(\uparrow) \text {, viability }(\uparrow) \text {. } \\
\text { Effect of } P . m .: \text { all parameters }(=) \text {. } \\
\text { Combined effect HAB- } B \text { : THC (repression of } \uparrow \text { normally induced } \\
\text { by } B .)\end{array}$ & $\begin{array}{l}\text { Prevalence of } P . m . \\
\text { infected oysters }\end{array}$ & $\begin{array}{l}\text { (Lassudrie } \\
\text { et al., } \\
\text { 2015a) }\end{array}$ \\
\hline $\begin{array}{l}\text { Mercenaria } \\
\text { mercenaria }\end{array}$ & QPX & $\begin{array}{l}\text { Prorocentrum } \\
\text { minimum }\end{array}$ & $\begin{array}{l}\text { Simulated bloom } \\
2 \times 10^{4} \text { cells } \mathrm{mL}^{-1} \text {, for } 5 \\
\text { days. }\end{array}$ & $\begin{array}{l}\text { Effect of HAB: THC }(=) \text {, size }(\uparrow) \text {, complexity }(=) \text {, viability }(=) \text {, } \\
\text { phagocytosis }(\downarrow), \text { ROS }(\uparrow) \text {, adhesion }(=) \text {, apoptosis }(=) \text {. } \\
\text { Combined effect: phagocytosis }(\downarrow) \text {, size }(\downarrow) \text {. }\end{array}$ & NA & $\begin{array}{l}\text { (Hégaret } \\
\text { et al., } \\
2010)\end{array}$ \\
\hline
\end{tabular}




\begin{tabular}{|c|c|c|c|c|c|}
\hline Mytilus edulis & $\begin{array}{l}\text { Gymnophalli } \\
\text { dae } \\
\text { trematode }\end{array}$ & $\begin{array}{l}\text { Alexandrium } \\
\text { catenella }(=A . \\
\text { fundyense as } \\
\text { refered to in } \\
\text { this study)* }\end{array}$ & $\begin{array}{l}\text { Simulated bloom } \\
4 \times 10^{3} \text { cells } \mathrm{mL}^{-1} \text {, for } 9 \\
\text { days. }\end{array}$ & $\begin{array}{l}\text { Effect of HAB: THC }(\downarrow), \text { GRC }(\downarrow) \text {, phagocytosis }(=) \text {, ROS }(=) \text {, } \\
\text { complexity ( } \downarrow \text {, GR and HY), size (GR } \downarrow, \text { HY }=) \text {. } \\
\text { Combined effect: none }\end{array}$ & $\begin{array}{l}\text { (Galimany } \\
\text { et al., } \\
\text { 2008b) }\end{array}$ \\
\hline
\end{tabular}


Table 3. Literature survey of most recently reported effects of marine harmful algal blooms (HABs) or their toxins on bivalve hemocyte variables involved in cellular immunity.

\begin{tabular}{|c|c|c|c|c|}
\hline Bivalve species & HAB/phycotoxin & Experiment type & Hemocyte parameters & Reference \\
\hline Mytilus chilensis & Saxitoxins & $\begin{array}{l}\text { In vitro } \\
1-100 \mathrm{nM}, 4 \mathrm{~h} \text { and } 16 \mathrm{~h} .\end{array}$ & Viability (=), ROS ( $\downarrow 10 \mathrm{nM}, \uparrow 100 \mathrm{nM})$, phagocytosis $(\downarrow)$ & $\begin{array}{l}\text { (Astuya et al., } \\
2015)\end{array}$ \\
\hline Crassostrea gigas & Saxitoxins & $\begin{array}{l}\text { In vitro } \\
0.8,1 \text { and } 3.3 \mu \mathrm{M}, 3.5 \mathrm{~h} \text {. }\end{array}$ & Apoptosis $(\uparrow)$. & $\begin{array}{l}\text { (Abi-Khalil et } \\
\text { al., 2017) }\end{array}$ \\
\hline $\begin{array}{l}\text { Crassostrea gigas }(C . g .) \\
\text { Chlamys farreri }(C . f .)\end{array}$ & Saxitoxins & $\begin{array}{l}\text { Injection } \\
10-20 \mu \mathrm{g} \text { STX eq. } 100 \mathrm{~g}^{-1} \text { shellfish meat, } \\
12,48 \text {, and } 96 \mathrm{~h} \text { p.i. }\end{array}$ & $\begin{array}{l}\text { Phagocytosis ( } \downarrow 12 \text { and 96h, C.g. and C.f.), ROS ( } \uparrow 48 \mathrm{~h} \text { and 96h, } \\
\text { C.f.). }\end{array}$ & $\begin{array}{l}\text { (Cao et al., } \\
\text { 2018) }\end{array}$ \\
\hline Crassostrea gigas & $\begin{array}{l}\text { Alexandrium minutum } \\
\text { (A.m.); } \\
\text { Saxitoxins }(S T X)\end{array}$ & $\begin{array}{l}\text { In vitro } \\
\text { A.m: } 2 \times 10^{4} \text { cells } \mathrm{mL}^{-1} \\
\text { STX: } 0.05 \mu \mathrm{g} \mathrm{L}^{-1} \text { for } 4 \mathrm{~h} \text {. }\end{array}$ & $\begin{array}{l}\text { Size }(\uparrow \text { GR, A.m. }) \text {, and complexity (=), viability (=), phagocytosis } \\
(\downarrow), \operatorname{ROS}(\downarrow) \text { for } A . m \text { and } S T X\end{array}$ & $\begin{array}{l}\text { (Mello et al., } \\
\text { 2013) }\end{array}$ \\
\hline $\begin{array}{l}\text { Crassostrea gigas (diploid } \\
\text { and triploid, in April and } \\
\text { in May) }\end{array}$ & Alexandrium minutum & $\begin{array}{l}\text { Simulated bloom } \\
5 \times 10^{3} \text { cells } \mathrm{mL}^{-1} \text {, for } 4 \text { days. }\end{array}$ & $\begin{array}{l}\text { THC }(\uparrow) \text { GRC }(\uparrow) \text {, viability }(=) \text {, phagocytosis }(=) \text {, ROS }(\uparrow \text { April } \\
\text { GR, } \downarrow \text { May GR and HY), agglutination titer }(=) \text {, phenoloxidase }(\downarrow \\
\text { April, } \uparrow \text { May). }\end{array}$ & $\begin{array}{l}\text { (Haberkorn et } \\
\text { al., 2010a) }\end{array}$ \\
\hline Crassostrea gigas & Alexandrium minutum & $\begin{array}{l}\text { Simulated bloom } \\
5 \times 10^{3} \text { cells } \mathrm{mL}^{-1} \text {, flow of } 14 \mathrm{~mL} \mathrm{~min}^{-1} \text {, for } \\
4 \text { days. }\end{array}$ & THC $(=)$, phagocytosis $(\uparrow), \operatorname{ROS}(=)$, phenoloxidase $(=)$ & $\begin{array}{l}\text { (Haberkorn et } \\
\text { al., 2014) }\end{array}$ \\
\hline Crassostrea gigas & $\begin{array}{l}\text { Alexandrium minutum } \\
\text { (PST, BEC, and } \\
\text { PST+BEC strains) }\end{array}$ & $\begin{array}{l}\text { Simulated bloom } \\
3.1 \times 10^{3} \text { cells } \mathrm{mL}^{-1} \text {, for } 4 \text { days (no control } \\
\text { algae). }\end{array}$ & $\begin{array}{l}\text { THC (=), HYC (PST < PST+BEC, BEC), Size (=), complexity } \\
(=) \text {, viability (PST < PST+BEC, BEC), phagocytosis (=), ROS (=). }\end{array}$ & $\begin{array}{l}\text { (Castrec et al., } \\
2018)\end{array}$ \\
\hline $\begin{array}{l}\text { Crassostrea gigas } \\
\text { (juveniles) }\end{array}$ & $\begin{array}{l}\text { Alexandrium pacificum } \\
\text { (named } \text {. catenella in } \\
\text { this study)* }\end{array}$ & $\begin{array}{l}\text { Simulated bloom } \\
10^{2} \text { cells } \mathrm{mL}^{-1} \text {, for } 4 \text { to } 9 \text { days. }\end{array}$ & $\begin{array}{l}\text { THC }(\uparrow), \text { GRC }(\uparrow), \text { HYC }(\uparrow), \text { size }(\uparrow \mathrm{HY}, \uparrow \text { GR day } 4), \text { complexity } \\
(\uparrow \mathrm{HY}, \uparrow \mathrm{GR}), \text { viability }(=), \operatorname{ROS}(\uparrow) .\end{array}$ & $\begin{array}{l}\text { (Lassudrie et al., } \\
\text { 2016) }\end{array}$ \\
\hline $\begin{array}{l}\text { Ruditapes philippinarum, } \\
\text { Mya arenaria }\end{array}$ & $\begin{array}{l}\text { Alexandrium catenella } \\
\text { (named A. tamarense in } \\
\text { this study)* (PST) } \\
\text { Alexandrium } \\
\text { tamarense (nonPST) }\end{array}$ & $\begin{array}{l}\text { In vitro } \\
\text { Filtered extracts of } 5 \times 10^{5} \text { cells } \mathrm{mL}^{-1}\end{array}$ & Adherence ( $\downarrow$ nonPST), phagocytosis ( $\downarrow$ nonPST). & $\begin{array}{l}\text { (Ford et al., } \\
\text { 2008) }\end{array}$ \\
\hline Mytilus edulis & $\begin{array}{l}\text { Alexandrium catenella } \\
\text { (PST and PST }+\mathrm{LC} \\
\text { strains) } \\
\text { A.tamarense (LC } \\
\text { strain) }\end{array}$ & $\begin{array}{l}\text { Simulated bloom } \\
500 \text { cells } \mathrm{mL}^{-1} \text {, for } 3 \text { and } 7 \text { days. }\end{array}$ & $\begin{array}{l}\text { THC ( } \downarrow \text { PST and LC, = PST+LC, } 3 \text { days ; = PST, PST+LC and } \\
\text { LC, } 7 \text { days), viability and lysosomal membrane stability ( } \downarrow \text { for all, } \\
3 \text { and } 7 \text { days), phagocytosis ( } \uparrow \text { PST, } 3 \text { days } ;=\text { for all, } 7 \text { days), } \\
\text { ROS ( } \downarrow \text { for all, } 3 \text { days). }\end{array}$ & $\begin{array}{l}\text { (Bianchi et al., } \\
\text { 2019) }\end{array}$ \\
\hline
\end{tabular}




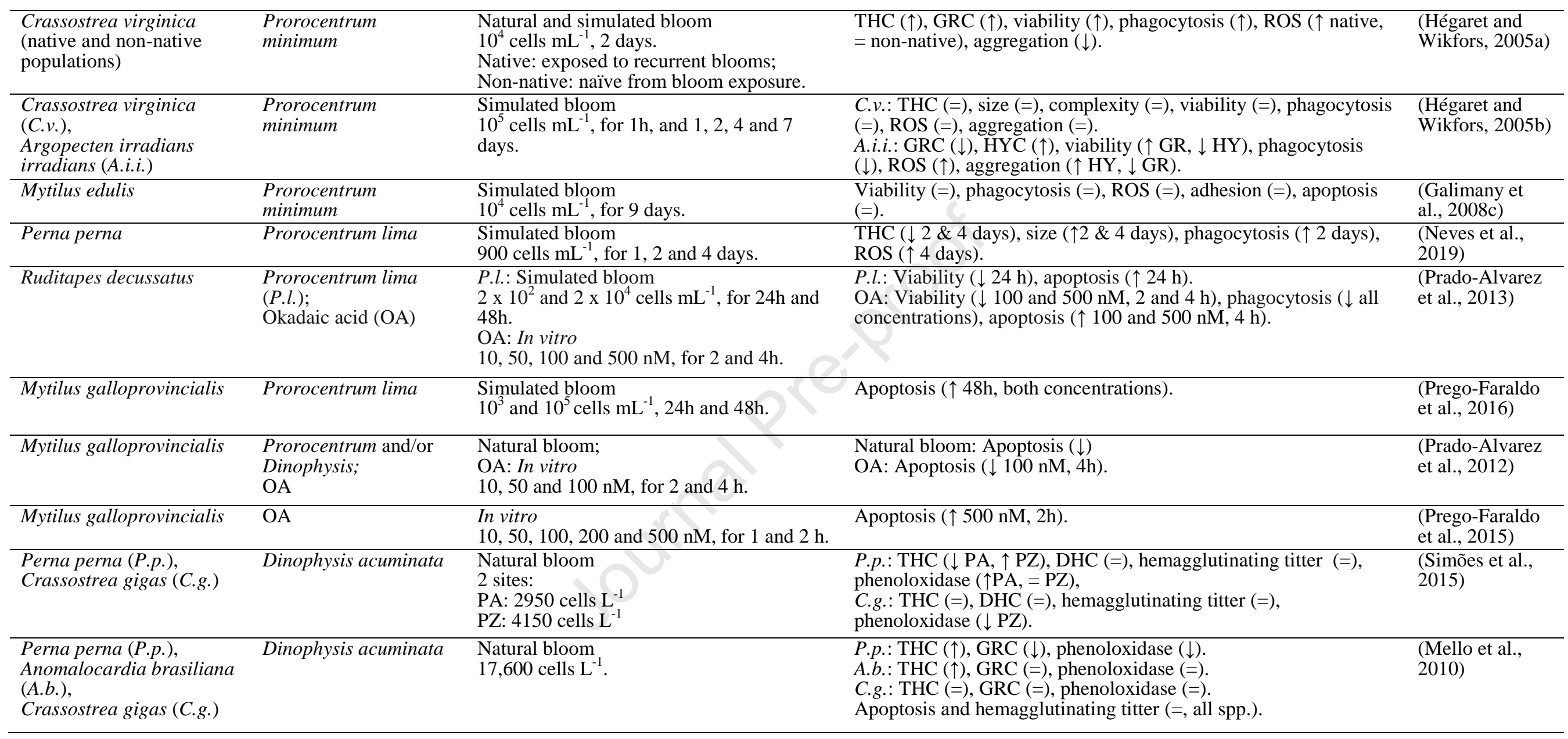




\begin{tabular}{|c|c|c|c|c|}
\hline $\begin{array}{l}\text { Mercenaria mercenaria } \\
\text { (M.m.), } \\
\text { Mya arenaria (M.a.), } \\
\text { Crassostrea virginica } \\
\text { (C.v.), } \\
\text { Crassostrea gigas }(\text { C.g.), } \\
\text { Ruditapes philippinarum } \\
\text { (R.p.) }\end{array}$ & $\begin{array}{l}\text { Heterosigma akashiwo } \\
\text { (H.a.) } \\
\text { Prorocentrum } \\
\text { minimum (P.m.) } \\
\text { Alexandrium catenella } \\
(=\text { A. fundyense as } \\
\text { refered in this study) } \\
(\text { Ac. }) \\
\text { Alexandrium minutum } \\
(\text { A.m. }) \\
\text { Karenia selliformis } \\
(\text { K.s.) } \\
\text { Karenia mikimotoi } \\
(\text { K.m. })\end{array}$ & $\begin{array}{l}\text { In vitro } \\
\text { H.a.: } 10^{5} \text { cells } \mathrm{mL}^{-1} \\
\text { P.m.: } 10^{5} \text { cells } \mathrm{mL}^{-1} \\
\text { A.c.: } 10^{4} \text { cells } \mathrm{mL}^{-1} \\
\text { A.m.: } 5 \times 10^{4} \text { cells } \mathrm{mL}^{-1} \\
\text { K.s.: } 4-7 \times 10^{3} \text { cells } \mathrm{mL}^{-1} \\
\text { K.m.: } 4-7 \times 10^{3} \text { cells } \mathrm{mL}^{-1} \\
\text { For } 4 \mathrm{~h}\end{array}$ & 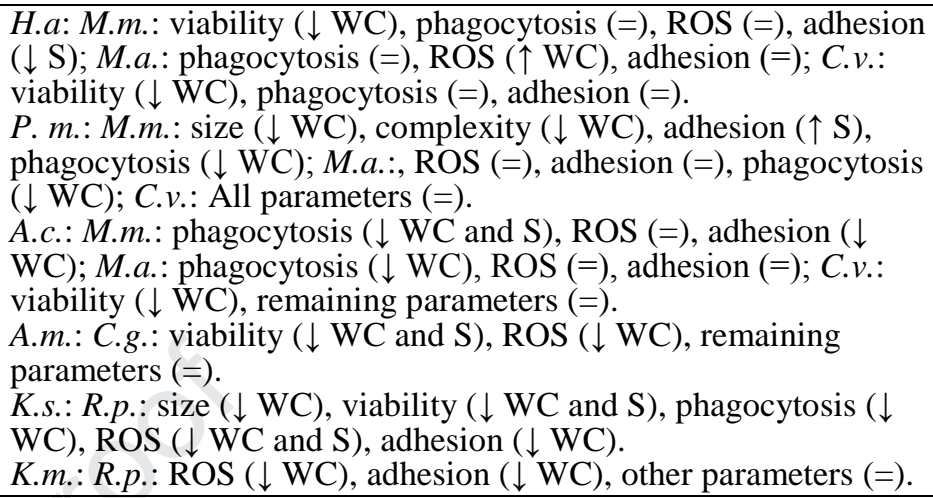 & $\begin{array}{l}\text { (Hégaret et al., } \\
\text { 2011) }\end{array}$ \\
\hline Crassostrea gigas & Brevetoxin & $\begin{array}{l}\text { In vitro } \\
3,30,100,300 \text { and } 1000 \mu \mathrm{g} \mathrm{L}^{-1} \text {, for } 1,4 \\
\text { and } 12 \mathrm{~h} \text {. }\end{array}$ & Viability $(=)$, apoptosis $(=)$ & $\begin{array}{l}\text { (Mello et al., } \\
\text { 2012) }\end{array}$ \\
\hline Mytilus galloprovincialis & Ostreopsis cf. ovata & $\begin{array}{l}\text { Simulated bloom } \\
1 \times 10^{5} \text { cells L } \mathrm{L}^{-1} \text {, for } 7 \text { and } 14 \text { days. }\end{array}$ & $\begin{array}{l}\text { GRC }(\downarrow), \text { HYC }(\uparrow) \text {, phagocytosis }(\downarrow) \text {, lysosomal membrane } \\
\text { stability }(\downarrow) \text {, for both durations. }\end{array}$ & $\begin{array}{l}\text { (Gorbi et al., } \\
2013 \text { ) }\end{array}$ \\
\hline Mytilus edulis & Domoic acid & $\begin{array}{l}\text { Injection } \\
1,10,100 \text { and } 500 \mathrm{ng} \text { g body weight }{ }^{-1}, 48 \mathrm{~h} \\
\text { and } 7 \text { days p.i. }\end{array}$ & $\begin{array}{l}\text { THC }(\uparrow 48 \mathrm{~h}, 500 \mathrm{ng}), \text { viability (all concentrations: }=48 \mathrm{~h} ; \uparrow 7 \\
\text { days), phagocytosis }(\uparrow 48 \mathrm{~h}, 100 \mathrm{ng}) .\end{array}$ & $\begin{array}{l}\text { (Dizer et al., } \\
\text { 2001) }\end{array}$ \\
\hline Ruditapes philippinarum & $\begin{array}{l}\text { Heterocapsa } \\
\text { circularisquama }\end{array}$ & $\begin{array}{l}\text { Simulated bloom } \\
10^{3} \text { cells } \mathrm{mL}^{-1}, \text { for } 24 \text { and } 48 \mathrm{~h} .\end{array}$ & $\mathrm{THC}(\uparrow 24 \mathrm{~h})$. & $\begin{array}{l}\text { (Basti et al., } \\
\text { 2011) }\end{array}$ \\
\hline Crassostrea gigas & $\begin{array}{l}\text { Alexandrium pacificum } \\
\text { (named A. catenella in } \\
\text { this study)* (PST) } \\
\text { Alexandrium } \\
\text { tamarense (nonPST) }\end{array}$ & $\begin{array}{l}\text { Simulated bloom, } \\
10^{3} \text { cells } \mathrm{mL}^{-1}, \text { for } 48 \mathrm{~h} .\end{array}$ & Apoptosis (PST>nonPST, 29h) & $\begin{array}{l}\text { (Medhioub et } \\
\text { al., 2013) }\end{array}$ \\
\hline Nodipecten subnodosus & Saxitoxins & $\begin{array}{l}\text { Injection: } \\
140 \mu \mathrm{g} \text { STX eq per } 0.2 \mathrm{~mL} \text { injection, } 24 \mathrm{~h} \\
\text { p.i. } \\
\text { In vitro: } \\
10-20 \mu \mathrm{g} \text { STX eq. } \mathrm{mL}^{-1}, 24 \mathrm{~h} \text { p.i. }\end{array}$ & Apoptosis $(\uparrow)$ & $\begin{array}{l}\text { (Estrada et al., } \\
\text { 2014) }\end{array}$ \\
\hline Nodipecten subnodosus & Saxitoxins & $\begin{array}{l}\text { Injection } \\
\text { Low dose: } 6.25 \mathrm{MU}, 0.2 \mathrm{~mL}, 12-72 \mathrm{~h} \text { p.i. } \\
\text { High dose: } 100 \mathrm{MU}, 0.2 \mathrm{~mL}, 40 \text { days p.i. }\end{array}$ & THC $(\downarrow)$ (low dose, 12 -24h p.i., high dose 10-40 days p.i.) & $\begin{array}{l}\text { (Estrada et al., } \\
2010)\end{array}$ \\
\hline Mytilus edulis & Karlodinium veneficum & $\begin{array}{l}\text { Simulated bloom } \\
6.25 \times 10^{1} \text { cells } \mathrm{mL}^{-1} \text {, for } 3 \text { and } 6 \text { days }\end{array}$ & $\begin{array}{l}\text { GRC ( } \downarrow 3 \text { days, }=6 \text { days), HYC }(\uparrow 3 \text { days, }=6 \text { days }), \text { ROS }(\uparrow), \\
\text { phagocytosis }(\uparrow 6 \text { days) }\end{array}$ & $\begin{array}{l}\text { (Galimany et } \\
\text { al., 2008a) }\end{array}$ \\
\hline
\end{tabular}

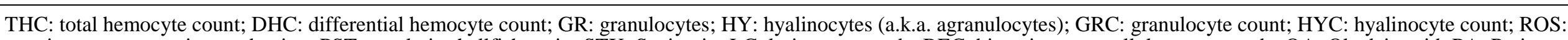
reactive oxygen species production; PST: paralytic shellfish toxin; STX: Saxitoxin; LC: lytic compounds; BEC: bioactive extracellular compounds; OA: Okadaic acid; PA: Praia

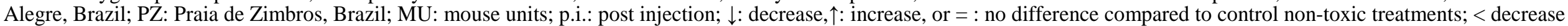




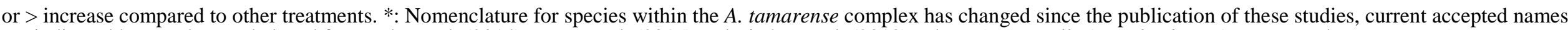

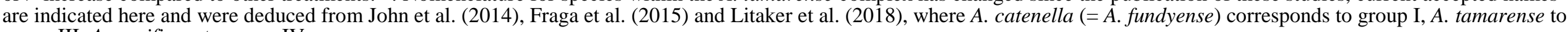
group III, A. pacificum to group IV. 
Figure 1

\section{HABs}

Toxins or bioactive extracellular compounds

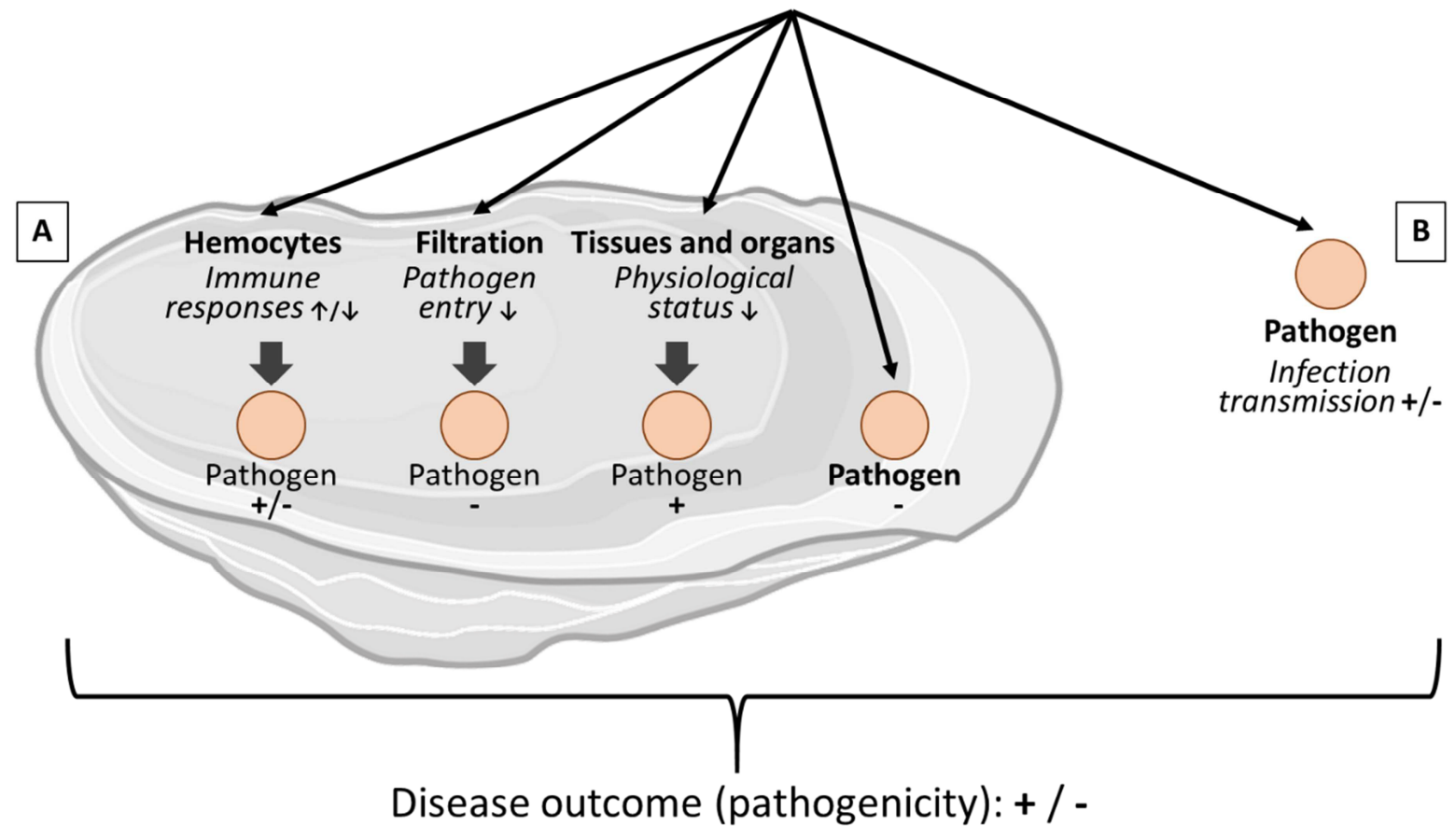


A Proposed long-term effect of $A$. pacificum on herpesvirus infection in oyster C. gigas (from Lassudrie et al., 2015a)

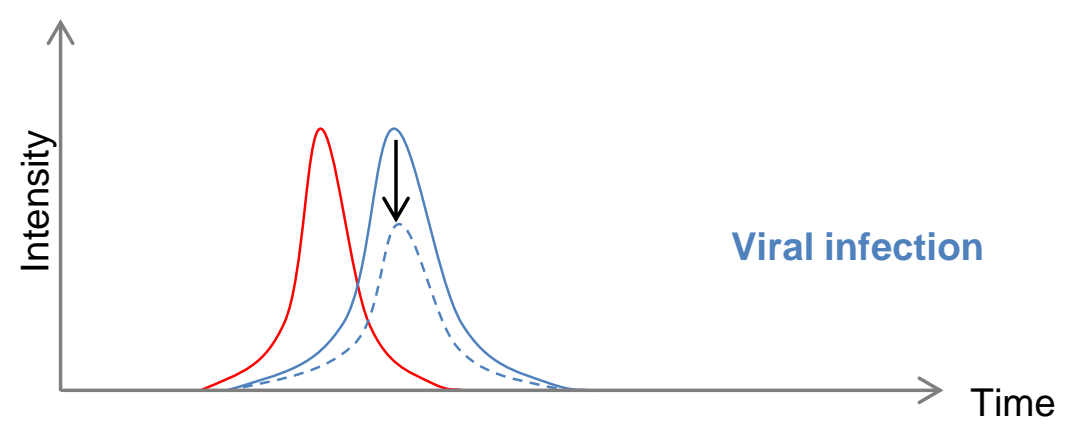

Proposed long-term effect of $A$. catenella ( $=A$. fundyense) on $P$. marinus infection in oyster $C$. virginica also infested with trematodes (from Lassudrie et al., 2015b)

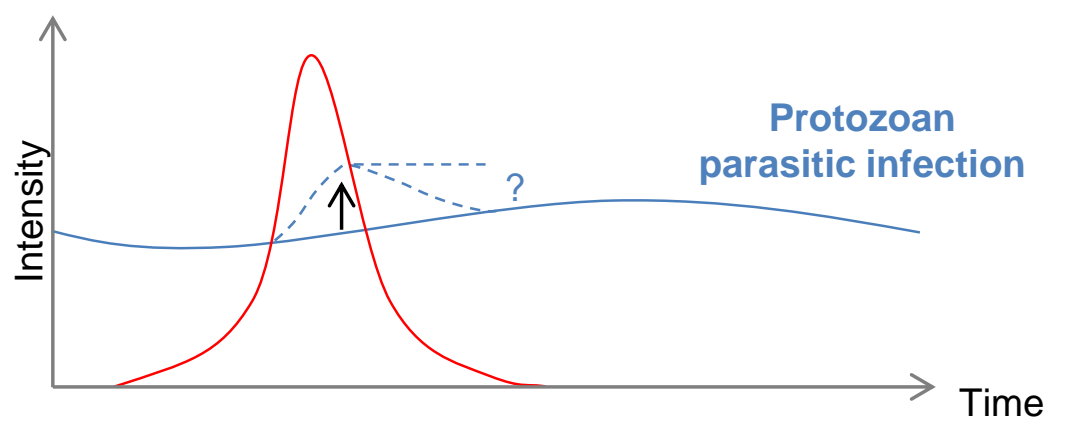

B Proposed long-term effect of $A$. pacificum on mortality related to $V$. tasmaniensis infection in oyster $C$. gigas

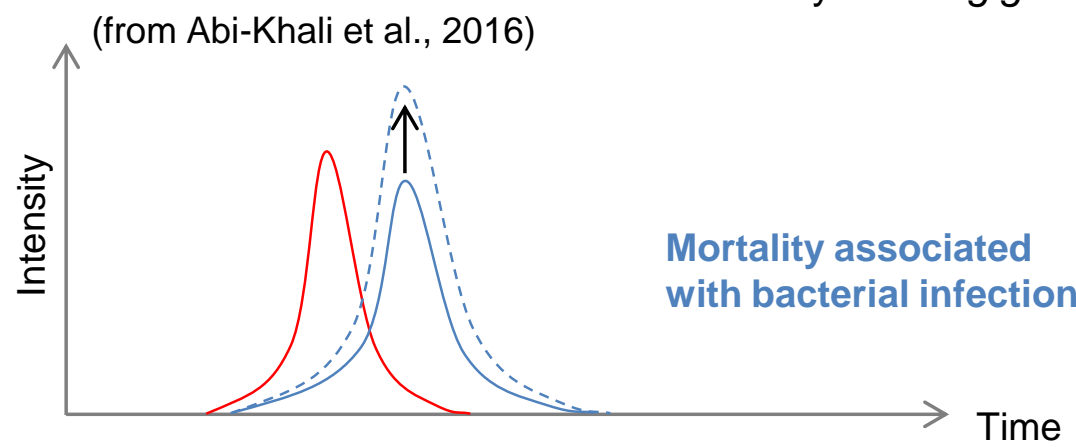

Proposed long-term effect of $K$. selliformis on $P$. olseni infection in clam R. philippinarum (from da Silva et al., 2008)

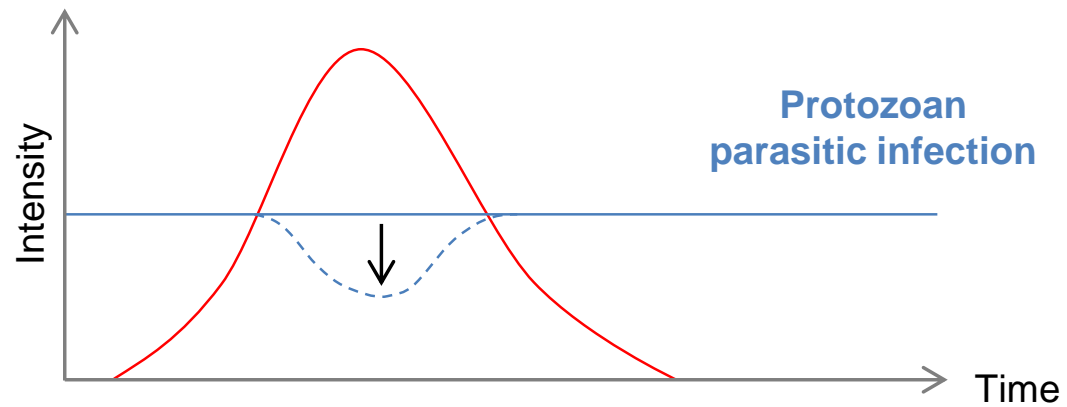

\begin{tabular}{ll|}
\hline & HAB \\
\hdashline & Pathogen infection or mortality, without HAB \\
$\downarrow \uparrow$ & Pathogen infection or mortality, under the effect of HAB \\
$\downarrow \uparrow$ & Effect of HAB
\end{tabular}




\section{Highlights}

- Review of the main studies on effects of marine harmful algae on bivalve immune cells (hemocytes) and on infectious disease

- Harmful algae can modulate host-pathogen interactions in bivalves on various way (increase or decrease the infection intensity or prevalence)

- Some experimental studies have reported the involvement of cellular immunity and global physiological weakness in these modulations

- Other mechanisms possibly involved include algal effects on bivalve filtration, and direct interaction of microalgae and their compounds with pathogens

- Future research should focus on field studies, at the population level, to establish the ecological and economical significance of the effects of harmful algal blooms on bivalve diseases 